\title{
In the Right (Wrong?) Place at The Right Time: A plausibility probe of Ziad Munson's process of mobilisation, with violent and non-violent evidence.
}

by

\section{Andrea Lane}

\author{
A thesis submitted to \\ the Faculty of Graduate and Postdoctoral Affairs \\ in partial fulfillment of the requirements for the degree of \\ Master of Arts \\ in
}

International Affairs

Carleton University

Ottawa, Ontario

@ 2014 Andrea Lane 


\begin{abstract}
This paper is a plausibility probe of Ziad Munson's theory of activist mobilisation, testing its relevance first to non-violent activist mobilisation and then to mobilisation into terroristic violence. As well, a case study of the Canadian terrorist group "Direct Action" is presented. Using both semi-structured interviews and extant research to provide data, Munson's mobilisation process was tested to determine if its further use, particularly by counterterrorism practitioners, is warranted. Munson's mobilisation process was found to be relevant to both non-violent activist mobilisation as well as mobilisation into political violence and terrorism. Suggestions are offered for further research.
\end{abstract}


Chapter 1: Introduction ....................................................................3

I. Why this research? .................................................................3

II. Why Munson's process...........................................................4

III. Research context....................................................................5

Chapter 2: Literature Review .....................................................12

I. Overview .............................................................................12

II. Network contacts and 'asking' ..............................................13

III. Biographical availability ........................................................17

IV. Life event or cognitive opening ............................................21

V. Psychology and Emotions ....................................................23

VI. Conclusion ..........................................................................24

Chapter 3: Munson's theoretical framework...................................26

I. Introduction...........................................................................26

II. Munson's Mobilisation Process.............................................29

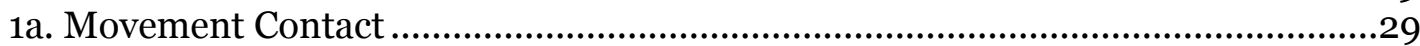

1b. Turning Points .....................................................................................................

2. Initial Activism ....................................................................................................

3. Development of Beliefs .......................................................................................32

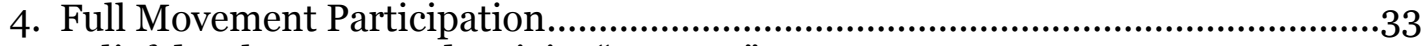

5. Belief development and activist "streams" ..............................................................33

III. Applicability to Terrorism Research ....................................36

Chapter 4: Methodology..................................................................37

I. Introduction .........................................................................37

II. Definitions used in the study ................................................38

III. Hypotheses to be tested .........................................................39

IV. Case selection .....................................................................39

1. Violent Case Studies..................................................................................................39

2. Non-violent Case Studies ......................................................................................41

V. Interview methodology .........................................................42

VI. Non-interview methodology ..................................................42

VII. Operationalization of Munson's Theory ..................................43

1. Turning Point ..........................................................................................................43

2. Movement Contact …………………………………………………………………4

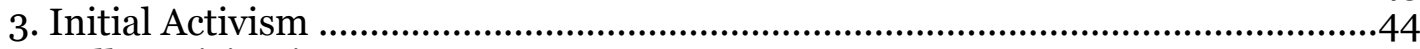

4. Full Participation ....................................................................................................44

VIII. Problems with the methodology ..........................................45

1. Small number of cases studied .............................................................................45

2. Problems inherent in interviews and autobiographies.............................................46

Chapter 5: 'Direct Action' ................................................................48

I. Why Direct Action? ...................................................................48

II. Direct Action: A timeline....................................................50

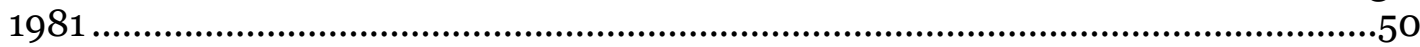

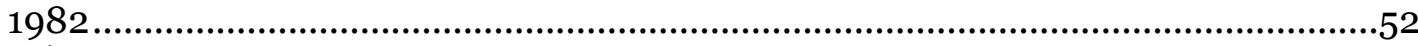

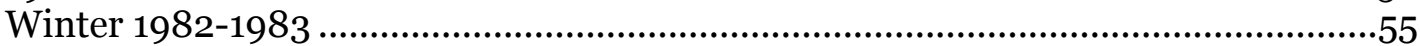

III. Direct Action In Context ......................................................56

IV. Actions Before Beliefs ..................................................61 
II. Violent case studies: 'Direct Action' ....................................64

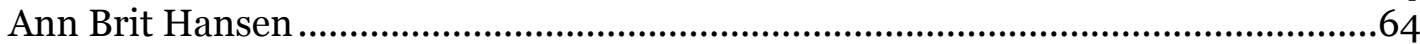

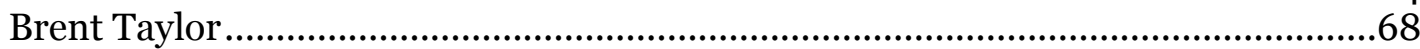

Juliet “Julie" Belmas..................................................................................................

Gerald “Gerry Useless" Hannah ....................................................................................74

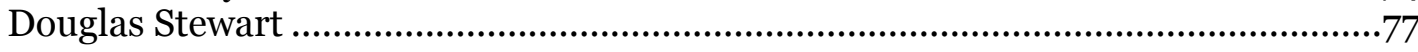

Chapter 6: Results .......................................................................79

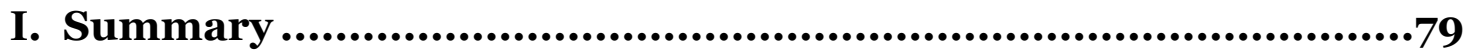

II. Hypotheses .............................................................................79

II. Information not accounted for by Munson's theory ..................80

1. Ideology ..........................................................................................................8

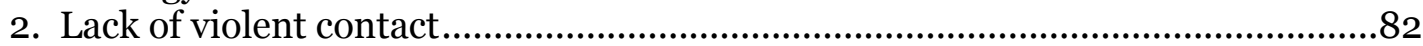

Chapter 7: Qualitative Results and Discussion...............................84

I. Non-violent cases ........................................................84

1. Turning Point.................................................................................................... 85

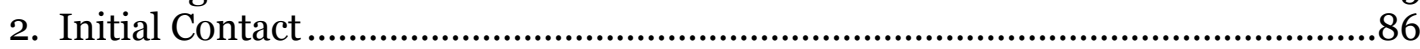

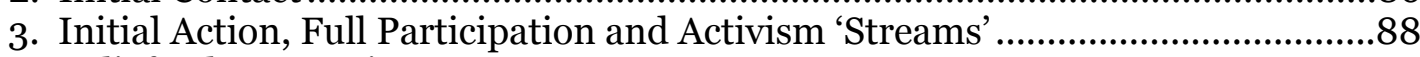

4. Beliefs About Tactics ................................................................................................91

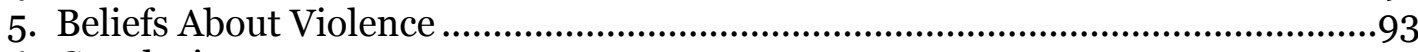

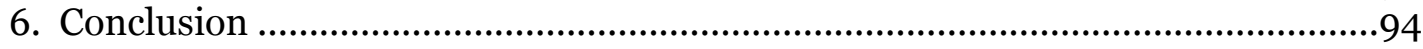

II. Violent Subjects ................................................................95

1. Turning Point ..........................................................................................................95

2. Initial Contact ………………………………………………………………98

3. Initial Action/Full Participation/Stream ................................................................99

Chapter 8: Recommendations and Conclusions .............................101

I. Further research .................................................................101

II. More effective use of counterterrorism resources ....................102

III. Better relationships with non-violent activists .....................105

IV. Conclusion ......................................................................111

Appendix 1: Interview Questionnaire ...........................................114

Appendix 2: List of Interviewees ................................................117

Appendix 3: List of sources for Violent case data............................118

Bibliography ...............................................................................120 


\section{Chapter 1: Introduction}

\section{Why this research?}

This research seeks to add to the academic understanding of micromobilisation into terroristic political violence: the individual-level process by which a person comes to embrace serious violence in the pursuit of a political or social cause. It will present a plausibility probe $^{1}$ of sociologist Ziad Munson's theory of activist mobilisation, and test its explanatory power in the case of differential activist recruitment into violence, that is, why some activists engaged with issues such as environmentalism or nuclear disarmament turn to terroristic violence, when others do not. In seeking a better understanding of terroristic violence within a social movement context, it is hoped this paper will illuminate how people come to use violence as a means of furthering their movement agendas. With a knowledge of who does (and, perhaps more importantly, who does not) incorporate terroristic violence into their activism tactics, counterterrorism (CT) and law enforcement practitioners can make more effective choices concerning the allocation of costly surveillance and investigation assets. An illustrative case study of 'Direct Action,'2 a 1980s-era Canadian terrorist group will be presented as an example of a domestic terrorism within a social movement.

\footnotetext{
${ }^{1}$ After Eckstein; Harry Eckstein, Regarding Politics: Essays on Political Theory, Stability, and Change, Berkeley: University Press, 1992: 148-149.

2 The group is better known by its media moniker 'the Squamish Five' or the 'Vancouver Five,' but 'Direct Action' is the name they chose for themselves, and so will be used throughout the paper.
} 


\section{Why Munson's process}

Ziad Munson's theory of activist mobilisation, while not developed to explain radicalisation into terroristic violence, was elected for testing in this study because it offers a tantalizing promise: a simple, easily-observable step-wise transition from non-activist to activist, and a corresponding explanation as to how and why activists embrace the ideas and tactics that they do. Assuming terroristic violence-bombing, arson, assassination, and the like - to be a rationally-chosen tactical tool in some activists' toolboxes, Munson's theory should offer insight into why only some activists adopt such tactics. As will be discussed below, Munson's theory shares similarities with already-extant theories of violent radicalisation and activist mobilisation, but offers advantages over these.

A hybrid most-likely test/ plausibility probe of Munson's process of social activist mobilisation will be initially conducted using 'Direct Action' (DA) as violent case subjects, with a selection of non-violent activists involved with the same issues as a non-violent comparison group. Case histories of non-DA affiliated persons who have used terroristic violence to further variety of causes, including far-right and -left politics, ethno-nationalism and Islamism, will then be assessed to determine whether Munson's theory can be applied beyond environmentally-related terroristic violence. The results of this analysis will be presented, along with suggestions for further research. 


\section{Research context}

We know a considerable amount about meso- and macro-level mobilisation into political violence and terrorism: the group-level or societal effects which can work upon an individual and contribute to their choosing to join a terrorist group: the political milieus which give rise to terrorism; 3 the group psychology which binds members to each other; 4 the influence of ideology or religion on the acceptance of violence, and; the rough demographic profile of who becomes a terrorist. ${ }^{5}$ So far, while attempts to identify the causes of terrorism have been seemingly very accurate, in that various hypotheses manage to capture large numbers of terrorists in their explanatory net, they have failed to be precise: that is, they have failed to consistently distinguish between those individuals ticking all the boxes in the terrorist checklist who do eventually becomes terrorists, and the exponentially greater number of box-tickers who do not. As well, theoretical models of terrorist mobilisation have focussed almost exclusively on Islamic

\footnotetext{
3 For example Justin Magourik, “Connecting A Thousand Points of Hatred," Studies in Conflict \& Terrorism 31 (2008):327-49; Jocelyn Viterna,"Pushed, Pulled and Persuaded: Explaining Women's Mobilization into the Salvadorean Guerrilla Army," American Journal of Sociology 112:1(2006): 1-45; Jerrold Post, The Mind of the Terrorist, New York: Palgrave Macmillan, 2009.

4 See, for example, Alessandro Orsini, Anatomy of the Red Brigades, Ithaca: Cornell University Press, 2011; Clark McCauley and Sophia Moskalenko, "Mechanisms of Political Radicalization: Pathways Toward Terrorism," Terrorism and Political Violence 20, no. 3 (2008): 415-33; Post "The Mind;"John Horgan, Walking Away From Terrorism, London: Routledge, 2009; John Horgan," The social and psychological characteristics of terrorism and terrorists," in Root causes of terrorism: Myths, reality, and ways forward, ed. Tore Bjoergo, London: Routledge, 2005.

5 For example: Bruce Hoffman, Inside Terrorism, New York: Columbia University Press, 2006; Edwin Bakker, Jihadi terrorists in Europe, The Hague: Cliengendael (2006); Mitchell Silber, Arvin Bhatt, and Senior Intelligence Analysts, Radicalization in the west: The homegrown threat, New York: NY Police Department, 2007.
} 
'radicalisation'6 and often contain steps such as 'religious seeking or conversion' which do not apply to secular violent groups.

Our inability to predict who will or will not turn to terrorism exacts heavy monetary and social costs. Consider the recent focus of governments, counterterrorism (CT) services and law enforcement in Canada , the US and the UK on what is variously termed 'domestic extremism, ${ }^{7}$ 'domestic terrorism, ${ }^{\prime 8}$ or 'singleissue terrorism:'9 violence committed in support of a specific social cause such as environmentalism, animal rights, or abortion rights. Governments differ in the threshold of violence in their definition of single-issue terrorism, from vandalism to murder, but there is consensus that this violence is at the fringe of more legitimate social protest, while tacitly or overtly supported by more mainstream movement members. ${ }^{10}$ Currently, government and practitioner treatments of single-issue terrorism assume that violent political protest is an evolved subset of

\footnotetext{
${ }^{6}$ A non-exhaustive list: Quintan Wiktorowicz, Radical Islam Rising: Muslim Extremism in the West, Maryland: Rowman and Littlefield, 2005; Joshua Sinai, "Radicalization into Extremism and Terrorism," Intelligencer: Journal of US Intelligence Studies 19, no. 2 (2012); Fathali Moghaddam,"The Staircase to Terrorism: A Psychological Exploration," American Psychologist 60, no. 2 (2005); Anja Dalgaard-Nielsen,"Violent Radicalization in Europe: What We Know and What We Do Not Know," Studies in Conflict \& Terrorism 33, no. 9 (2010): 797-814; Hoffman, "Inside Terrorism;" Silber and Bhatt, "Radicalization in the West." For a discussion of the impact of these radicalization narratives on Muslims: Arun Kundnani, "Radicalisation: The journey of a concept," Race \& Class 54, no. 2 (2012): 3-25.

7 Association of Chief Police Officers (United Kingdom) website, http://www.acpo.police.uk/ NationalPolicing/NCDENationalCoordinatorDomesticExtremism/Default.aspx

8 Federal Bureau of Investigation (United States) website http://www.fbi.gov/wanted/dt; Canadian Security and Intelligence Service website https://www.csis-scrs.gc.ca/prrts/trrrsm/ index-eng.asp

9 G. Davidson Smith, "Single Issue Terrorism,” CSIS Commentary No. 74 (Winter 1998) archived at https://www.csis-scrs.gc.ca/pblctns/cmmntr/cm74-eng.asp

${ }^{10}$ Smith's precis provides an excellent example: the opening preamble contains the phrases "legitimate and traditionally moderate organizations," "radical elements," "militant core."
} 
'normal' protest behaviour, in which all social movements have at their fringes violent extremists who share beliefs, if not tactics, with the larger group. ${ }^{11}$

Thus it is also assumed that violent protesters are radicals, radical in their beliefs as well as their actions, and that they reach this violent stage by a process of radicalisation. This is problematic: almost every practitioner definition of 'radicalisation' describes it as a process, a transformation from non-violence to violence, suggesting that the boundaries between activist and violent extremist are fluid and inexact. For instance, in the Danish Security and Intelligence Service (PET) definition, radicalisation is "a process, by which a person to an increasing extent accepts the use of undemocratic or violent means, including terrorism, in an attempt to reach a specific political/ideological objective"(emphasis added.) ${ }^{12}$ This implies that those political or ideological activists who now embrace terroristic violence were once 'normal' activists who did not do so, leaving all activists open to suspicion that they might one day transition into violence. In this belief framework, someone fed up with writing letters to the editor about shale gas exploration might one day start sending gas company executives mail bombs, for instance, as a result of 'radicalisation into

\footnotetext{
${ }^{11}$ For examples of this, see Randy Borum and Chuck Tilby, "Anarchist Direct Actions: A Challenge for Law Enforcement," Studies in Conflict \& Terrorism 28 (2005): 201-23; Joseph Simone Jr, Joshua D. Freilich, and Steven M. Chermak, "Surveying state police agencies about domestic terrorism and far-right extremists," University of Maryland Study of Terrorism and Responses to Terrorism (2008); James Jarboe,"The threat of eco-terrorism," Testimony to the House Resources Committee, Subcommittee on Forests and Forest Health, Washington, DC (2002). For a discussion of the impact of these beliefs, see Steve Vanderheiden, "Eco-Terrorism or Justified Resistance? Radical Environmentalism and the 'War on Terror,"” Politics \& Society 33, no. 3 (2005): 425-447.

12 2009; in Alex Schmidt, "Radicalisation, De-Radicalisation and Counter-Radicalisation," ICCT Research paper, March 2013, available online at www.icct.nl
} 
violence.' The development of radical beliefs, in these models, precedes the adoption of radical tactics.

The monetary costs of this paradigm of radicalisation, for law enforcement and counter-terrorism (CT) practitioners, come as it captures an unmanageable number of potential suspects within its definition: potentially any activist, anywhere, at any time. If one believes terroristic violence to be a potential tool for almost any activist, monitoring for radicalisation is a burdensome process. Even in the post-9/11 era, with its public support for expansions in policing, surveillance and security-and their concomitant budgets-the resources for such an approach do not exist.

For instance, recent revelations in the UK put the number of suspected 'domestic extremists' currently under investigation by a national police unit at almost 9000 $^{13}$. In the lead-in to the Olympic Games in Vancouver, the RCMP spent at least nine months following a university professor who opposed the Games, apparently just one among many targeted for such surveillance. ${ }^{14}$ CSIS threat assessments obtained under Access To Information Act requests show that between 2005 and 2010, Greenpeace-an international environmental group with over 89,000 members in Canada alone- ${ }^{15}$ was the most commonly-cited

\footnotetext{
13 Paul Lewis, Rob Evans and Vikram Dodd, "National police unit monitors 9000 'domestic extremists,", The Guardian (UK) 26 June 2013, at http://www.theguardian.com/uk/2013/jun/ 25/undercover-police-domestic-extremism-unit

${ }^{13}$ CBC News, "Anti-Olympic activist tailed by Mounties, police notes show," 5 September 2013, at http://www.cbc.ca/news/canada/british-columbia/anti-olympic-activist-tailed-by-mountiespolice-notes-show-1.1404683

${ }^{15}$ From Greenpeace Canada website, www.greenpeace.org/canada/en/About-us/FAQ
} 
threat group in the assessment. ${ }^{16}$ How are so many people to be effectively monitored for terroristic activity? The simple answer is they cannot be; law enforcement agencies must instead rely on information to reduce this vast pool of potential terrorists into a more manageable size. So far, the criteria for suspected extremism seem to involve ideology-anarchism, for instance, ${ }^{17}$ or deep ecology; behaviour-direct action tactics and civil disobedience, ${ }^{18}$ and; beliefs- such as opposition to resource extraction or globalization. ${ }^{19}$

However, these rough criteria only reduce the number of suspected terrorist in potentia somewhat, and bring with them a social cost: the vilification-byassociation of environmental activists, even those whose protest tactics fall well within societal or legal norms. The conflation of beliefs and actions that is common to most explanations of violent radicalisation - that people act a certain (violent) way because of their (extreme) beliefs-is not only most likely inaccurate ${ }^{20}$ but also potentially dangerous, given the body of research that exists

\footnotetext{
${ }^{16}$ Jeffrey Monaghan and Kevin Walby, "Making Up 'Terror Identities': Security intelligence, Canada's Integrated Threat Assessment Centre and social movement suppression," Policing and Society 22:2 (2012), 144.

${ }^{17}$ For an excellent example of the attribution of violence to anarchism, see Borum and Tilby, "Anarchist Direct Actions." The authors start their analysis by stating that not all anarchists are terrorists, but then blur the distinction themselves.

${ }^{18}$ Greenpeace's frequent illegal, but peaceful civil disobedience campaigns would be an excellent example.

${ }^{19}$ Anti-globalization is identified as a motivator for a new breed of 'Militant Environmental Activist' in Mark Button et al. "New challenges in public order policing: the professionalization of protest and the emergence of the militant environmental activist," International Journal of the Sociology of Law 30 (2002):17-32.
}

${ }^{20}$ See Jamie Bartlett and Carl Miller, “The Edge of Violence: Towards Telling the Difference Between Violent and Non-Violent Radicalization," Terrorism and Political Violence 24, no. 1 (2012): 1-21, for a discussion of the prevalence of 'extremist' beliefs related to political Islam within the non-violent Muslim population, which strongly suggest the fit between beliefs and actions is imperfect, as well as culturally constructed. 
suggesting that the perceived dismissal or repression of legitimate social protest ${ }^{21}$ produces an escalation into violence in a movement. ${ }^{22}$ Suggesting, for instance, that all those who oppose the further development of the Alberta oil sands have a "radical ideological agenda" or are members of "radical groups," as Canada's Minister of Natural Resources did in $2 \mathbf{O 1 2}^{23}$ sends a signal to non-violent activists and sympathetic non-activists alike that their concerns will not be heard in their present non-violent form.

In order to further reduce the resources required to effectively detect and prevent terroristic protest violence, a means of distinguishing between those activists who will become violent and those who will not would be of benefit. This study investigates whether Munson's theory can provide that means. This paper will proceed with a discussion of extant research into individual-level variables contributing to violent and non-violent mobilisation. Munson's theory of mobilisation will then be discussed in depth, having been situated within the literature, and then the methodology used to test his theory's applicability to terrorism research will be detailed. The results of the plausibility probe are then

\footnotetext{
${ }^{21}$ Many, but see especially Donatella Della Porta, Social Movements, Political Violence, and the State, New York: Cambridge University Press, 1995; Louise Richardson, What Terrorists Want, New York: Random House, 2007; Post, "The Mind of the Terrorist."

${ }^{22}$ This is a very common explanatory narrative among those convicted of environmental and animal-rights related violence. For example, Rebecca Rubin, the Canadian recently imprisoned for ELF and ALF-linked violence in the early 2000s, testified at her sentencing of her frustration that her years of non-violent protest failed to change the actions of either the governments or resource-extraction companies she targeted. Sandra Contento, "The Rise and fall of 'eco-terrorist' Rebecca Rubin,” Toronto Star 2 Feb. 2014, at http://www.thestar.com/news/insight/ 2014/02/02/the_rise_and_fall_of_ecoterrorist_rebecca_rubin.html

${ }^{23}$ Laura Payton, "Radicals working against oilsands, Ottawa says," CBC News 9 Jan. 2012, at http://www.cbc.ca/news/politics/radicals-working-against-oilsands-ottawa-says-1.1148310
} 
presented, and finally a discussion of the results, with recommendations for policy and future research. 


\section{Chapter 2: Literature Review}

\section{Overview}

Because of the attempt in this study to probe the utility of a non-terrorist theory of mobilisation for predicting terroristic behaviour, it is necessary to review the literature from both armed or violent mobilisation as well as nonterroristic social movement mobilisation. In seeking to answer how some individuals are mobilised into terroristic violence, it is useful to examine extant micro-level explanations of political participation, protest behaviour, and violent or armed participation.

If counterintuitive at first glance, it is not without precedent to seek to utilize non-terrorism related research to explain violent mobilisation; terrorism and political violence, like social activism, are complex human phenomena, and, "by its nature, the study of terrorism is multidisciplinary, inviting the insights of psychologists, sociologists, anthropologists, political scientists, historians, economists, engineers, and computer scientists." ${ }^{24}$ If we consider terroristic political violence to be on the spectrum of political behaviour, then we might expect the predictors of less-violent, non-terroristic protest behaviour to correlate with more aggressive participation as well. Moreover, in contrast to many investigations of terrorist radicalisation, studies focussing on conventional political behaviour more often use empirical methods and control groups to better differentiate between mobilised and non-mobilised individuals, making their conclusions more robust.

\footnotetext{
${ }^{24}$ Marc Sageman, "The Stagnation in Terrorism Research,” Terrorism and Political Violence,
} 26:4 (2014): 569 . 
In individual-level analyses of both non-violent and terroristic movement mobilisation, there are several commonalities found, most strikingly: the recruitment via personal contacts in existing social networks-friends, kin, colleagues in other movements; the necessity of biographical availability, i.e. the ability to take part if invited to join, and; a precipitating life event or cognitive opening, through which an individual is more receptive to information or ideology. Finally, there are psychology-based explanations for protest participation and mobilisation into violence, which point to an individual's personality and psychological state as the foundation of their likelihood of mobilisation.

\section{Network contacts and 'asking'}

The political participation, social movement and terrorism literature all point to the importance of networks of friends, family and colleagues as being integral to recruitment and mobilisation. Social ties to already-mobilised individuals facilitate contact with a group or movement, as well as provide a 'fun' reason for a not-already mobilised individual to take part in movement activities, even in the absence of a pre-existing interest in the issue at hand. Movement contacts also encourage individuals mobilised around one issue to become engaged with another. Even when an author is not specifically proffering a testable theory of mobilisation, the importance of such 'ties' is apparent. 
Networked social ties are correlated with an array of non-violent social mobilisation, political participation and, in particular, protest participation ${ }^{25}$. For example, one study of anti-nuclear protestors in California saw 51\% of protestors identify 'family and friends' and 'previous activism' as being 'very important' factors in their recruitment. ${ }^{26}$

The importance of the strength of the tie is unclear, with some authors finding a stronger tie-in essence, a stronger relationship: loved one vs. neighbour, or friend vs. colleague-a better predictor of joining ${ }^{27}$ and others arguing that the strength of the initial tie between mobilising individual and moment contact is less important than the bond or tie that develops during mobilisation. ${ }^{28}$ For high risk activism in particular, ${ }^{29}$ both strong and weak ties are significant: participants have more ties to political, civic and civil rights

\footnotetext{
25 Annette Linden and Bert Klandermans, "Stigmatization and Repression of the Extreme Right in the Netherlands," Mobilization 11 (2006) pp. 141-157; James Jasper and Jane Paulsen, "Recruiting Strangers and Friends: Moral Shocks and Social Networks in Animal Rights and AntiNuclear Protests," Social Problems 42:4 (1995) pp. 493-512; Florence Passi and Marco Giugni, "Social Networks and Individual Participation: Explaining Differential Participation in Social Movements," Sociological Forum 16:1 (2001) pp. 123-53; Karl-Dieter Opp, Kate Burow-Auffarth, and Uwe Heinrichs, "Conditions for Conventional and Unconventional Political Participation: An Empirical Test of Economic and Sociological Hypotheses," European Journal of Political Research 9 (1981) pp.147-68; Sharon Nepstad and Christian Smith, "Rethinking Recruitment into High Risk/Cost Activism: The Case of Nicaragua Exchange," Mobilization: An International Quarterly 4:1 (1999) pp. 25-40; Rory McVeigh and Christian Smith,"Who Protests in America," Sociological Forum 14:4 (1999) pp.685-702.

${ }^{26}$ Jasper and Paulsen, "Recruiting Strangers.”

27 Nicolas Somma,“How Do Voluntary Organizations Foster Protest?” Sociological Quarterly 51 (2010) pp. 384-407; Nicolas Somma,"How Strong Are Strong Ties? The Conditional Effectiveness of Strong Ties in Protest Recruitment Attempts," Sociological Perspectives 52:3 (2009) pp. 289-308; Doug McAdam, Recruitment to High-Cost Activism: The Case of 'Freedom Summer,", American Journal of Sociology 92:1 (1986) pp. 64-90; Passi and Giugni; McVeigh and Smith.

${ }^{28}$ Lorne Dawson, "The Study of New Religious Groups and the process of Radicalization in Terrorist Groups" (DRDC CSS CR 2009-02) Ottawa: Defence Research and Development Canada Centre for Security Science, 2009.

${ }^{29}$ McAdam, "Freedom Summer."
} 
organizations overall, as well as close personal ties to other participants. A similar study of volunteers to Nicaraguan harvest and solidarity brigadesextremely costly and risky activity - found that organizational, or weak, ties were not predictive of participation, but that the presence of relational ties, i.e. ties of friendship, kinship or career, was the single variable that consistently maintained a highly significant influence. ${ }^{30}$

Being directly invited to participate - so-called 'asking' - by a networked contact is a very strong predictor of participation, even among those alreadymobilised or who have many network ties..$^{31}$ Two social groups-Hare Krishnas and animal rights campaigners-have been found to be outliers in terms of interpersonal recruitment and asking, with these groups reporting successful recruitment through stranger approaches (Hare Krishnas) and passive contact with brochures (animal rights groups.) ${ }^{32}$ McCauley and Moskalenko33 identified strong ties and asking as being key to the transition from non-violent activist to violent radical. Preexisting ties have been posited as important to violent

\footnotetext{
$3^{30}$ Sharon Nepstad and Christian Smith, "Rethinking Recruitment to High-Cost Activism: the Case of Nicaragua exchange," Mobilization: An International Journal 4:1 (1999) p. 33

${ }^{31}$ Bert Klandermans, The Social Psychology of Protest, London: Wiley Blackwell, 1997; David Snow, Louise Zurcher, and Sheldon Ekland-Olson, "Social Networks and Social Movements: A Microstructural Approach to Differential Recruitment," American Sociological Review 45, no. 5 (1980): 787-801; Daniel Myers,"The Diffusion of Collective Violence: Infectiousness, Susceptibility, and Mass Media Networks," American Journal of Sociology 106, no.1 (2000): 178-208; Alan Schussman and Sarah Soule, "Process and Protest: Accounting for Individual Protest Participation," Social Forces 84, no.2(2005): 1083-1108; Chaeyoon Lim, "Mobilizing on the Margin: How Does Interpersonal Recruitment Affect Citizen Participation in Politics?" Social Science Research 39, no. 2(2010): 341-55.

${ }^{32}$ Snow et. al., "Social Networks;" Jasper and Poulsen, "Recruiting Strangers."

33 Clark McCauley and Sophia Moskalenko, "Mechanisms of Political Radicalization: Pathways Toward Terrorism," Terrorism and Political Violence 20, no.3 (2008): 415-33.
} 
mobilisation $^{34}$ for individuals as diverse as suicide bombers, ${ }^{35}$ Islamist militants, ${ }^{36}$ Irish republicans, ${ }^{37}$ left-wing European terrorists, ${ }^{38}$ Latin American guerrillas, ${ }^{39}$ and lone-wolf actors. $4^{40}$ Blazak's study of right-wing extremist groups found that recruiters explicitly sought and used pre-existing friendship and kin ties to find potential new members, ${ }^{41}$ emphasizing the power of interpersonal invitations. In an examination of recruits and non-recruits to guerrilla groups, one important difference was that non-recruits reported less previous political

34 John Horgan, "From Profiles to Pathways and Roots to Routes: Perspectives from Psychology on Radicalization into Terrorism," Annals of the American Academy of Political and Social Science 618 (2008): 80-94; John Horgan, Walking Away From Terrorism, London: Routledge, 2009.

35 Paul Gill, "Suicide Bomber Pathways Among Islamic Militants," Policing 2:4 (2008) pp. 412-422.

${ }^{36}$ Dawson (2009); Justin Magourik, "Connecting A Thousand Points of Hatred," Studies in Conflict \& Terrorism 31 (2008): 327-49; Peter Neumann and Brooke Rogers, Recruitment and Mobilisation for the Islamic Militant Movement in Europe, Report for the European Commission (Directorate General Justice, Freedom and Security), 2007; Marc Sageman, Understanding Terror Networks. Pennsylvania: University of Pennsylvania Press, 2004.; Peter Nesser, Jihad in Europe: A survey of the motivations for Sunni Islamist terrorism in post-millennium Europe (FFI/RAPPORT-2004/01146). Norwegian Defence Research Establishment (2004); Wiktorowicz, "Radical Islam Rising".

37 Lorenzo Bosi and Donatella della Porta, "Micro-Mobilization into Armed Groups: Ideological, Instrumental and Solidaristic Paths," Qualitative Sociology 35 (2012): 361-83; Louise Richardson, What Terrorists Want; New York: Random House, 2006; Robert White,"From Peaceful Protest to Guerrilla War: Micromobilization of the Provisional Irish Republican Army," American Journal of Sociology 94, no. 6(1989): 1277-1302.

${ }^{38}$ Bosi and della Porta 2012; Donatella Della Porta, Social Movements, Political Violence, and the State, New York: Cambridge University Press, 1995; Alessandro Orsini, "Poverty, Ideology and Terrorism: The STAM Bond," Studies in Conflict \& Terrorism 35, no.3 (2012): 665-92; Klaus Wasmund, "The Political Socialization of West German Terrorists," in Peter Merkl, ed., Political Violence and Terrorism: Motifs and Motivations, San Francisco: University of California Press, 1986: 191-228.

39 Mauricio Florez-Morris,"Why Some Colombian Guerrilla Members Stayed Until Demobilization: A Micro-Sociological Case Study of Factors That Influenced Members' Commitment," Terrorism and Political Violence 22, no. 2(2010): 216-41; Jocelyn Viterna, "Pushed, Pulled and Persuaded: Explaining Women's Mobilization into the Salvadorean Guerilla Army," American Journal of Sociology 112, no. 1 (2006).

${ }^{40}$ McCauley and Mosalenko, "Political Radicalization."

${ }^{41}$ Randy Blazak, “White Boys to Terrorist Men,” American Behavioral Scientist 44:6 (2001) p. 992. 
involvement ${ }^{42}$ and therefore fewer network ties. A consideration of the clandestine nature of most terrorist groups makes the necessity of a personal contact with an already-mobilised person obvious; even if one were to seek out a violent group to join, the groups would still likely want to check out one's bona fides, as "no terrorist wants to try to recruit someone who might betray [them]." 43 Without this personal contact, the road to joining a terrorist group can be difficult: Dermot Finucane, whose late older brother had been an IRA member, recalled that when he decided at age 17 to try and join the IRA, it was difficult to do so, as "he didn't know whom to talk to or how to join."44

\section{Biographical availability}

Of course, contact alone cannot fully explain mobilisation, or its nonoccurrence. While a personal contact with group or movement seems necessary to mobilisation, another key factor in differential political participation, and in particular protest participation, seems to be the ability of individuals to commit the time and resources necessary to activism when invited to do so. This interplay of employment, age and family status is often referred to as 'biographical availability,' and can be thought of as a function of a cost-benefit analysis of political participation. Increased biographical availability reduces the

\footnotetext{
${ }^{42}$ Viterna, "Pushed Pulled," 35.

43 McCauley and Mosakalenko, "Political Radicalization," 420.

${ }^{44}$ Richardson, "What Terrorists Want," 73. Another of Finucane's older brothers, Pat, was a solicitor who was murdered in an alleged collusion between Loyalist paramilitaries and the British security services; another brother was interned for a year. In the words of yet another brother, "you just got involved [with the IRA] because you were caught up in it." There is unfortunately very little written about people in similar situations who do not join paramilitary organizations.
} 
cost of participation in activism and terrorism, as 'available' individuals have less to forgo in terms of time, money or personal commitments; this participation therefore 'costs' them less. The popular trope of engaged, rabble-rousing university students is perhaps based in reality: students have greater biographical availability than older or working adults, who are more constrained by the demands of a job or family life.

Biographical availability has been confirmed as significant in many studies of non-violent social group or protest mobilisation. ${ }^{45}$ It is particularly relevant to 'high-cost' activism, that which involves greater personal risk or illegal activity ${ }^{46}$ although Cameron and Nickerson ${ }^{47}$ found age to be insignificant in predicting the likelihood of violent protest activity, instead finding gender-specifically, being male-to be more relevant. Different kinds of political participation can affect availability for other forms,as well: Somma ${ }^{48}$ found that heavy investment in non-protest activism makes one less available for protest participation: group members with a medium level of resource commitment to the movement were the most likely to protest, not the most heavily involved. Unexpectedly, youth and

\footnotetext{
45 Somma, "Voluntary Organizations;" Somma, "Strong Ties;” Michelle Petrie, "A Research Note on the Determinants of Protest Participation: Examining Socialization and Biographical Availability," Sociological Spectrum 24:5 ( 2004): 553-74; Nepstad and Smith, "Rethinking Recruitment;" McAdam "Freedom Summer;" Steven Finkel, Edward N. Muller, and Karl-Dieter Opp, "Personal influence, collective rationality, and mass political action," The American Political Science Review (1989): 885-903; Opp et al. "Political participation;" Snow, et al."Social Networks."

${ }^{46}$ McAdam "Freedom Summer."; Robert White "Micromobilization;" Bert Klandermans and Dirk Oegema, "Potentials, networks, motivations, and barriers: Steps towards participation in social movements," American Sociological Review (1987): 519-531; Klandermans, "Psych. of Protest;" Muller, "Explanatory Model;" Opp et al. "Political Participation;" Peter Eisinger,"The conditions of protest behavior in American cities," The American Political Science Review (1973): 11-28.

47 James Cameron and Shannon Nickerson, "Predictors of Protest Among Anti-Globalization Demonstrators," Journal of Applied Social Psychology 39, no.3 (2009): 734-761.

${ }^{48}$ Somma, "Strong Ties."
} 
biographical availability were not found to be predictive of participation in extremely risky activism in Nicaragua. 49

Even more so than licit political participation, terrorist activity is costly in terms of time, resources and opportunity-lost wages, education, relationshipsand requires that an individual be either free of constraining commitments or willing to forgo these to participate. Thus, availability has been shown to be a strong influence on mobilisation into terrorism ${ }^{50}$ and guerrilla groups ${ }^{51}$ as well as an indirect correlate with age in terrorism more generally..$^{5^{2}}$ The importance of family ties as a barrier to violent participation has been noted by both researchers ${ }^{53}$ and by terrorist groups themselves: an (alleged) al Qaeda recruiting handbook suggests that potential recruits not be forcibly separated from their families, but rather groomed with "a radical mindset over time until he takes the initiative to separate from his family and prepares to engage in violence," 54 the

\footnotetext{
49 Nepstad and Smith, "Rethinking Recruitment."

$5^{0}$ Claude Berrebi,"Evidence about the link between education, poverty and terrorism among Palestinians," Peace Economics, Peace Science and Public Policy 13, no.1 (2007); White, "Micromobilization.".

${ }^{51}$ Lewis Taylor, Shining Path: guerrilla war in Peru's northern highlands, 1980-1997, Liverpool: Liverpool University Press, 2006; Viterna, "Pushed Pulled."

$5^{2}$ Marc Sageman, Leaderless Jihad: Terror Networks in the Twenty-First Century, Philadelphia: University of Pennsylvania Press, 2008; Sageman, "Terror Networks;" Simon Cottee and Keith Hayward, "Terrorist (E)motives: The Existential Attractions of Terrorism," Studies in Conflict \& Terrorism 34 (2011)963-986; Bakker,"Jihadi terrorists;" Tomas Precht, Home grown terrorism and Islamist radicalisation in Europe: From conversion to terrorism: An assessment of the factors influencing violent Islamist extremism and suggestions for counter radicalisation measures. Copenhagen: Danish Ministry of Justice, 2007; see Noemie Bouhana and Per-Olof Wikstrom, Al Qa'ida-Influenced Radicalisation: A Rapid Evidence Assessment Guided by Situational Action Theory, London: 2011, for a discussion of age, terrorism and violence.
}

53 Kurzman, Wilson, and Taylor, in Kim Cragin, "Resisting Violent Extremism: A Conceptual Model for Non-Radicalization," Terrorism and Political Violence 26:2 (2014).

${ }^{54}$ Abu 'Amral-Qa'idi, A Handbook in the Art of Recruitment, New York: West Point Counter Terrorism Centre (2002), in Cragin, 576 
implication being that a family man, preoccupied with his wife and children, would be of no use to the organization.

The interaction between 'availability' markers (socio-economic status, employment, educational achievement, etc.) and terrorism is complex: although better-educated people are theoretically more employable and therefore could be expected to have more to 'lose' by participating in terrorism, empirical studies have not borne this out entirely. Berrebi found that while being married decreased the likelihood of participation in suicide terrorism, higher levels of education in fact increased that likelihood. ${ }^{55}$ Orsini's analysis of Red Brigades (BR) members confirmed this last finding-that terrorism was the domain of the more educated - with university graduates and the middle class represented disproportionately in the BR ranks. ${ }^{56}$ However, White's comparative analysis of Irish Republican Army and Social Democratic Labour Party (SDLP) ${ }^{57}$ supporters suggests that the high cost of violent participation dissuaded the middle-class and educated from joining the IRA, funnelling them towards the conventional politics of the SDLP instead. $5^{8}$ Bartlett and Miller found "marginally higher levels of education" among non-violent radicals than terrorists, ${ }^{59}$ while in a group-level

\footnotetext{
55 Berrebi, "Education and Poverty,"674.

${ }^{56}$ Orsini, “Red Brigades,” 66.

57 A Nationalist party that advocates for a united Ireland but formally eschews violence.

${ }^{8}$ White, "Micromobilization." It is very likely that there is more at play in this instance than mere biographical availability, including differences in cultural attitudes towards violence as well as belief in the effectiveness of conventional political participation.

59 Jamie Bartlett and Carl Miller, "The Edge of Violence: Towards Telling the Difference Between Violent and Non-violent Radicalization," Terrorism and Political Violence 24, no.1 (2012): 7.
} 
analysis, ${ }^{60}$ lower relative educational status was correlated with an increased likelihood of violence.

\section{Life event or cognitive opening}

Munson's theory posits that a change in employment, family status or location precedes mobilisation, because these 'turning points,' are "personal changes that create biographical and cognitive availability,"61 allowing an unmobilised individual to come into contact with people and ideas that they had hitherto not been exposed to. Both physical and cognitive change points have previously been identified as important to violent and non-violent mobilisation ${ }^{62}$ as well as religious conversion. ${ }^{63}$ A similar pattern has been suggested for terrorist mobilisation, although many authors within the terrorism literature have tended to frame these openings as responses to trauma, grievance or psychological distress ${ }^{64}$ especially in the context of al-Qaeda inspired or Islamic

\footnotetext{
${ }^{60}$ Renat Shaykhutidinov, "Education for peace: protest strategies of ethnic resistance movements," Journal of Peace Education 8, no.2 (2011): 143-155.

${ }^{61}$ Munson, 48

${ }^{62}$ Linden and Klandermans, "Stigmatization."

63 Dawson, DRDC; David Snow, and Richard Machalek, "The sociology of conversion," Annual review of sociology (1984): 167-190; John Lofland and Rodney Stark,"Becoming a World-Saver: A Theory of Conversion to a Deviant Perspective," American Sociological Review 30,no.6 (1965): $863-75$.

${ }^{64}$ Bosi and Della Porta, "Armed Groups;” Robert Barrett,"Interviews with Killers: Six Types of Combatants and Their Motivations For Joining Deadly Groups," Studies in Conflict \& Terrorism 34, no.10 (2011): 749-64; Alex Wilner,and Claire-Jehanne Dubouloz, "Homegrown Terrorism and Transformative Learning: An Interdisciplinary Approach to Understanding Radicalization," Global Change, Peace \& Security 22, no.1 (2010):33-51; Dawson, "DRDC;" John Olsen, Roads To Militant Radicalization: DIIS Report 2009:12, Copenhagen, 2009; Gill, "Suicide Bombers;" Neumann and Rogers, "Recruitment;" Silber and Bhatt, "Radicalization in the west;" John Horgan,"The social and psychological characteristics of terrorism and terrorists," in Tore Bjoergo, ed. Root causes of terrorism: Myths, reality, and ways forward, London: Routledge (2005): 44-53; Farhad Khosrokhavar, Les nouveaux martyrs d'Allah, Paris: Flammarion, 2003; Wiktorowicz, "Radical Islam;" Sageman, "Understanding Terror."
} 
terrorism, wherein conversion or a reaffirmation of faith are typically seen as "a method of overcoming personal problems.”65 For example, Viterna's analysis identified joiners of guerrilla groups as being more likely to have experienced 'crises'-either personal or situational, such as state repression, eviction, family break up-than non-joiners. ${ }^{66}$

In studies of terrorist mobilisation, physical relocation and cognitive opening are often conflated, as in Sageman ${ }^{67}$ and Vidino. ${ }^{68}$ Some authors ${ }^{69}$ believe that cognitive opening or psychological susceptibility can be brought on by indirect experiences or group-level grievances or repression, not just personal experiences. Wikotorowicz also identifies discussion with the already-mobilised as a potential source of cognitive opening, while Gill's four stages of mobilisation into suicide bombing $7^{70}$ place the exposure to radical 'propaganda' as preceding such 'catalysts.' With the exception of Viterna, most of the research into violent mobilisation is weakened by choosing to study only those already mobilised, or falls into a post hoc analysis whereby a crisis is assumed to invoke a religious transformation, which in turn prompts the turn to violence. Research comparing non-violent religious converts, or persons for whom a crisis provokes no religious feelings whatsoever, would be useful.

\footnotetext{
65. Gill , "Suicide Bombers," 416.

66. Viterna, "Pushed Pulled,” 35.

${ }^{67}$ Sageman, "Understanding Terror."

68 Vidino, "Pentiti."

${ }^{69}$ Gill, "Suicide Bombers;” Neumann and Rogers, "Recuitment;" Khosrokovar, "Martyrs;" Wiktorowicz, "Radical Islam;" Silber and Bhatt, "Radicalization in West;" Olsen, "Roads to Militant."

70 Gill, “Suicide Bombers.”
} 


\section{Psychology and Emotions}

Although most authors agree that, with the possible exception of so-called 'lone wolves', terrorists are psychologically normal ${ }^{71}$ there have been many studies seeking to show the impact of an individual's psychological or emotional state on their mobilisation, especially into violence. ${ }^{72}$ The desire for revengeone of Richardson's three Rs, the others being Renown and Reaction-73 is cited by researcher and terrorist alike as a powerful motivation for joining violent groups. ${ }^{74}$ Revenge can be sought for an individual or micro-level wrongs, such as a brother killed by security forces, or a home destroyed;75 for meso-level harms such as state repression of a neighbourhood or ethnic group; ${ }^{76}$ and for macrolevel perceptions such as the "war on Muslims." This 'defensive' explanation for violence as being in reaction to another's provocation is commonly given by terrorists (or 'freedom fighters') themselves. ${ }^{77}$ Interestingly, Moskalenko

\footnotetext{
${ }^{71}$ Martha Crewnshaw, Explaining Terrorism, London: Routledge, 2011; McCauley and Moskalenko; Post, "Mind of the Terrorist;" Richardson, "What Terrorists."

${ }^{72}$ For instance, Michael King and Donald Taylor, "The Radicalization of Homegrown Jihadists: A Review of Theoretical Models and Social Psychological Evidence," Terrorism and Political Violence 23, no. 4 (2011): 602-22 and Cottee and Hayward, "Terrorist Emotives" have speculated that violent protest and terrorism appeal to 'sensation-seeking' individuals who seek out very strong stimuli such as crime and violence to fulfill an inborn psychological need.

73 Richardson, "What Terrorists Want," 72.

${ }^{74}$ A partial list: Baumann "How it All;" Giorgio, "My life;" Richardson, "What Terrorists;" Post, "The Mind;” Horgan, "Walking Away;” Orsini , "STAM;"Crenshaw, "Explaining.”.

75 McCauley and Moskalenko, "Political Radicalization;” Gill, "Suicide Bombers;" Karen Jacques and Paul J. Taylor. "Male and Female Suicide Bombers: Different Sexes, Different Reasons?" Studies in Conflict \& Terrorism 31, no.4 (2008): 304-326; Sageman "Understanding Network;" Sageman, "Leaderless Jihad."

${ }^{76}$ For example: Donna Della Porta, and Heinz-Gerhardt Haupt, "Patterns of Radicalization in Political Activism: An Introduction," Social Science History 36, no.3 (2012): 311-320; Fathali Moghaddam, "The Staircase to Terrorism: A Psychological Exploration," American Psychologist 60, no.2(2005); Post et al., "In Own Words."

77 Taylor and Quayle, in Horgan, "Profiles to Pathways," 86.
} 
identifies this kind of reactive grievance-led mobilisation in US Army recruits following the attacks of $9 / 11 .{ }^{78}$ It is important to note that the grievance need not be actual; "what matters is that [potential terrorists] accept that these grievances exist and thinking terms of victimhood," 79 and that violence is a legitimate response.

\section{Conclusion}

All of these explanations of mobilisation-and the many more focussing on group- and societal-level variables-tell us more about how people come to political participation, be it violent or non-violent. Contact, biographical availability, cognitive openings and psychology can give one a general picture of individual mobilisation, but separately, they do not explain the wide gulf between the number of people exposed to these variables, and the few who mobilisemuch less the many-times-fewer still who mobilise into violence. For example, almost everyone experiences hardship or change in their lives; cognitive or psychological distress is common, and almost impossible to detect 'before the bang.' Many people are exposed to protest movements through school, or in the streets, yet never mobilise. How to explain the friends and family members of activists and terrorists who never themselves engage? The following discussion of Munson's theory, which synthesizes elements of many of the above-discussed

\footnotetext{
${ }^{78}$ Sophia Moskalenko, "Civilians into warriors: Mechanisms of mobilization in US Army recruitment and training," Dynamics of Asymmetric Conflict 3, no.3 (2010): 248-268.

79 Alex Wilner and Claire-Jehane Doubouloz, "Homegrown terrorism and transformative learning: an interdisciplinary approach to understanding radicalization," Global Peace, Change and Security 22,no. 1 (2010): 43
} 
research into a more congruent (and testable) whole, aims to answer more wholly the question of differential mobilisation, both violent and non-violent. 


\section{Chapter 3: Munson's theoretical framework}

\section{Introduction}

"We may identify a whole set of characteristics we attribute to [activists] but not all activists will ever share all of those characteristics.

Moreover, many nonactivists will have these same attributes. The causal connection between individual attributes and activism will therefore always be weak, no matter how many individual characteristics we identify or how many people we include."80

Ziad Munson, an American sociologist, set out in his book "The Making of Pro-Life Activists: How social movement mobilisation works," ${ }^{81}$ to explain the difference between those individuals who became anti-abortion activists and those who, while having similar beliefs, did not. Previous research into antiabortion activism had focused on the difference between pro- and anti-abortion protesters: their demographics, education, geographical profiles, etc-while neglecting the question of why, when a majority of Americans profess some degree of 'pro-life' beliefs, are there relatively few actively engaged movement activists? ${ }^{82}$ He sought to more fully explain the process of becoming mobilised into anti-abortion activism by looking at the process itself, and not the participants' individual characteristics. Munson undertook three years of intensive research in four major cities in the United States, each with a strong pro-life movement, but varying in demography-in particular in religious denomination and religiosity. Using semi-structured life history interviews, he

\footnotetext{
${ }^{80}$ Ziad W. Munson, The Making of Pro-life Activists, Chicago: University of Chicago Press, 2008, 4.

${ }^{81}$ The book is based on his Harvard doctoral research and dissertation.

${ }^{82}$ Munson, 3 .
} 
interviewed over one hundred and fifty people, both non-activists and activists with more than thirty pro-life organizations. ${ }^{83}$

As well as better explaining the process of activist mobilisation, Munson's research also makes an argument for the de-linking of beliefs and action. Previously, activist mobilisation has been seen as an outcome of an individual's beliefs: one comes to feel strongly enough about an issue to take action. In the subset of social movement theory known as 'frame analysis,' for instance, the successful mobilisation of an individual is dependent upon the movement's ability to 'frame' the issue in a manner which resonates with that person's already extant worldview. ${ }^{84}$ New social movement theory, in Munson's précis, sees beliefs as the why of social movements; “a social movement's core task is to reflect and affirm the identities and beliefs of its members." ${ }_{55}$ Similarly, political science explanations of social movement participation have tended to focus on movements as rational venues for the expression of social and political beliefs. In all these explanations, beliefs precede movement participation, ${ }^{86}$ but Munson found that there was little empirical evidence to support a difference in beliefs held between non-activists and activists before their mobilisation.

\footnotetext{
83 Munson, 13.

${ }^{84}$ Snow et al. "Social Networks;" David Snow and Robert D. Benford, "Master frames and cycles of protest," Morris and McClurg, eds. Frontiers in social movement theory, Philadelphia: Yale University Press, 1992; Robert D. Benford and David A. Snow, "Framing processes and social movements: An overview and assessment," Annual review of sociology (2000): 611-639, in Munson, 5 .

85 Munson, 5 .

${ }^{86}$ See for instance, Edward Muller,and Karl-Dieter Opp, "Rational choice and rebellious collective action," The American Political Science Review (1986): 471-488.
} 
Munson affirmed instead that it is in fact activism that precedes the formation of concrete pro-life beliefs. Munson's activists saw “their views change during the actual process of becoming activists-that is in the process of becoming mobilised." 87 Many of the anti-abortion activists Munson interviewed had, prior to their mobilisation, held no opinion about abortion; some described themselves as pro-choice, even. ${ }^{88}$ The difference between activists and nonactivists was not in the depth or strength of their convictions about abortion, but in the level of congruency of their various 'pro-life' beliefs: activists were uniform in feeling that all abortion at any time was wrong, while non-activists were more likely to consider exceptions in the case of rape or incest, for example. ${ }^{89}$

Moreover, activists' beliefs were rarely homogenous, and reflected the various forms of activism, or 'streams' within the larger pro-life movement. For instance, someone who participated in prayer vigils outside abortion clinics might have different ideas as to why abortion is wrong than someone whose primary form of activism was volunteering at crisis pregnancy centres: "the kinds of beliefs activists hold ... are a function of the stream in which they become active," and contained within these streams are beliefs concerning which forms of activism are the most useful. ${ }^{\circ}$ Interestingly, Munson also found that activists very rarely crossed streams; that is, once mobilised, they held to one form of

\footnotetext{
${ }^{87}$ Munson, 6.

88 Ibid., 72.

${ }^{89}$ Ibid., 34.

${ }^{90}$ Ibid., 7.
} 
action, and when they were no longer able to participate in that way, they often left anti-abortion activism altogether, instead of shifting streams.

\section{Munson's Mobilisation Process}

Based on his extensive interviews with activists and non-activists, Munson developed a theoretical pathway of mobilisation. Each step is contingent upon the one that precedes it, and can be considered causally linked. Most importantly, "the steps highlight the high degree of contingency in the process, a contingency that helps explain why very few people actually become activists despite pro-life identity's becoming commonplace." ${ }^{91}$ The steps are:

1. Contact with the movement at a turning point in one's life;

2. Initial Activism;

3. Development of pro-life beliefs, and;

4. Full movement participation.

\section{1a. Movement Contact}

For Munson, the initial contact with a social movement must be firstly personal-as in a direct contact with a person already involved in the movement, not just a passive reading of materials, for example-and secondly, it must be specific to the social movement at hand. Munson's research supports previous findings of the importance of social networks in social movement recruitment. Many of his activist subjects had been introduced to pro-life activism through colleagues, friends, congregation members, family members or neighbours. Overall, eighty percent of his subjects identified a network-based contact with the

\footnotetext{
${ }^{91}$ Munson, 48. It is this contingency which prompted me to consider testing the applicability of Munson's theory to mobilisation into political violence and terrorism.
} 
anti-abortion movement as their entrance into activism..${ }^{92}$ These moments of contact, while coming about through pre-existing social ties, were on the whole found by Munson to be haphazard, not the result of planned recruitment by movement organizers. Nor were the contacts necessarily the result of shared beliefs about abortion drawing people together; instead, they were the product of unrelated social activity ${ }^{93}$ such as church, bowling, other volunteering or book clubs.

\section{1b. Turning Points}

As important as movement contacts are to activist mobilisation, Munson found that when these contacts occur is even more predictive of mobilisation: "personalized contact with the movement is the critical first step in the mobilisation process, but only when it occurs in the context of a turning point in an individual's life. Turning points are those periods when people are required to make significant changes in their everyday life and, as a result, must also reorient their way of looking at and understanding the world."94 Life changes such as moving to a different city, beginning or ending a marriage, the birth of a first child, retirement, or serious illness are examples of such turning points. Religious conversion represents a cognitive, non-physical turning point.

These life milestones produce both physical and mental changes that enable activist mobilisation. Physically, a shift in routine enables a person to have

\footnotetext{
92. Munson, 50.

93. Ibid. 54 .

94 Ibid. 55 (emphasis added.)
} 
contact with a different sphere of people: new college roommates, members of a book club or mothers' group, acquaintances at a newly-frequented dog park. Moreover, these shifts can produce a cognitive-emotional state in which 'turning' individuals are actively seeking new social bonds to replace those left behind in their old lifestyles. These new connections facilitate movement contacts. Through a changed routine and worldview, and the introspection that can accompany such change, these spontaneous or haphazard movement contacts have more of an impact on a 'turning' individual than they might otherwise have had. Some of these turning points also bring about what is termed 'biographical availability;' that is, 'the absence of personal constraints that may increase the costs and risks of movement participation such as full-time employment, marriage and family responsibilities," 95 making an individual simply more able to become mobilised than before the turning point.

\section{Initial Activism}

The second step, initial activism, "represents the first time a person actually participates in [a] movement activity." 96 The movement contact provides the template for the mobilising individual's subsequent activism: if the contact was involved in seeking an electoral solution to an issue-by writing politicians, or picketing a legislative body, for instance-the mobilising person experiences this kind of activity as as their first sample of activism. Munson found that neither a person's beliefs about an issue, nor about the efficacy of various pressure tactics,

\footnotetext{
95 McAdam, "Freedom Summer,"60, in Munson, 56.

${ }_{96}$ Munson, 62.
} 
were determinants of this initial activism; “instead, a person's first activism is determined by the organization through which he or she has come into contact"97-in essence, it is by chance. Indeed, Munson's findings with regards to anti-abortion activists is that most initial activism is motivated not by a strong interest in the issue, but instead by either social involvement-the desire to help out a friend, be a part of something, have fun-or out of "some vague idea that he or she is doing good." 98 This initial activism, which founds an enduring participatory framework for an individual's future activism, is the result of social, not political or ideological, aspirations; concrete beliefs about the issue at hand follow.

\section{Development of Beliefs}

After initial contact with a movement brings about an initial foray into activism, a mobilising person begins to develop their political beliefs more fully, with the influence of their fellow activists driving that development. These beliefs are contextual, and their nuances specific to the organization or environment with which the mobilising individual has initial contact. The homogeneity of ideas within any activist group is the result of the long hours members spend with each other, reinforcing shared beliefs: "a large proportion of what [activist] organizations actually do is provide situations in which a [political] message can be delivered to activists themselves." 99

\footnotetext{
${ }^{97}$ Ibid.

${ }^{98}$ Ibid.

99 Munson, 66 (emphasis added.)
} 


\section{Full Movement Participation}

The deepened beliefs that develop from the ongoing contact with fellow activists form the basis of the fourth and final stage of activist mobilisation: "regularized, sustained participation in the movement."100 Participation begets participation; the social appeal of belonging to a movement, combined with the eventual belief that inaction is impossible creates at this stage a sort of whole-life activist identity. Interestingly, it is at this stage of the mobilisation process that Munson feels 'moral shock,' or motivating outrage, anger or disbelief, is important, rather than as an impetus to initial activism: "these emotions reflect the culmination of the mobilisation process."101 This moral shock combines with the closed social feedback loop provided by an activist group to further distance activists both from non-activists and from activists involved in other 'streams' of activism.

\section{Belief development and activist "streams"}

Building on his findings of actions preceding beliefs, Munson discusses the impact of activism in developing a way of thinking about not only an issue, such as nuclear disarmament, but also the appropriate tactic to bring about change, such as picketing or leafleting. To Munson, activism, and the intense discussions and contact with fellow activists that it brings, shape a mobilising individual's beliefs about an issue. After contact with a movement, "initially vague and inchoate, 'thin' beliefs about [an issue] become richer, more coherent, more

\footnotetext{
${ }^{100}$ Munson, 66.

${ }^{101}$ Ibid., 67.
} 
consistent, and more complex through participation in [activist] work." ${ }^{102}$ The ideas, folkways and mores of the 'contact' person or group are adopted by the mobilising individual, shaping their understanding of an issue in specific ways. Different groups in different activism streams will hold different beliefs about an issue and its resolution, and will socialize their members accordingly. This socialization in the course of mobilisation is so intense and comprehensive that "once they are a part of a stream, individuals seldom move to other streams of the movement. The beliefs they have learned in the course of becoming mobilised lock them into their existing streams." 103

Munson found that pro-life activists' beliefs reflected the activist milieu in which they mobilised, "leading to very different understandings of abortion among activists." 104 Indeed, anti-abortion activists he studied agreed on one thing only: the universal elimination of abortion for any reason. Beyond that, however, the activists he interviewed were the products of the diverse ways in which they had first mobilised as activists. 'Glen,' for instance, who initially supported legal access to abortion, began working for anti-abortion political candidates as part of his larger involvement in politics. In his view, the best way to end abortion is through legal and legislative means, and he discounts the activism of those involved in protests outside clinics, for example. ${ }^{105}$ Abortion for him is an intrinsically political issue, and he has never been involved in anti-

\footnotetext{
102 Ibid., 189.

103. Ibid., 190.

104 Ibid., 64 .

105 Ibid., 98.
} 
abortion activism in any other context or stream. This is in contrast to activists who volunteered with expectant mothers at so-called crisis pregnancy centres (CPCs), for whom abortion was primarily a issue caused by overwhelmed or scared women who could, with counselling, be persuaded to see that not terminating their pregnancies was the best option. Aside from agitating for more CPC funding, the political aspect of abortion remained almost irrelevant for these activists: abortion was, and remained, an individual issue. ${ }^{106}$

This is likely the source of the disagreement between activist groups engaged with the same issue as to what is a) the most important aspect of the issue, and b) the most effective tactic to combat it: different groups have evolved with different ways of thinking, making collaboration more difficult. Because of their divergent activism experiences, their members are unlikely to see eye-to-eye on the issue. Their disparate beliefs are the result of their socialization to different activist groups. ${ }^{107}$ In the animal rights and welfare debate, for example, People For the Ethical Treatment of Animals (PETA) and the Humane Society of the United States (HSUS) both occupy high-profile positions on the pro-animalwelfare side, but with distinctly different approaches and stated beliefs. While both groups have multiple projects concerning domestic and wild animal welfare, HSUS focusses its efforts on legislative and legal change, ${ }^{108}$ while PETA encourages awareness of issues with dramatic advertising campaigns. ${ }^{109}$ While

\footnotetext{
${ }^{106}$ Ibid. 77.

${ }^{107}$ Ibid.

${ }^{108} \mathrm{http}: / /$ www.humanesociety.org/work/

${ }^{109}$ http://www.peta.org/action/campaigns/
} 
PETA and HSUS might have the goal of reducing animal suffering in common, as organizations they (and their supporters) espouse very different beliefs and tactics. This divide is echoed in almost every major social movement.

\section{Applicability to Terrorism Research}

Munson's theory presents a tantalizing possibility: a straightforward stepwise progression from 'civilian' to activist, independent of hard-to-measure variables such as 'depth of beliefs' or 'religiosity.'110 Perhaps most importantly, it is easily observable: no need to imagine what is going on in a person of interest's psyche, but rather to monitor what they have been recently physically doing. With information available to almost any CT or law enforcement practitionerjob history, hometown, educational status-one could compare an individual to Munson's framework and determine whether they were at risk of mobilisation into terroristic violence, or not. Munson's framework combines parts from existing theories of terrorist mobilisation, such as turning points or cognitive openings, biographical availability, and group socialization processes into a simpler, more coherent (and empirically testable) whole. It is for these reasons that it was selected for this study.

${ }^{110}$ See further: Clark McCauley, "Does Political Radicalization Depend on Ideology? Review of Ziad Munson, The Making of Pro-Life Activists: How Social Movement Mobilization Works," Dynamics of Asymmetric Conflict 2, no.3 (2010). 


\section{Chapter 4: Methodology}

\section{Introduction}

Why do some socio-political activists use terroristic violence to further their goals, while others with the same aims do not? In efforts to explain this difference, this study will test the plausibility of Munson's theory of activist mobilisation, to see whether it will firstly: explain non-abortion related activist mobilisation, secondly; explain some of the variance between violent and nonviolent activists, and thirdly; contribute to the understanding of terrorist mobilisation more generally. Using a "structured, focussed comparison" 111 of violent and non-violent activists, this study will present a hybrid most-likely theory test and plausibility probe, using multiple cases of the presence or absence of terroristic protest behaviour to test Munson's theory. This is in line with Yin's analysis of case studies' appropriateness in answering "how" or "why" questions, and that "case studies are particularly useful for testing hypotheses deduced from existing theories." 112

For the first part of the study, non-violent activists were interviewed in a semi-structured format, and their biographies analysed for compatibility with Munson's theory of mobilisation. Munson's theory was then compared against a small Canadian terrorist group, Direct Action, to test whether it is useful is describing violent activist mobilisation. Following this, Munson's theory was tested using open-source information addressing three subsets of violent actors:

\footnotetext{
${ }^{111}$ Jack Levy, “Case Studies: Types, Designs and Logics of Inference," Conflict Management and Peace Science 25(2008): 2.

112 Robert Yin, in Janet Buttolph Johnson, Political Science Research Methods, Washington D.C: CQ Press (2005).
} 
people who use violence to further the causes of environmentalism and animal rights; people who use violence for other single issues such as far-right or -left politics, and; people using violence attributable to Islamist ideals.

\section{Definitions used in the study}

Violence: Herein defined as planned, intentional actions that have the capacity to cause serious harm to persons.

Terroristic violence ${ }^{113}$ : Violence, as defined above, which is committed in order to further a social or political goal, and which is intended to cause fear in an audience beyond the violence's physical target.

Intentionality, planning and the serious harm threshold were included in the definition in order to exclude many incidences of protest-related violence which occur spontaneously or in reaction to external variables, for example: throwing stones or Molotov cocktails at riot police; window breaking and looting, or; fighting between protesters. The wider audience criterion is a common to most definitions of terrorism ${ }_{114}$, and as such distinguishes acts from the merely criminal or retaliatory. Examples of acts that would qualify under these

\footnotetext{
${ }_{113}$ "Terroristic violence" is used here (and throughout) to allow the discussion of individuals and groups whose actions meet all the common criteria of terrorism, but are not specifically aimed at causing physical harm to humans. It also encompasses one-off actions by groups who are not primarily terrorist groups per se, as well as actions by individuals independent of groups, or oneoff actions not meeting the common "campaign" criterion of most terrorism definitions.

'Terroristic violence' acknowledges that such acts share the political nature and target/audience distinction of terrorism. An example of terroristic violence would be the fire bombings favoured by the ELF: while spectacular, and harm-causing, they are designed not to cause physical harm to persons. I reject the lumping in of such actions with, say, the 9/11 attacks, and therefore avoid calling it 'terrorism' or their perpetrators 'terrorists.'

${ }^{114}$ For example: "Usually symbolic in nature, the [terrorist] act is designed to have an impact on an audience that differs from the immediate target of the violence." Post, "The Mind," 3.
} 
definitions include arson, bombings, shootings, or hijackings. Note that the legality/illegality of an action is deliberately not addressed in the definition.

\section{Hypotheses to be tested}

H1: Munson's process of activist mobilisation will hold true for non-violent activism unrelated to abortion.

Ho1: Munson's theory of activist mobilisation will be specific to anti-abortion activism, and will not generalize to other forms of activism/issues.

H1 will be considered confirmed if each of the modified five steps of Munson's mobilisation process (as described below) are found to to be present in more than $75 \%$ of the non-violent case subjects' histories.

H2: Munson's mobilisation process will hold true for terroristic mobilisation. ${ }^{115}$ Ho2: Munson's mobilisation process will not hold true for terroristic mobilisation.

H2 will be considered confirmed if the modified five steps of Munson's mobilisation process (as described below) are present in more than $75 \%$ of the violent case subjects' histories.

\section{Case selection}

\section{Violent Case Studies}

To investigate mobilisation into single-issue terrorism, a specific group whose actions fit the above descriptions of terroristic violence was selected, namely "Direct Action," a small group of self-described anarchists who were active on Canada's West Coast in the early 1980s. Violent case studies were drawn from the five avowed members of "Direct Action" (DA) who were tried and

\footnotetext{
${ }^{115}$ That is, for individual mobilisation into the use of terroristic violence in support of a political cause, whether solo or in a group.
} 
convicted of the bomb attacks on the Cheekeye-Dunsmuir power transmission station, the Litton Industries manufacturing plant, and several Red Hot video outlets. These are: Brent Taylor, Ann Hansen, Douglas Stewart, Gerry Hannah and Juliet Belmas. Not all five members participated in every bombing, and they were also convicted of other related charges including conspiracy related to future plans to attack a military base, shoplifting and robbery. However, the trial and conviction of the five DA members, who claimed their attacks with manifestoes released to the media, ensures that the violent case subjects are verifiably representative of activists who use terroristic violence.

Only three members of DA had sufficient biographical information available to fully test Munson's theory, so other people convicted of terroristic violence in support of ecological or animal-rights causes were assembled from cases in Canada, the United States and the United Kingdom. Drawing on existing open source materials, including journalistic interviews and academic research, this expansion brought the total number of violent cases relating to ecological and animal rights activism to nine. These are tabulated in the line marked "ViolentECO" column in the results table ${ }^{116}$.

In an effort to test the flexibility and potentially wider applicability of Munson's theory of mobilisation, case histories of persons radicalised into other forms of single-issue terrorism-white supremacists, ultra-nationalists, leftist revolutionaries-were analysed, for a total of eighteen. These results are summarized in the "Violent-Other" column of the table of results. Finally, an

\footnotetext{
${ }^{116}$ See page 82 of this paper.
} 
analysis of material relating to thirteen persons engaged in Islamist terrorism was conducted, with the results summarized in the line marked "Violent-Islam" of the results table. In this manner, a total of forty case histories of individuals using terroristic violence were analysed. The selection of violent cases was focussed on studies in which researchers had conducted (or utilized) interviews with the terrorists, rather than those that merely collected demographic data, not only in an effort to ensure not only a higher level of biographical accuracy, but also for internal consistency throughout the theory testing process.

\section{Non-violent Case Studies}

Non-violent case subjects were chosen in reference to the violent case subjects, in a loose attempt at 'matching' violent and non-violent activists. Historical sources, especially archival newspaper materials, were consulted to develop a list of activists and groups that were active in the 1980s alongside Direct Action, and efforts were made to contact these people for interviews. Current members of 1980s-era activists groups were also canvassed. The search for interview subjects was expanded as violent activists biographical material was discovered, so that a cross-section of both violent and non-violent activists engaged with similar issues was constructed. Eventually, a total of ten nonviolent activists were interviewed, representing a variety of groups and issues including nuclear weapons/energy, fossil fuels/renewable energy, anti-war and anti-poverty/racism. 


\section{Interview methodology}

In order to ascertain whether any or all of Munson's theory was applicable, non-violent case subjects were interviewed using a semi-structured interview format, the questions posed focusing on the subject's life history, political beliefs, general activism and specific anti-nuclear activism. Questions ${ }^{117}$ were omitted or expanded upon as the interview unfolded, or revisited in further detail if warranted. At the conclusion of the interview, subjects were asked what they felt the interviewer should have asked, or what was important but hitherto undiscussed, and their replies noted. Interviews were conducted via telephone, Skype or in person, and audiotaped by the interviewer.

\section{Non-interview methodology}

Efforts were made to secure the participation of the five members of DA in the research. Although contact was made with all five, none consented to being interviewed for this study. Consequently, information about them and their activities has been drawn from open source material including other interviews, contemporaneous newspaper articles, and Hansen's book about her time in the group. ${ }^{118}$ Opinion pieces and criticism were for the main avoided, or used only to corroborate facts, because of the prejudice that often accompanies discussions of terroristic violence. For the other violent activists, not affiliated with DA,

\footnotetext{
${ }^{117}$ See Appendix 1.

${ }^{118}$ Ann Hansen, Direct Action: Memoirs of An Urban Guerrilla, Toronto: Between the Lines, 2002.
} 
previous academic and journalistic interviews with convicted violent activists were sought out and used to test Munson's theory. ${ }^{119}$

\section{Operationalization of Munson's Theory}

Munson's mobilisation framework has discrete determinative steps, making it especially important to identify if and how each step is present in the biographies of both the violent and non-violent subjects.

\section{Turning Point}

For the turning point, this step was determined to be fulfilled if the subject had, prior to their activism beginning around a specific issue, experienced a significant change in life circumstances, which Munson categorizes thusly: "changes in educational, labor, family or religious status or physical relocation to another part of the country." 120 Since Munson was able to identify such a turning point in almost $90 \%$ of his activist subjects, ${ }^{121}$ we should expect to see a similar proportionate outcome in this study before confirming its applicability. ${ }^{122}$

\section{Movement Contact}

Closely linked to the turning point is the movement contact step, in which a 'turning' person comes into contact with an activist or group. Modifying

\footnotetext{
${ }^{119}$ For a list of studies used, see Appendix 3.

120. Munson, 57. The 'physical relocation' criterion has for the purposes of this study been expanded to include international relocation.

${ }^{121}$ Ibid.

122. Munson himself did not ask questions specifically geared towards unearthing this turning point, as he didn't appreciate its significance until after his research was completed. In some ways, this study, being aware of the turning point beforehand, ought to be able to more specifically confirm or deny its importance to activist mobilisation.
} 
Munson's definition somewhat, for the purposes of this study, this step will be said to be present if the subject has, at a 'turning' juncture in their lives, direct contact with an activist group (or movement) with whom they had had no previous significant interaction ${ }^{123}$. For the terroristic violence group, contact with a person already mobilised into a violent group or movement will be considered to fulfill this step.

\section{Initial Activism}

The third step, initial activism, follows the movement contact and is a fledgling activists' debut into activism, generally with the group of initial contact. This step will be considered present if a subject, following the initial contact, is active in a tangible way (protesting, meeting, leafleting, fundraising, etc.) with that group. For the violent cohort, actions taken in support of violence, or to secure membership in a violent group (such as an initiation rite, travel abroad to train, etc.) will be considered to fulfill this step.

\section{Full Participation}

Munson's fourth and fifth steps, development of [issue-related] beliefs and full movement participation, are in this study combined into one: full participation, wherein an activist is regularly active with a group, around one specific issue, and often with a whole-life intensity, including substantial personal and social involvement in activism. This combination of steps was decided upon in part because of the difficulty in teasing out the strands of belief inherent in

123 To clarify: the individual through whom a mobilising person comes into contact with an a group may not have been previously unknown, but the group must have been, to be considered as fulfilling the Munson criteria. 
several disparate issues and time periods, and in part because of this research's focus on the utility of Munson's theory in predicting variation in activists' actions, rather than beliefs. ${ }^{124}$ This step will be considered fulfilled if an activist demonstrably focuses their activism upon one issue, group or tactical 'stream' of protest, and does not transition between different streams while involved in an issue.

For the group of individuals involved with terroristic violence, fulfillment of this step is more varied. It will be considered present if an individual plans, assists or commits a terroristic attack; leaves behind family or friends to 'go underground' with a violent group; or changes their life circumstances (moves house, leaves school, changes religions, changes jobs) in order to commit more time and resources to a violent group.

\section{Problems with the methodology}

\section{Small number of cases studied}

This research is a multiple-case study of the phenomenon of terroristic protest violence, which in effect offers the opportunity to test Munson's theory thrice: against non-violent activists mobilisation, environmentally-related violent activism and terrorism more generally. This replication increases the generalizability of the study's results as to the validity of Munson's theory itself, that is analytic generalization rather than statistical generalization. ${ }^{125}$ However,

\footnotetext{
${ }^{124}$ The extensiveness of Munson's research into pro-life activists and non-activists, conducted over several years for his doctoral dissertation, verges into the ethnographic, allowing him to discern the differences in beliefs about abortion held by both groups. Time constraints did not allow a similar "immersion" for this study.

125 Robert K. Yin, Case Study Research: Design and Methods, Beverly Hills:Sage Publications (1989): 23.
} 
both the violent and non-violent segments of the study are represented by a fairly small number of individuals. The small number of non-violent subjects is a function of the difficulty of finding suitable, willing participants; many who were invited to participate were leery of a study that in its initial stages was funded by the Canadian government, which has of late been notable for its negative view of environmental activism. The number of violent cases is complicated by the way in which previous interviewers of violent activists have tended not to focus on the more pedestrian-seeming details of life events prior to becoming mobilised, instead focussing on beliefs, ideology, etc. Some studies with larger numbers of interviewees did not reproduce sufficient transcript data to allow for testing of Munson's theory on all subjects, which introduces the risk that the 'testable' cases are not representative; the excluded cases might in fact disprove the hypotheses. In mitigation of the small sample size, however, it should be noted that Munson's theory was developed after several years of ethnographic research, during which he interviewed over 300 people, giving his findings high internal validity. As a hybrid most-likely test and plausibility probe, it could be argued that, as a investigation into the necessity for a larger future study, the number of cases involved is sufficient to determine the theory's utility, if not its general applicability.

\section{Problems inherent in interviews and autobiographies}

This study relies on semi-structured qualitative life history interviews to determine whether non-violent case subjects have undergone any or all of Munson's four steps in becoming mobilised into anti-nuclear activism. This 
presents problems for the reliability of the data derived from the interviews, which are not only focussed on events that took place more than thirty years ago, but are possibly related to the subjects' personal identification as activists. These problems are heightened when considering the information gleaned from interviews or autobiographies of 'terrorists,' who are more likely to "reconstruct their participation [in terrorism] in especially favourable terms ... or use their autobiographies to pursue political ends, sensationalize events, and rationalize prior actions to governments, their constituencies, other terrorist groups, and themselves." ${ }^{126}$ In mitigation, is must be noted that the information required to test Munson's theory is less likely to be 'massaged' by subjects, as it is concerned not with ideology, justification or personal mythology, but rather mundane details such as residence or schooling.

${ }^{126}$ Mary Beth Altier, John Horgan and Christian Thoroughgood," In Their Own Words? Methodological Considerations in the Analysis of Terrorist Autobiographies," Journal of Strategic Security 5, no.4 (2012): 93. 


\section{Chapter 5: 'Direct Action'}

\section{Why Direct Action?}

The violent case subjects for this study are the members of a Canadian terrorist group: 'Direct Action' also known as the 'Squamish Five,' active in British Columbia and Ontario in the early 1980s. The selection of Direct Action as a case study was based on several factors, including the general lack of academic information on the group, the diversity of the protest issues that DA engaged with, and the relevance of their actions to CT policy in Canada today. ${ }^{127}$ Although they were not charged with terrorism-related offences at the time of their arrests, their actions can be considered terrorism under current Canadian criminal law, which defines terrorist activity as an act

(i) that is committed

(A) in whole or in part for a political, religious or ideological purpose, objective or cause, and

(B) in whole or in part with the intention of intimidating the public, or a segment of the public, with regard to its security, including its economic security, or compelling a person, a government or a domestic or an international organization to do or to refrain from doing any act, whether the public or the person, government or organization is inside or outside Canada, and

(ii) that intentionally

(A) causes death or serious bodily harm to a person by the use of violence,

(B) endangers a person's life,

(C) causes a serious risk to the health or safety of the public or any segment of the public,(D) causes substantial property damage, whether to public or private property, if causing such damage is likely to result in the conduct or harm referred to in any of clauses $(A)$ to $(C)$, or

(E) causes serious interference with or serious disruption of an essential service, facility or system, whether public or private, other than as a result of advocacy, protest, dissent or stoppage of work that is not intended to result in the conduct or harm referred to in any of clauses $(A)$ to $(C) .128$

\footnotetext{
${ }^{127}$ Given the tendentious politics surrounding the development of the Northern Gateway pipeline, for instance, it is a not unreasonable prediction that a group similar to DA will surface in the next few years.

${ }^{128}$ Criminal Code of Canada RSC 1985, c-C46, s 83.01(1)
} 
In various configurations, Direct Action was responsible for a series of extralegal protest actions against several targets. Some were little more than vandalism dressed up with a manifesto, while others resulted in severe injuries and millions of dollars in damage. The diversity of their targets-mining companies, pornography shops, defence contractors-means that DA cannot be neatly described as 'ecoterrorists,' nor 'anarchists' or 'left-wing terrorists' in the European mould. ${ }^{129}$ They self-identified as revolutionaries, suggesting a left-wing analysis, but their bombing of the Cheekeye-Dunsmuir power transmission station, for instance, would define their motivations as "reformist" under Crenshaw's 1981 framework ${ }^{130}$, as an example of "terrorism resulting from the actions of groups designed to stop particular practices." ${ }^{131}$

The five members of Direct Action (DA) were: Brent Taylor, Ann Hansen, Doug Stewart, Gerry Hannah and Juliet Belmas. Little is verifiably known about the pre-DA lives of two of its members, Brent Taylor and Doug Stewart. The two men lived together in Vancouver prior to the group's 'founding' 132 in 1981-1982. Hansen, who had met Taylor previously while living in Toronto, moved to

\footnotetext{
${ }^{129}$ There is an ongoing debate as to the validity of conflating property-directed acts such as those carried out by groups like the Earth Liberation Front with those person-directed acts such as the $9 / 11$ attacks. This paper will not engage in the debate, with the exception of using terminology such as "terroristic violence" in lieu of terrorism, because of the suggestion that terrorism is better understood as a strategy or series of interconnected acts, and less useful in understanding single occurrences. As well, members of DA and other violence-using activists will not be referred to as "terrorists" because of the pejorative and often partisan way in which the term is used.

${ }^{130}$ Martha Crenshaw, "The Causes of Terrorism," Comparative Politics 13, no.4 (1981): 385.

${ }^{131}$ Rachel Monaghan, “Single-Issue Terrorism: A Neglected Phenomenon?” Studies in Conflict and Terrorism 23 (2000): 256.

${ }^{132}$ In single quotation marks to indicate that nothing so formal as a founding event ever took place, but rather a jelling of a looser affiliative network around several actions.
} 
Vancouver in 1980, which set the group in motion. Belmas joined later, bringing Hannah with her.

\section{Direct Action: A timeline}

\section{1}

The group of friends who would later become Direct Action started their revolutionary campaign slowly, in part because initially, while there was a larger number of people who might support the occasional monkeywrenching expedition, there was only Taylor, Stewart and Hansen who "showed great commitment not just to the theory of militancy but also to a desire to be a militant." ${ }^{33}$ Their plan was to embark on a series of smaller actions that would awaken a 'revolutionary consciousness' in their friends and fellow activists, while also procuring some of the false documents, weapons and tradecraft that life underground might require. ${ }^{134}$ Their first target was the Amax mining corporation, whose activities were reportedly polluting the air and water in traditional Nisga'a territory near Prince Rupert, B.C ${ }^{135}$; the action consisted of glass jars filled with red paint and rotting fish thrown through the broken window of the Amax headquarters. For their next attempt, in which they were joined by Belmas-as a sort of probationary action before accepting her in the group-they

\footnotetext{
133 Hansen, 26.

${ }^{134}$ Ibid.,40. This included some ingenious ploys to wrest personal information needed to obtain social insurance numbers, and thus driver's permits; thefts of typing supplies, shoplifting of groceries and camping supplies, etc. At this point, Hansen, Taylor, Stewart and many of their non-DA allies live almost entirely on social assistance and thieving.

${ }^{135}$ Ibid., 40. Amax Corp. was apparently Stewart's pet project; Hansen, being from Ontario, was unaware of the issue until Stewart brought it up. The mine is set to re-open, as the price of molybdenum has made the high cost of extraction at the site justifiable. (see http:// www.ceaa.gc.ca/o50/documents/55933/55933E.pdf ) As in the 1980s, there is Nisga'a opposition to the mine.
} 
spray-painted the building with "Amax Kills" and "Resist Corporate Greed" and again phoned in a communiqué. They reprised their actions, with the addition of signal flares, targeting a building housing the provincial ministry of the environment in Victoria.

After these tentative steps toward militancy, the group pursues a Europeanstyle underground revolution in earnest. They steal a small car, and Hansen receives a legal Firearms Acquisition Certificate (FAC) and purchases a Ruger Mini-14 assault rifle; soon the group is heading into the mountains near Squamish for target practice. ${ }^{136}$ Stewart locates a source of explosives for the group-the Department of Highways, which stores its blasting supplies in magazines along the Sea-to Sky highway between Vancouver and Whistler-and the group steals several hundred pounds of a stable explosive compound called Toval. Like the proverbial carpenter and his hammer, they soon begin casting about for problems requiring an explosive solution: "although we had no specific plans for the [Toval,] just knowing it was in our possession inspired more discussions around possible future actions." ${ }^{37}$ Soon after, the group steals an arsenal from the home of a local gun enthusiast: handguns, rifles and shotguns, eventually filling "laundry baskets so full of weapons we could barely see over them to walk." ${ }^{38}$ In order to test their plans of becoming underground guerrillas, Taylor, Hansen and Stewart move to Calgary to live anonymously, sharing a

\footnotetext{
${ }^{136}$ Hansen, 109.

137 Ibid., 138.

${ }^{138}$ Ibid., $143 ;$ R. $v$. Belmas details the 12 weapons stolen, along with their accessories and ammunition, para 8 .
} 
nondescript apartment and planning their future attacks. The stress of living in isolation prompts the three to return to Vancouver to plan the Cheekeye action after only a few months, despite the danger of being discovered by police. ${ }^{139}$

\section{2}

Returning to Vancouver, the newly-christened Direct Action isolate themselves from their larger community, including the peaceful opposition groups they had previously been a part of. ${ }^{140}$ Hansen and Taylor, while still involved with their 'civilian' lovers, begin a sexual relationship with each other, which they decide to keep secret from Stewart, lest he decide not to go underground with them. ${ }^{141}$ Their plan for the Cheekeye action-explosives placed carefully to ignite the oil in the shunt reactors- is timed for just as the station was nearing completion, that would "do substantial physical damage that would delay construction and make the line less financially feasible ... [and] cause investors and politicians to think twice about supporting [similar] projects.” ${ }^{142}$ Once the attack is finalized for May $31^{\text {st }}$ Taylor, Stewart and Hansen set about writing their communiqué, "the most important part."143 Stewart and Hansen, accompanied by several hundred pounds of explosives, detonator cord and

\footnotetext{
${ }_{139}$ The group had been aware of police surveillance of the radical protest community for some time.

${ }^{140}$ Hansen, 178.

${ }^{141}$ In Hansen's memoir, she paints this as having been brewing since they first met in 1980, and sealed in their time in Calgary; Taylor has been more circumspect in interviews.

${ }^{142}$ Hansen, 186. This indicates how DA's actions fulfill the terrorism criteria of having an intended audience beyond the immediate target, and of intending the action to act coercively on said audience.

143 Ibid., 196.
} 
timing devices, take the passenger ferry to Nanaimo, and place the bomb, setting it to go off early the next morning, by which time they had returned to Vancouver. $R . v$. Belmas describes the resultant scene:

The sound of the explosion was heard 30 miles away. There was great damage. Four shunt reactors weighing approximately 109 tons each were damaged extensively ... two of the eight fires took 10 days to burn out. The force of the explosion moved these reactors as much as six inches from their original positions on concrete pads... One piece [of steel] weighing approximately 110 pounds was thrown some 600 feet by the explosions. The total damage was estimated at $\$ 3,781,816.00^{144}$

Although the communiqué was received by the media, and a $\$ 125,000$ reward for information offered by BC Hydro, police are unable to trace the bomb to Stewart and Hansen. The RCMP interview several hundred activists and "even those who had expressed strong opinions against Hydro's expansion,"145 including an NDP MLA, to no avail.

While Stewart and Hansen had been planning and committing the Hydro bombing, Taylor had been busy assessing the feasibility of an attack on the Litton industries plant in Toronto. Litton was seen by the group to be an excellent target because of the large, non-violent opposition movement already in place, and "polls showed that the general public was opposed to Canada's role in the development of the cruise missile." ${ }^{146}$ The public interest in the issue was important, because the group felt the reaction to the Cheekeye-Dunsmuir bombing had been disappointingly muted. Another dynamite theft ensues: 2,000

\footnotetext{
${ }^{144}$ R. $v$. Belmas para 10.

${ }^{145}$ Sid Tafler, "Environmentalists, MLA, reporter investigated: B.C. Hydro station bombers elude police," Globe and Mail 20 September 1982.

${ }^{146}$ Hansen, 186. See also John Clearwater, Just Dummies: Cruise Missile Testing in Canada, Calgary: University of Calgary Press, 2006.
} 
pounds stolen, once again not for a specific action but because "we would need more dynamite no matter what we planned to do."147 They spend August "studying the anti-nuclear issue and the cruise missile in particular," 148 and drive to Toronto, in a truck filled with dynamite, in September. The details of the plan -where and how to plant the bomb-were to be fleshed out once they arrived.

In Toronto, they rent an apartment, where they store the dynamite in the living room, as well as a garage for their truck and subsequently-stolen van. ${ }^{149}$ They monitor the plant, and determine that there are workers on the premises twenty-four hours a day; moreover, they cannot establish where, precisely, the cruise missile components are manufactured, reducing the likelihood both of a 'clean,' casualty-free explosion and a meaningful, well-understood attack symbolism..$^{150}$ Nonetheless determined to press on with the bombing, the trio work on ensuring the accuracy of the timing device. ${ }^{151}$

The night of the bombing, they drive the van full of explosives up to a building, and place an orange cardboard box with "DANGER EXPLOSIVES"

\footnotetext{
147 Hansen, 226.

${ }^{148}$ Ibid., 239; the study was necessary because Stewart, who was not participating in the bombing, was the only DA member with an extensive background in peace and anti-nuclear activism.
}

${ }^{149}$ Ibid., 246. Belmas would later allege in the EF! interview that sleeping in close proximity to the dynamite caused her to suffer nitrite poisoning.

${ }^{150}$ Ibid., 248.

${ }^{151}$ Hansen makes it clear in her memoir that the possibility of casualties from the night shift workers is considered, and accepted as necessary. This is in sharp contrast to the various attacks by ELF-type groups, which have not caused human harm, and also to the group's after-bombing communiqué, which places the blame for the casualties on a faulty timer and slower-thanexpected police response times. That communiqués states that "we took great care in preparing what we seriously assumed were adequate precautions to insure the safety of all people in the are," and that "we feel it is undeniable that all injury to the workers could have been avoided if the guards had promptly evacuated the Litton plant, as they obviously should have." From "Statement regarding the October 14 Litton Bombing," Appendix 2, Hansen, 347. 
written on it, and a set of printed instructions designed to prevent security from tampering with the van. ${ }^{152}$ Belmas calls the police at 23:18 with instructions, ${ }^{153}$ but has trouble making herself understood. Although DA would claim that the timer was set for 23:43, the bomb explodes at 23:30, injuring at least seven people, and causing an explosion that shook houses three kilometres away from the blast site; "Half of the front of the [Litton] building on City View Drive in Etobicoke was blown out, scattering chunks of rock across the road and onto Highway 27."154 The area in which the cruise missile guidance systems were manufactured is not damaged in the explosion. ${ }^{155}$

The severe injuries sustained by the Litton employees and police alarm the DA members, and Belmas flees to Vancouver almost immediately after, leaving Taylor and Hansen to craft a nine-page communiqué-cum-apologia. Condemnation of the bombing is swift, and comes from law enforcement, the media, and in particular from the non-violent anti-nuclear movement.

\section{Winter 1982-1983}

Once back on the West Coast, despite some brewing personal conflict within the group, plans are soon afoot for the robbing of an armoured car-a Brink's

\footnotetext{
${ }^{152}$ Hansen, 261.

153 Jock Ferguson and Lorne Slotnick, "Litton blast called work of experts," Globe and Mail 16 October 1982. Slotnick and Ferguson were responsible for linking the Litton communiqué with writing by DA in a Vancouver anarchist newsletter.

154 “Blasts rocks Litton plant, 7 injured," Globe and Mail 15 October 1982.

155 Edward Clifford, "Litton assembly areas undisturbed by blast," Globe and Mail 16 October 1982.
} 
guard seen picking up deposits from the local Woolco's. ${ }^{156}$ Meanwhile, connections are made between the Litton communiqué and the Vancouver anarchist community, and through them to Stewart and the other DA members; they are soon under police surveillance. The five members are watched while they plan the attacks on Red Hot Video, which was known to be a possible target of violence. ${ }^{157}$ The decision is taken to 'bug' the house in which Belmas, Hannah, Hansen and Taylor are living. Wiretap evidence hears them discussing the Litton and Cheekeye bombings, as well as planning for future actions against aircraft on a military base and an armed robbery of a Brinks truck. They are arrested while on the Sea-To Sky Highway on January 2oth 1983, tried and convicted in 1984 of a wide range of crimes, and sentenced to between 7 years and life in prison. All five members have since been released from prison.

\section{Direct Action In Context}

"We're not just opposed to pollution, nuclear technology and all that stuff. We're opposed to the entire lifestyle and values of this society." ${ }^{158}$

From their own writings, we see that the members of 'Direct Action'young, white, some from the petit bourgeoisie, some already petty criminalsidentified themselves as belonging to a global anti-capitalist revolution, spiritual siblings of the Red Brigades, the Red Army Faction, and Action Directe. The

\footnotetext{
${ }^{156}$ Hansen, 284. Woolco's was a lower-end BC department store chain, where the group had previously 'cased' for robberies.

${ }^{157}$ At the time, Red Hot Video was the focal point of a campaign against hard-core pornography that showed violence against women and girls. There had, by the time of the DA/Wimmin's Fire Brigade arsons, been a coordinated push by several women's groups in $\mathrm{BC}$ to have the video outlets sanctioned under existing obscenity laws, to no avail.

${ }^{158}$ Hansen, 65 (emphasis mine.)
} 
guerrilla struggle against right-wing dictatorships in Latin America had on them the galvanizing effect they had on many on the political left of the time, and 'urban guerrilla' was how they styled themselves."La lucha continua," wrote Brent Taylor following his arrest, "campaneros, our hideout was warmed by the knowledge of you," drawing an explicit, and apparently un-ironic ${ }^{159}$ line between his actions and those of guerrillas in "El Salvador, Honduras and Guatemala."160 While the individual ideologies of the DA members were diverse - Belmas, for instance, stated in an interview that "I was attracted to being a real life bad girl devoted to drugs, guns and fucking in the streets! That's what made me want to become an urban guerrilla, not some rigid political ideology"-161 the group adhered to an antiestablishment worldview through which they filtered their actions' intended impact. Doug Stewart's writings on the alienating effects of technology ${ }^{162}$ bring to mind the Unabomber's manifesto, and Brent Taylor drew a

\footnotetext{
${ }^{159}$ It is evident that the actual life histories of the members of DA were irrelevant to their selfconstructed identities as worker-revolutionaries. Taylor's parents were both university professors, and he grew up in the wealthiest neighbourhood in Victoria, although his Facebook profile lists his hometown as decidedly blue-collar Nanaimo, BC. Hansen attended university, even travelling abroad for six months during her studies, while Stewart completed a degree in science. A pamphlet issue in support of DA after their arrest indicates that their supporters, too, were confused as to the groups' true identities: it discusses at length the difficulty of achieving true justice when "the working class [sic] defendant has all the cards stacked against him/her" and that lawyers, who "are educated in the same private school and prestigious universities as members of the power elite ... will naturally treat more sympathetically a member of their own social standing," which it is clear the author takes to not mean the members of DA. From "Writings of the Vancouver Five," 1984, digital copy at http://contentdm.library.uvic.ca/cdm/ref/ collection/collection8/id/247
}

160 Brent Taylor, "Victory or Death," Writings of The Vancouver Five, Toronto: Toronto Anarchist Black Cross (198*) digital copy at http://contentdm.library.uvic.ca/cdm/ref/collection/ collection $8 / \mathrm{id} / 247$

${ }^{161}$ From Comrade Black, "Militant Feminism: An Explosive Interview with a KKKanadian Urban Guerrilla," Earth First! Journal 30, no. 3( April 2010): 14-16. (Hereafter “Earth First! Interview.”)

162 Doug Stewart, "Living in Reality," Writings of The Vancouver Five, Toronto: Toronto Anarchist Black Cross (198*) digital copy at http://contentdm.library.uvic.ca/cdm/ref/collection/ collection $8 / \mathrm{id} / 247$ 
direct comparison between himself and Kaczynski. ${ }^{163}$ Stewart's writings reveal him to be a deep ecologist, ${ }^{164}$ very concerned with the welfare of the non-human ecosystem, as well as of the world's oppressed peoples: he mourned that people "do not really identify with the foxes and the flowers, with the whole indescribably complex, interconnected, and beautiful life of the land; nor do we truly feel the horror and injustice of the slaughter being perpetrated against the earth." 165

Hansen had spent time in Europe living with members of the Red Army Faktion support network, and longed to be able to participate in a similar movement once home in Canada; her writings more closely resemble the European Marxist terror groups', with their shared emphases on 'analysis' and 'capitalism.' 166 Hansen describes DA's bombings as "not issue oriented actions, but [rather] our resistance politics turned into actions." ${ }^{167}$ Taylor, arguably the lynchpin of the group, shared Hansen's revolutionary mindset, placing the groups actions as part of a necessary "popular revolutionary struggle [so that] people can take control over the direction of our societies from the greedy and powerful and

\footnotetext{
${ }^{163}$ Interview with "Rosie" Rowbotham for PrisonTV, 1995. Part 1 available at http:// www.youtube.com/watch?v=W2EwkTnYf1c; Part 2 at http://www.youtube.com/watch? $\mathrm{v}=4$ WwuzhvRkn8. (Hereafter "PrisonTV Interview.")

164 As in, a believer in a worldview or philosophy first developed by philosopher Arne Naess, in which humans are no more important than non-human animals, and the biosphere has an intrinsic worth independent of its usability by mankind.

165 Stewart, "Living in Reality."

${ }^{166}$ See, for instance, Orsini, "STAM.”

${ }^{167}$ Ann Hansen "Statement of Resistance, June 25th 1984," Writings of The Vancouver Five, Toronto: Toronto Anarchist Black Cross (198*) digital copy at http://contentdm.library.uvic.ca/ cdm/ref/collection/collection8/id/247
} 
thus begin to build truly just ones." 168 All of the members of DA identified as feminists; Belmas claims that feminism, and the actions against Red Hot Video, were her primary motives in joining DA. ${ }^{169}$

Although DA saw themselves as an anarchist group, rather than Marxist, one can see in some of their writings what Orsini refers to as the dualistic or Manichean worldview, like that of the BR and RAF. ${ }^{170}$ Hansen and Taylor, at least, saw themselves as the vanguard of a revolution, as the already-awakened whose actions would cause the complacent masses to take notice and join the uprising:

"It may sound like arrogance, but I mean this in a most humble waythere are too many people in our society who have their heads in the sand regarding these enormous injustices ... And therefore I feel sorrow -not anger-in regards to the overall spiritual and moral poverty of Canadian people generally... We recognize that it is wrong to live the way we do-of the spoils of imperialism and the plunder of the earth. ${ }^{\prime 171}$

As with the Red Brigades, their revolutionary mindset rejected mere reform, and even those who campaigned for it: "We even saw some in the so-called helping professions such as social work as band-aid solutions to problems rooted in greed

\footnotetext{
168 Brent Taylor, “Statement of Resistance, June 25th 1984," Writings of The Vancouver Five, Toronto: Toronto Anarchist Black Cross (198*) digital copy at http://contentdm.library.uvic.ca/ $\mathrm{cdm} / \mathrm{ref} /$ collection/collection8/id/247

${ }^{169}$ Earth First! interview. If Hansen's accounts are accurate, this cannot be true, as Belmas joined long before the Red Hot Video actions were planned.

170 Orsini, "Red Brigades” Chapter 2.

${ }^{171}$ Taylor, "Statement of Resistance" (emphasis added.) Compare this with BR members' writings in which "no one, except the Red Brigades are aware of this [world oppression], because the 'system' plays with its victims." Orsini, "Red Brigades," 13. The word 'victims' here is particularly telling; DA members saw themselves as acting on (unasked) behalf of, among others, First Nations. The group was apparently unaware of the racism, imperialism and denial of agency inherent in the assumption that First Nations would need "saving" by white middle-class people living in voluntary quasi-poverty while claiming 'solidarity' with disenfranchised urban aboriginals. See Hansen, 67 for a particularly egregious example of this.
} 
and materialism. How could we help poor people survive when we saw the real solution to poverty as a total revolution of the economic system and the values upon which it was based?" ${ }^{172}$ Left-wing politicians and labour organizations were also deemed complicit in the unjust system: "Unions are fighting for the workers to acquire more stuff, they're not fighting to change the premises upon which this society is based. They are far from revolutionary." ${ }^{173}$

It is impossible to predict the trajectory of DA had they not been arrested, although their plans already under consideration when interrupted-armed robbery of a Brinks truck, bombing jet fighters at a Canadian air force basesuggest that their initial reluctance to risk human harm was being rapidly overcome. Orsini sees ideological dualism making it easier for the BR to kill, ${ }^{174}$ and there is in Hansen's writings a suggestion that she was engaging in similar black and white thinking, and thus potentially lethal: "I realized the real reason lay in my intolerance for anyone whose views were not similar to mine."175 Interestingly, this way of thinking is not generally shared, at least in public, by most militant environmental activists, who take pains to explain their aversion to causing physical human harm, focussing instead on economic or psychological harm. It is in the writings of some militant animal rights activists that we see echoes of the disregard for human life held by the European left-wing terrorists, because for some the refusal to use violent means against 'animal abusers' is

\footnotetext{
172 Hansen, 48.

${ }^{173}$ Ibid., 66. Attributed to Taylor.

174 Orsini, "STAM," 67.

175 Hansen, 53.
} 
blatant speciesism. ${ }^{176}$ A similar logic informs those who support the supposed defensive killing of abortion providers. ${ }^{177}$

\section{Actions Before Beliefs}

A cursory look at the group Direct Action and their activities might give the false impression that they were indeed what law enforcement and security services warn of, a 'radicalised fringe' of a legitimate protest movement, who have become frustrated with legal methods and have turned to terroristic violence. It is true that the members of DA were themselves involved with a wide array of social justice issues, from prison reform to feminism; however, it is also clear, even from Hansen's own accounts, that the particular issues they used terrorism to further were first selected for their suitability for 'consciousness-raising by dynamite,' and then studied in depth and adopted as causes by the group.

For instance, while they were involved in the non-violent resistance to the Hat Creek dam and hydro projects, organizing a conference and producing political critiques and informational pamphlets ${ }^{178}$, it was not there that they planted explosives, but rather in another part of the province, in a part of another Hydro project. Hansen made it clear that it was the action, not the issue, which was paramount. They went looking for a public venue for their revolutionary

\footnotetext{
${ }^{176}$ A gateway to the debate over non-violence within the movement can be found at http:// www.animalliberationfront.com/index.html It is noteworthy that while many AR activists might support the morality behind targeting people involved in research on animals, most view it as tactical counterproductive; this view is shared by many with the ELF umbrella of activism, as well. See this reasoned paper from an Earth First! member decrying harsher ecotage tacticsinteresting, given EF! is the alleged "birthplace" of the ELF. http:// earthfirstnews.files.wordpress.com/2010/05/rik-scarce-end-ecotage-10-2010.pdf

${ }_{177}$ See, for example, http://www.armyofgod.com

${ }^{178}$ Hansen, 121.
} 
message, an issue for which there was already a mature opposition movement in place: "issues that had attracted popular support but had exhausted all legal avenues of opposition," in their opinion. ${ }^{179}$ They selected the CheekeyeDunsmuir transmission line as a target, and chose the Dunsmuir substation on Vancouver Island for its remoteness and ease of access, ${ }^{180}$ not for its personal resonance to the group members. The target was intended to represent opposition to the Hydro megaprojects as a whole, anticipating such an action would be "popular and easily understood ... because the legal struggle has failed, in the sense that the line is now under construction." ${ }^{181}$

Similarly, the decision to bomb the Litton Industries plant was not the anguished last resort of a group of committed protestors, but a calculated targeting based on a media story Taylor brought to the group's attention. Indeed, DA members were not a part of the existing non-violent protest movement that had already been pressuring Litton (and the Canadian government) to 'refuse the cruise' for several years before the bombing-a movement which wholly rejected

\footnotetext{
179 Ibid., 139.

${ }^{180}$ It is interesting that, of all the Hydro megaprojects that the members of DA had been active in opposing, they chose to attack the C-D transmission line. Hansen's memoir is full of apparent concern for the impact of the Hat Creek generation projects on the traditional way of life of the First Nations in the vicinity, and for the environmental effects of the coal mine and coal-fired generating plant. The C-D transmission line would have a greater effect on the mostly-white landowners who had their land appropriated for the line cuts, and the environmental impact was related to the spraying of pesticides and defoliants along the line cut. I believe this speaks to the validity of Munson's de-linking intensity of beliefs and actions, and exposes DA as carrying a false flag for activism: their targets were opportunistic, not passionate.

${ }^{181}$ Hansen, 169.
} 
DA's actions as both harmful to Litton workers as well as contrary to their espoused non-violence. ${ }^{182}$

DA member Doug Stewart had previously been active in a non-violent antinuclear group in Vancouver, and several DA members had planned and attended anti-nuclear rallies, but the cruise missile issue in general, and Litton's role in it, was not something that DA had mobilised around, nor had it been very relevant to the anti-nuclear movement on the West Coast, which has tended to focus more upon opposition to US Navy weaponry and nuclear-powered warships. ${ }^{183}$ A cynic might argue that Direct Action, having decided to blow something up in furtherance of their revolutionary ideals, had merely cast about for the most high-profile target, rather than an issue about which they were longstanding, passionate activists. They had not changed tactical streams, but rather changed issues.

It is important to note that while law enforcement might disagree, there is a wide gulf between actions that might damage a building or equipment, and those that could harm people. It is clear that DA remained a small group not by choice, but through the difficulty of attracting other activists to their militant ways in part because of this gulf. Hansen noted that they had many more volunteers for their vandalism raids against Amax than for their bombings, and that, in spite of

\footnotetext{
${ }^{182}$ My interview with a former member of the anti-cruise movement confirmed this condemnation, as well as the suspicion and surveillance that the movement fell under after the bombing. Even thirty years later, she was aghast at the damage done by the bombing, not only to the injured employees, but to the cause itself. In her opinion, absolutely nothing good came of DA's actions, however noble their intentions.

${ }^{183}$ At the time of the Litton bombing, anti-nuclear activists on the West Coast had already begun adopting non-violent radical direct action techniques in protest of US military weapons, influenced by the Ploughshares movement.
} 
the extensive non-violent opposition to BC Hydro's various megaprojects, the DA members "were coming to the conclusion that there were no other people ready to participate in any serious guerrilla actions." ${ }^{184}$

\section{Violent case studies: 'Direct Action'}

\section{Ann Brit Hansen}

The daughter of Danish immigrants to Ontario, Hansen described her childhood in a semi-rural area outside of Toronto as "idyllic:" "no substance abuse, physical abuse, emotional abuse." ${ }^{185}$ She is the eldest of five children, and her father died when she 16 or seventeen. ${ }^{186}$ As an adolescent, she was successful socially and academically, a cheerleader. ${ }^{187}$ She describes the transformation of her rural suburb from farmland to industrial park as emotionally painful for her, a pain that led her to begin to identify with the youth counterculture of $1960 \mathrm{~s}$ California. ${ }^{188}$ "Fascinated with the hippies" as a teenager, she began to develop a left-wing political consciousness in high school. ${ }^{189}$ The transition from overachieving tomboy to disgruntled hippie-wannabe caused some friction between Hansen and her parents: "I started arguing with my father about values . .. I preached endlessly about the pollution, the plight of Indians and Eskimos, (sic) my abhorrence of material things ... [I was] intolerant of anyone who didn't

\footnotetext{
184 Hansen, 136.

185 Ibid., 55 .

${ }^{186}$ Ian Mulgrew, "Down to earth with a thud," Globe and Mail, June 19th 1984.

${ }^{187}$ Hansen, 56.

${ }^{188}$ Ibid.

${ }^{189}$ Ibid., 22.
} 
share my all-consuming passion for my newfound social conscience," ${ }^{190}$ which included her parents and siblings.

Hansen studies Marxism through her university's Integrated Studies department, which allowed students to create their own learning plan, centered on their own interests. In 1979, she travelled to Europe for six months as part of her university studies, researching the left-wing terrorist groups active there, in particular the Red Army Faction. ${ }^{191}$ Her first experience while there is an encounter with a man she mistakes for a kindred radical, who is willing to trade the address of some RAF contacts in Paris for money. After offering her a place to sleep for the night, he sexually assaults her. ${ }^{192}$ The contact information he provides is genuine enough, and she stays with the French radicals for three months, where they "involve [Hansen] in all the support work they were doing for the Red Army Faction in Paris." Her time there is busy, and makes quite an impression on her:

I realized I was in a unique situation to learn first-hand about the politics and workings of an urban guerrilla group, and I worked passionately putting out leaflets, aiding RAF fugitives, and doing anything else I could. We even travelled to Stuttgart, West Germany, to attend the trial of Klaus Croissant, a German Lawyer for some RAF militants ${ }^{193}$... Although I was absorbing everything around me like a sponge, I was growing disillusioned with the RAF tactics of assassination and the injuries to innocent victims in some of their actions ... despite my criticisms, I have never felt as intellectually and

\footnotetext{
190 Ibid., 57.

${ }^{191}$ Ibid., 22.

192 Ibid., 24.

193 Croissant was convicted on 16 February 1979 of "having supported a criminal organization." From http://echr.ketse.com/doc/13611.88-en-19891208/view/ accessed 30 December 2013.
} 
emotionally alive as I did in those six months in Paris ... I did not want to go back to Canada. ${ }^{194}$

Hansen is eager to explore different facets of political action, and so attends a large trade union demonstration in March 1979. In the enormous crowd, she is drawn to a group of "autonomists ... the political version of punks-anarchists who believed in living and acting autonomously from society and government." 195 She describes them with reverence as "outlaws," shoplifting, squatting in buildings, getting their clothes from charity shops. ${ }^{196}$ She joins in with the autonomists, and is soon fleeing from police to a train station, where the autonomists erect a barricade; after several hours, the police use tear gas to penetrate the building, and Hansen is affected. Notably, she describes the situation as "probably one of the most exciting days of my life."197

The demonstration is clearly a catalyst for Hansen, and her newly-declared identity as an 'urban guerrilla' makes her reluctant to return to Canada, where she fears there will be no revolution, no militants there for her to connect with. ${ }^{198}$ Return to Canada she does, however, and soon after meets Brent Taylor via the prisoners' support newsletter the Bulldozer. Their first meeting is brief, having been thrown together to spray-paint graffiti in support of Prison Justice Day, 1980. ${ }^{199}$ However, Hansen's description of their night together blends the thrill

\footnotetext{
194 Hansen, 25-26.

195 Ibid., 26.

196 Ibid.

197 Hansen, 28.

${ }^{198}$ Ibid. 29.

199 Ibid., 13.
} 
of illicit behaviour, the frisson of getting caught, the pleasure of intellectual bantering, and, at least on her side, romantic and sexual attraction, so that by the end of the night, "I was the converted."

When a friend from West Germany visits a few months later, Hansen plans a trip to Vancouver, ostensibly to introduce her comrade to prison activist Claire Culhane. ${ }^{201}$ Hansen and her friend turn up at Taylor's house, where she meets Stewart, and two female housemates who are to be fringe associates of Direct Action. Within a few days, Hansen has accompanied the housemates on an illegal postering expedition, a large, involved shoplifting spree at a grocery store, and a break-and-enter at a welfare office: ${ }^{202}$

"I was becoming increasingly aware that [Taylor] and his friends were modern-day Robin Hoods. I'd never in my life met any group of people who lived a more complete rebel lifestyle than [them]. They lived and breathed rebellion,"203 and to Hansen, that rebellion was obviously seductive. As Hansen describes it, within a week she, Taylor and Stewart have elected themselves founders of a future militant group, with planning already underway for a series of small actions against Amax Corp.

\footnotetext{
${ }^{200}$ Ibid., 14. As patronizing and sexist as it would be to exclusively attribute Hansen's violent actions to her love interest in Taylor, her memoir makes it clear that being with him is a pivotal motivator for her.

${ }^{201}$ Ibid., 21; she admits the trip was a ruse to visit Taylor, who had extended an invitation to visit if she were to be in the area.

${ }^{202}$ Hansen, 35-37.

${ }^{203}$ Ibid. 36.
} 


\section{Brent Taylor}

Brent Taylor, the son of two university professors, grew up in a wealthy, establishment neighbourhood inVictoria, B.C. He describes himself ${ }^{204}$ as interested in counter-culture and progressive politics even as a teen, engaged with opposing the war in Vietnam and with various Third World liberation struggles. Growing up "he was athlete, with provincial high school track records to his credit." ${ }^{205}$ At one point in early adulthood he apparently announces to his parents that his "career was going to be a revolutionary." He eschews university, and travels somewhat aimlessly across Canada before settling for a time in Vancouver. There, he immerses himself in Kitsilano's bohemian drug culture, although after a few months of endless partying he is left wanting; he is eager for his life to have more depth, apparently because of the political literature he has been reading.

In an effort to find this depth, he returns home, enrols at the University of Victoria in Political Science, and contemplates joining the New Democratic Party. He describes this as his "last kick at the can" of living a "straight" life, but he drops out after the first semester, finding the university's teachings incongruent with his ideological beliefs. In the mid-1970s, to further his chosen "career," he travels to Seattle and California to make contact with the left-wing militants he reads about in a special edition of the Berkeley Bard, such as the New World Liberation Front, Weatherman and the Symbionese Liberation Army. Soon he

\footnotetext{
204 PrisonTV Interview.

205 Hansen, 11.
} 
finds himself manning a NWLF-affiliated bookstore in Berkeley. ${ }^{206} \mathrm{He}$ is arrested and briefly jailed for leftist postering in Oakland. His stated motivation for supporting such militant groups is solidarity with the poor, and he professes approval of their methodology of bombing utility companies who "gouge" their low-income customers, and shopping malls as being bastions of consumerism. He does not admit any participation in such actions, however.

After being deported from the United States because of his leftist activities, he moves to Toronto, living for a time at Rochdale College, an experimental "free college" whose academic mission had by this time devolved into mass squatting and rampant drug use. He describes himself as being "isolated" in Toronto, and "searching for stuff to do." He dabbles in various social justice campaigns, including the "Free Leonard Pelletier" movement, and works on newspapers supporting these causes.

Through this activism, he becomes aware of a Vancouver-based anarchist group and their "excellent" newsletter, and through this newspaper starts defining himself as an anarchist, rather than a Marxist. His girlfriend at the time expressed a desire to move to B.C., and so they move to Vancouver, where Taylor becomes involved with the Open Road newspaper. In 1977, he joins the Seaforth Highlanders, a militia regiment, ostensibly to gain weapons experience and training; he quits (or is discharged) after a year. Also in 1977, he is arrested after throwing a pie in the face of Prime Minister Joe Clark during a visit to the University of British Columbia, a prank he concocts as a member of the "Groucho

\footnotetext{
${ }^{206}$ All of Taylor's claims to revolutionary status are unverified, although presumably could be fact-checked by the relevant security forces.
} 
Marxists", a "radical clique composed of student activists, Yippies ... and founders of the anarchist paper Open Road." ${ }^{207}$ Hansen describes him as being active in the anti-war movement in Vancouver, part of the broader left-wing protest community that was very active at the time. As Belmas describes the milieu:

During the early '8os, there was way more social-political activity going on all around in Vancouver-much more than any time since, that's for sure: peace marches by the thousands, lots of socialism themes in the various political rallies, Rock Against Prisons every August, the Trade Union movement, general strikes, and so on and so on. ${ }^{208}$

At some point, he meets Doug Stewart, and the two become roommates. ${ }^{209}$ By the time Hansen meets him in 1980, he describes himself as living "in a communal house with a bunch of anarchists." ${ }^{210}$

\section{Juliet "Julie" Belmas}

At the time of her arrest in 1983, Juliet Belmas is 19. She is the youngest of six children, ${ }^{211}$ and grew up in Port Coquitlam, a sprawling semi-rural suburb of Vancouver, in a middle-class family. At one time, her father was a lineman for

\footnotetext{
${ }^{207}$ Scott Beadle, "Direct Action: Memoirs of An Urban Guerrilla/Guilty of Everything” (Review,) BC Studies 136(2002/2003): 147.

${ }^{208}$ Earth First! Interview.

209 There is very little known about Stewart, or his relationship with Taylor before DA. He did not reply to my request for an interview.

${ }^{210}$ Hansen, 14; these include Stewart, Taylor's girlfriend, and other women who may have been part of the Wimmin's Fire Brigade actions.

${ }^{211}$ From Earth First! Interview.
} 
BC Hydro. ${ }^{212}$ There are allegations she was sexually molested as a child. ${ }^{213}$ She describes herself as being very attracted to the "hippie" and "Punk" subcultures as a teen, and, supported by her parents whom she describes as "having seen it all" she begins dressing in punk clothes-ripped denims, leather, safety pins and neon hair-as a teenager. After quitting her manufacturing job in Port Coquitlam, she moves into a "punk house" in Vancouver proper and immerses herself in the scene, forming a punk band and producing a punk "fanzine". ${ }^{214}$ Initially, her attraction to the punk/anarchist counterculture in Vancouver is apolitical:

I just wanted to look cool. I wasn't trying to do anything like revolution at first. I know people would like to think that I was always about breaking boundaries of politics and gender, but Gerry [Hannah] and I didn't really have time for that; we were really too busy trying to pull enough money together for records, beer and the rent. ${ }^{215}$

While in Vancouver, she is "violently attacked ... by bat-wielding fascists," who apparently target her because of her clothing and lifestyle. Shaken by this event "that changed me completely," she returns to her family home and starts reading newspapers during her recuperation-something she hadn't done much of before, by her own admission. Through news stories of violent state repression in Latin America she begins to identify with the victims of such violence, drawing parallels between her attack and their oppression because of their "antiestablishment" beliefs. Hansen even describes a "newscast [that] was the turning

\footnotetext{
${ }^{212}$ Mulgrew, "Thud."

${ }^{213}$ In Lindsay Scotton “On a warm afternoon in late April 1982," Toronto Star 23 May 1985, although this is unverified.

${ }^{214}$ Beadle, “Review,"148.

${ }^{215}$ Earth First! Interview.
} 
point that had motivated her to take the first political step to join an El Salvador support group."216 Returning to downtown Vancouver, she seeks out the punk life once again, but with renewed energy: "I came right out of the suburbs with a revolutionary zeal like no other." ${ }^{217}$ She becomes romantically involved with Gerry "Useless" Hannah, a local punk bassist. ${ }^{218}$ She also begins to be politically involved in earnest. A "newscast [featuring atrocities in El Salvador] was the turning point that had motivated [Belmas] to take the first political step to join an El Salvador support group," ${ }^{219}$ where she meets Brent Taylor. ${ }^{220}$

It is clear that Taylor made an impression on Belmas, and she on him, although whether to the almost romantic extent depicted in Hansen's memoir is contested. ${ }^{221}$ In any case, within a year after meeting Stewart, Belmas is registering for a gun permit and purchasing assault rifles; she registers guns for herself and for Hannah. ${ }^{222}$ Taylor curates Belmas as his personal protégé, waiting to introduce her to the group until after "talking to Julie about politics for months, every time there's an El Salvador meeting." ${ }^{223}$ At her first meeting with

${ }^{216}$ Hansen, 9.

${ }^{217}$ The risibility of this statement should in no way diminish our understanding of Belmas's belief in its veracity; her self-identification as a militant is critical to her future violent actions.

${ }^{218}$ Beadle, "Review," 148; Hannah is as equally famous for his punk pedigree as for his DA membership.

${ }^{219}$ Hansen, 9.

${ }^{220}$ Earth First! Interview; there is some confusion about the dates when she first met Taylor and became active with DA. In her EF! Interview, she states she began acquiring firearms after meeting Taylor in 1981.

${ }^{221}$ In her interview for Earth First! Magazine, Belmas rejects the portrayal of herself as Hansen's romantic rival.

${ }^{222}$ Earth First! Interview; also Hansen, 56.

223 Hansen, 78. 
Hansen, Taylor brags about the Amax vandalism, and then suggests to Stewart and Hansen that he invite Belmas to go along on their "action," to which they agree. ${ }^{224}$ An habitual shoplifter, ${ }^{225}$ Belmas is already familiar with illegal activity when she joins Hansen and Taylor on a trip to Vancouver Island where they vandalized a Ministry of Environment building with paint and signal flares. ${ }^{226}$ Vandalism "gave her a sense of power and made her feel less helpless."227

In 1981, Belmas and Hannah move to Jasper, Alberta, to seek a rural life together, but return to Vancouver in 1982, after finding Jasper less of an idyll than expected. ${ }^{228}$ While in Jasper, Belmas had been sexually harassed by her boss, who subsequently committed suicide. Belmas allegedly felt "as though everyone in Jasper hated her," ${ }^{229}$ prompting the move home. Hansen describes it thusly:

[Belmas and Hannah] were at a crossroads in their lives, searching for new identities and dreams. [Hansen and Taylor] were there to fill the void and guide them down the road towards becoming urban guerillas. ${ }^{230}$

At her sentencing appeal, the court described Belmas as a joiner, a follower:

"Belmas was performing the role of a soldier and willing participant at the time of

\footnotetext{
224 Ibid. 79.

${ }^{225}$ Hansen's memoir is filled with references to Belmas' habit (e.g. p 83), and Belmas was re-jailed shortly after her release from prison, for violating her parole by shoplifting.

${ }^{226}$ Hansen, 84 .

227 Ibid., 225. Also Earth First! Interview.

${ }^{228}$ John Mackie, "Ex-urban guerrilla did it his way,” The Windsor Star 10 August 1995.

${ }^{229}$ Hansen, 145.

${ }^{230}$ Ibid. 146.
} 
these events, but she was not in control nor was she a leader," ${ }^{231}$ although interestingly, the judge singles out Hansen as the major influence on Belmas' DA participation, not Taylor. ${ }^{232}$

\section{Gerald “Gerry Useless” Hannah}

Hannah, in his early twenties when arrested, grew up "the youngest of five children in a tight family”233 in Burnaby, B.C, outside Vancouver. Hannah's father, a fundamentalist Christian, died when Hannah was ten. He remains close to his mother, who supported his ends, if not his means. ${ }^{234}$ He grew up going to church regularly, and even attended a Christian summer camp, where he learned to shoot. ${ }^{235}$ As a child, and later as an adult he apparently showed great affinity for nature, camping and general outdoorsmanship.

Hannah dropped out of high school in Grade 11, ${ }^{236}$ moved to Vancouver and shortly thereafter, in 1978, with some childhood friends, he founded "legendary punk band the Subhumans," ${ }^{237}$ the backbone of Vancouver's burgeoning punk scene. The Subhumans quickly develop the reputation as a 'political' band,

\footnotetext{
${ }^{231}$ R. v. Belmas (1986) para 44.

${ }^{232} R . v$. Belmas para 56.

233 Mulgrew, "Thud."

${ }^{234}$ Howell, citing Glen Sanford's documentary Useless (2001).

235 Mike Howell, "Political Convictions," Vancouver Courier, 31 July 2005.

${ }^{236}$ Mulgrew, "Thud."

237 John Mackie, "Ex-urban guerrilla did it his way," The Windsor Star, 10 August 1995. The use of the term 'legendary' seems justified by the devotion of the band's fanbase who, even after thirty years and several changes in membership lineup, were attending the band's tour performances as late as 2011.
} 
playing at anti-nuclear protests ${ }^{238}$ and penning singles like "O Canaduh," "Urban Guerrillas" and "Hiroshima." 239 In this punk foment, he meets Juliet Belmas, herself a punk musician and scene follower, and they become romantically involved. By all accounts, Hannah's devotion to Belmas is his pathway to Direct Action, although he had met Taylor through his music, as the Subhumans apparently played any of the political benefits and demonstrations that Taylor and Stewart organized or attended. ${ }^{240}$

When Hannah is floated as a potential member of DA, the initial reaction is mixed: Taylor is enthusiastic, but Stewart doubts Hannah's maturity and commitment: “I'm not impressed with what I've seen of them ... they're [Hannah and Belmas] a couple of punk kids who say a lot of rabid shit, but I'm not convinced they know what they're talking about." ${ }^{241}$ Hannah remains on the sidelines, not accompanying Belmas on the Amax actions, but joining in on some of the Squamish target practice sessions. ${ }^{242}$

In 1981, "disillusioned with the punk scene and deeply in love with [Belmas] he quit[s] the Subhumans,"243 and shortly thereafter moves to Jasper, AB with Belmas. In Jasper, he works at the Marmot Basin Ski Resort. ${ }^{244}$ When he and

\footnotetext{
${ }^{238}$ Lindsay Scotton “On a warm afternoon in late April 1982," Toronto Star 23 May 1985.

239 http://subhumans.ca/discography/

${ }^{240}$ Hansen, 75 .

${ }^{241}$ Ibid., 79; attributed to Stewart.

${ }^{242}$ Ibid., 110.

243 Mackie, "His way."

244 Although Hansen makes no mention of it, either Hannah or Belmas make use of his job to steal tools an communications equipment valued at $\$ 17,000$, property which is subsequently found at the "underground" house shared with DA, following their arrest. R. v. Belmas, paras 16-17
} 
Belmas return to Vancouver the next year, she is keen to become more involved with Taylor, Stewart and Hansen, while Hannah is more circumspect: "Hannah hunkered down with his synthesizer, intent on composing music for films" while "[Belmas] got more and more involved." 245 It is at Belmas' urging that he becomes more involved with DA, chiding him for his apparent lack of commitment to the revolution, until:

I ended up selling my synthesizers and buying an assault rifle with the money. I know it sounds ridiculous, but it is the truth. And [Belmas] and I stated working as a team, going out together and spraypainting and doing other small political actions ... [After hearing that Stewart, Taylor and Hansen had bombed the Hydro substation] I decided at that point I wanted to help, that I wanted to be in a support role to what they were doing ... but I didn't want to go underground. I didn't want to devote my entire life to being an urban guerilla. ${ }^{246}$

His court testimony confirmed his reluctance to become fully involved with DA, ${ }^{247}$ but ultimately does so, because "[Hannah] was a victim of his love for [Belmas] ... quite willing to give up his life, not for a political cause, but for [Belmas,] and if that meant becoming an urban guerrilla, so be it.” ${ }^{248}$ Once Belmas decided to go underground following the Litton bombing, Hannah felt he had to accompany her: "In fact [Belmas] said to me, 'Look, we're going underground and either you come with us, or that's the end of the relationship.'

\footnotetext{
245 Mackie, "His way.”

${ }^{246}$ Mackie, "His way."

247 Mulgrew, "Thud.”

${ }^{248}$ Hansen, 146.

${ }^{249}$ Howell, "Political Convictions."
} 
So I went with them."249 At his sentence appeal, Hannah is identified as being one of the group's footsoldiers, along with Belmas..$^{250}$

\section{Douglas Stewart}

Of the five members of Direct Action, Stewart is the least described. He has had little contact with the media. Age 26 when arrested, he grew up in White Rock, BC, just outside of Vancouver, and his parents, who are divorced, were teachers. ${ }^{251}$ Stewart studied math and science at the University of British Columbia, and was very active in the anti-nuclear and environmental movements in Vancouver, organizing the city's first anti-nuclear rally.252

Hansen describes Stewart as somewhat unconventional, a man "not preoccupied with social conventions" who lives his life to a strict timetable and subsists on a diet of brown rice and boiled vegetables with soy sauce. ${ }^{253} \mathrm{He}$ is reportedly extremely knowledgeable about various environmental issues, especially the proposed BC Hydro megaprojects. When Hansen first meets Stewart, he is sharing a house with Taylor, one whose walls are covered in newspaper clippings, many of which feature Stewart at a rally or protest. ${ }^{254}$ It is Stewart who suggests the group target the Amax mining corporation. ${ }^{255}$

\footnotetext{
${ }^{250}$ R. v. Belmas (1986) para 44(d).

${ }^{251}$ Mulgrew, "Thud."

${ }^{252}$ Hansen p. 35; this is debatable, as multiple sources confirm the city's first anti-nuclear rally taking place by 1960. Hansen and Stewart are probably referring to the April 26, 1980

"International Day of Nuclear Protest" held in the city.

253 Ibid., 34 .

254 Ibid., 30.

255 Ibid., 29.
} 
While much less of Hansen's memoir is devoted to descriptions of Stewart's revolutionary ambitions than hers and Taylor's, it is clear that militant action is his aim: it is he who researches and proposes stealing dynamite, he who suggests targeting the transmission line. He also expresses a distaste for the milder, more social political actions that the other DA members and their friends engage in: "I'm not really interested in these low-level actions, or putting out militant rags[pamphlets]. Count me in when you're ready to get some dynamite, guns, money or real action.” ${ }_{256}$ Interestingly, his writings (albeit after the fact) contain none of the "revolutionary analysis" that fellow members Hansen's and Taylor's do.

${ }^{256}$ Hansen, 63. 


\section{Chapter 6: Results}

\section{Summary}

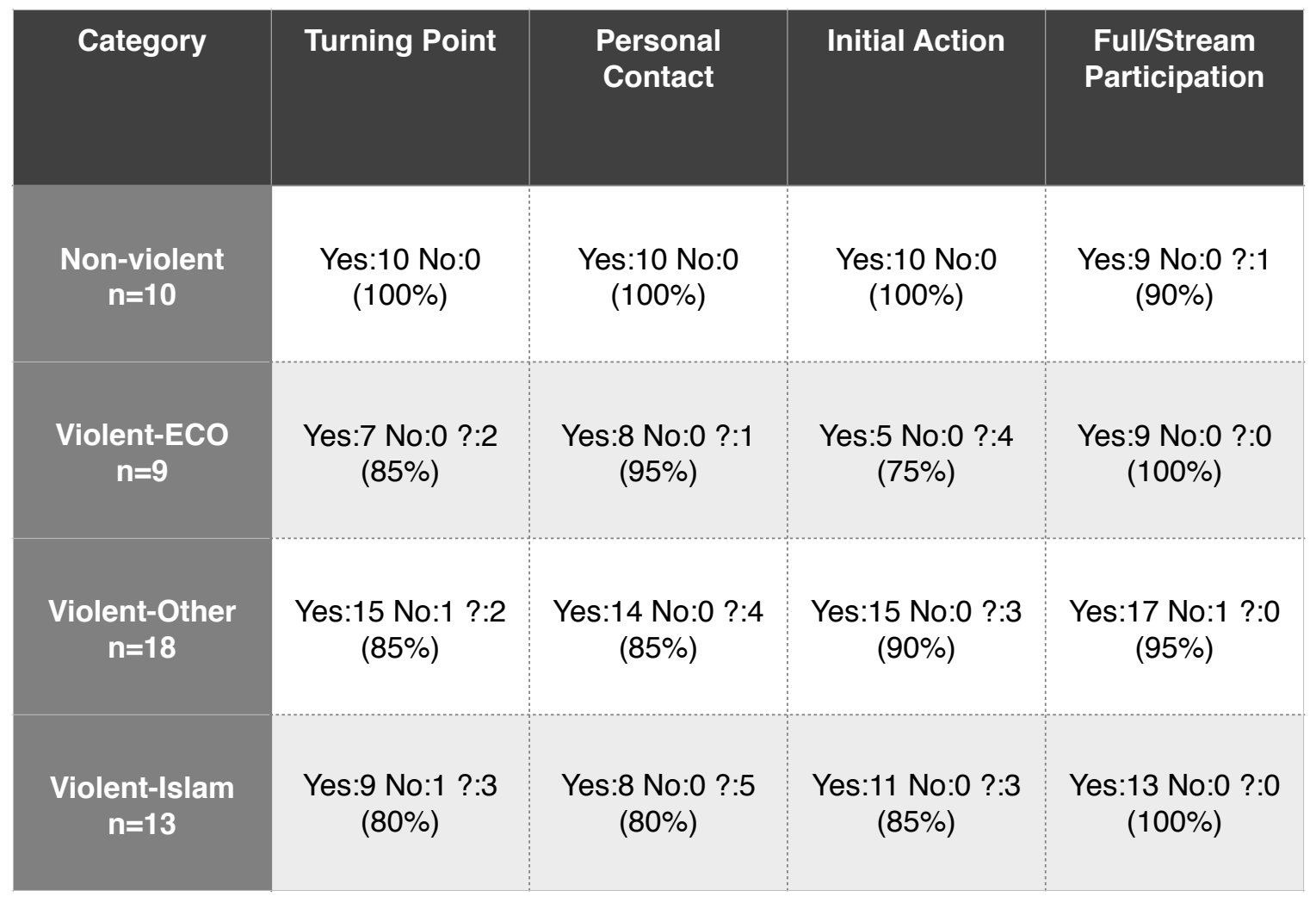

n.b. Percentages are calculated assuming that $50 \%$ of "unknown" data points (? on the chart) are disconfirming. Percentages rounded to nearest $5 \%$.

\section{Hypotheses}

H1: Munson's process of activist mobilisation will hold true for non-violent activism unrelated to abortion.

Confirmed. Munson's process of mobilisation was evident in $>75 \%$ of the non-violent activists subjects' histories, allowing us to reject the null hypothesis.

H2: Munson's mobilisation process will hold true for terroristic mobilisation.

Confirmed. Munson's process of mobilisation was evident in $>75 \%$ of the violent subjects' histories, allowing us to reject the null hypothesis. 


\section{Information not accounted for by Munson's theory}

While there was sufficient evidence within the data analysed to support the utility of Munson's theory of mobilisation, there was also present in some case histories two other factors which could be affecting the accuracy of the data: the possible influence of ideology on one's propensity towards terroristic violence, and the possibility that the non-violent activists interviewed had simply not come into contact with violence-embracing activists, thus weakening the predictive power of Munson's theory.

\section{Ideology}

While not falling neatly into the category of either ideology or worldview, it is clear from the research findings that there is significant attitudinal variation both between non-violent and violent case subjects, and among the subjects themselves, too. For instance, Peter spoke very gently of those who used violence, indicating through his speech and in printed material he later sent as follow-up that he views violence as stemming from a person's own fear and selfhatred. Nuclear weapons, and government expenditure on their purchase and upkeep, represent to him wasted opportunities for doing good in the world, as well as the pinnacle of unspiritual, inhumane technocratic violence. In spite of his many protests on military property, he spoke of service people with respect, noting his work with a veterans' peace group. Contrast this with some of the sentiments expressed by DA members, for whom "much of humanity, most men, and all imperialist economic, scientific, political and military leaders are imbued 
with many of these life-smothering characteristics," which Taylor defined as "invulnerability, hierarchialism, tech-no-rationality [sic], anthropocentricity, womnyn-hating”" 257 Hansen's memoir fairly drips with similar disdain for her fellow man-those who earn a salary, pay for goods instead of stealing them, wear 'normal' clothes, marry and start a family; almost anyone, in fact, who is not committed to an underground guerrilla lifestyle in the pursuit of ameliorative revolution. While the activism of the non-violent subjects interviewed seem rooted in a deep concern for their common man, and often specific examples of mankind-the poor, or the potential victims of nuclear war-the members of Direct Action seem at times to loathe the inhabitants of the world they are willing to use dynamite to defend.

Orsini's research into the genesis of the Red Brigades' lethality suggest to him that revolutionary ideologies like Marxism and anarchism encourage a kind of "the elect vs. the sheeple" mindset which facilitates the dehumanizing of political and ideological opponents and, ultimately, their killing; A similar process seems to have been working on at least some of the DA members. As several studies have shown, ${ }^{258}$ ideology is relevant to violent or protest mobilisation in a group context, and further study with regards to the non-

\footnotetext{
257 Taylor, "Statement of Resistance."

${ }^{25} 8$ Edward Muller and Kenneth Godwin, "Democratic and Aggressive Political Participation: Estimation of a Nonrecursive Model," Political Behavior 6, no. 2 (1984): 129-46; William Rosenau,"'Our Backs Are Against the Wall': The Black Liberation Army and Domestic Terrorism in 1970s America," Studies in Conflict \& Terrorism 36, no. 2 (2013): 176-92; Eitan Alimi,"Relational Dynamics in Factional Adoption of Terrorist Tactics: A Comparative Perspective," Theoretical Sociology 40 (2011): 95-118; Sophia Moskalenko,"Civilians into Warriors: Mechanisms of Mobilization in US Army Recruitment and Training," Dynamics of Asymmetric Conflict 3, no. 3 (2010): 248-68.
} 
mobilised members of DA's peer networks would be needed in order to exclude ideology as a contributing factor to the group's terroristic actions.

Several of the other violent cases showed the importance of ideology (or political affiliation,) especially in the ethno-nationalist conflicts ${ }^{259}$. In these, some subjects spoke of being steeped in their families' and communities' political mythology, mythologies which often glorified violent struggle while demonizing the 'opponent.' Others, however, stressed that they had joined terrorists groups against their parents' explicit wishes, suggesting that exposure to violent ideology is not a straightforward causative variable in violent mobilisation.

\section{Lack of violent contact}

While Munson's theory offers an explanation of why it is unlikely that already-mobilised non-violent activists will become violent, it would allow for a stronger conclusion to be drawn had their been sufficient evidence of contact with violent activists, in order to test their commitment to non-violence. While non-violent activists were asked whether they had been in contact with violenceembracing activists, the replies were mixed. Martha indicated that she had not had such encounters around the specific issue of Litton Industries, in part because such people were unlikely to stay in her group. Patricia reported extensive contact with violent individuals while in prison for her protest activities, but, like Martha, reportedly had little, or no, contact with violenceembracing activists due to her positioning within the non-violent direct action

259 Tabulated under "Violent-Other" on page 82. 
community. Munson would expect these contacts, should they occur to have little impact regardless, and testing this part of this theory would have been beneficial.

The reverse pattern of this contact is also problematic: contact first with European guerrilla supporters, and then with Brent Taylor, seems to have sparked Hansen's mobilisation into violence, and yet many other of his friends who were equally active in social movements remained unmobilised by Taylor's presence. We don't know at what point in their lives this initial contact with Taylor occurred, and so cannot test the turning point-initial contact dyad's importance fully. According to Hansen, the group extended an invitation to participate in some of their less-violent actions to a number of activists; it seems likely that at least a few of whom accepted the invitation discussed further militancy with Taylor or Hansen, so why did they choose not to participate further? As tempting as it is to ascribe DA's creation to the close bonds of friendship and romantic love between its members, Taylor, Stewart and Hansen's long-time romantic partners, who were also active in protest politics, were not mobilised into terroristic violence by similar bonds. 


\section{Chapter 7: Qualitative Results and Discussion}

\section{Non-violent cases}

The ten non-violent activists interviewed ${ }^{260}$ ranged in age from $80-23$, and were engaged with anti-nuclear activism specifically and environmental activism more generally. Activists from many tactical 'streams' were selected, from awareness-raising and advocacy work, to legislative consultation to non-violent direct action and criminal trespass. In common with their violent counterparts in Direct Action, most of the activists interviewed had been mobilised around other issues prior to their becoming more focussed on one issue in particular. All the activists interviewed were Canadian or American citizens, and all spoke English as their primary language. All of the activists had attended post-secondary education, although not all had completed four-year degrees.

Most of the interviews lasted well over one hour each, allowing for wideranging discussions prompted by the semi-structured questionnaire. The activists were generally quite eager to speak about their developing politics beliefs and activism histories, although some expressed skepticism as to the study's focus on biographical history and actions, versus the beliefs side of mobilisation. It is impossible to transcribe the full interviews here, due to the focus (and space) limitations of this paper. Neither could a composite 'representative activist' be drawn, as the life histories of the activists interviewed varied dramatically. Instead, examples of concordance with, and deviation from,

${ }^{260}$ See Appendix 2 for a list of interviewees. 
Munson's theory of mobilisation have been taken from each of the interview, in order to better illustrate the empirical findings qualitatively.

\section{Turning Point}

Munson only recognized the importance of a turning point in the history of the people he interviewed after his research was completed, and as such, did not specifically seek such information from his subjects. ${ }^{261}$ In order to ascertain whether the turning point held true for the activists interviewed in this study, a broad life history was taken, with detailed follow-up questions asked when a respondent identified periods of mobilisation. Often the link between a 'turning point' and an individual's subsequent mobilisation weren't identified by the activist themselves, and in some cases were discounted by them as unimportant or misleading when discussed. ${ }^{262}$ Nevertheless, every activist interviewed became mobilised following a period of change in their life which corresponded with the criteria laid out by Munson in his 'turning point.'

Some activists, like "Patricia" underwent multiple turning pointmobilisation pairings: her initial mobilisation into non-violent direct action came about after returning to the United States from two years spent in Ethiopia with the Peace Corps, and her mobilisation into high-risk anti-nuclear activism specifically followed a move from the East Coast to California, and was concurrent with a conversion to Roman Catholicism. "Zaphod" reported several

\footnotetext{
${ }^{261}$ Munson, 57.

${ }^{262}$ In order to guard against this kind of self-editing, I deliberately kept my discussion of the aims of my research very vague, without mention of testing Munson's theory until after the interviews were complete.
} 
turning point mobilisations, as well: initially, he became aware of and engaged with climate issues while attending university; several years later, and after moving inter-provincially, began working with a group promoting environmental awareness. "Alyssa" became mobilised generally while away from home at university,initially into student and feminist issues. Her specific mobilisation into environmental activism occurred after beginning a new job. "Martha" became mobilised into political activism generally after starting university, and into anti-nuclear activism more specifically following the birth of a child and a religious conversion.

Physically and spiritually leaving the Jesuit priesthood was the turning point for "Peter," who became mobilised into non-violent direct action in support of peace and against nuclear weapons, while "Rupert" became mobilised after a year spent on travelling with Katimavik, a Canadian youth service organization. "Janet" mobilised into activism after moving in with a romantic partner, and "Eric" began his activist career following a summer internship in another province while at university. "Suzanne" also became mobilised after moving to another, larger, city for university. ${ }^{263}$

\section{Initial Contact}

More than any other step in Munson's theory, the non-violent activists interviewed resisted the importance of a personal contact who introduced them

\footnotetext{
${ }^{263}$ Becoming mobilised after having moved for post-secondary education was a common theme, and it would be interesting to investigate the difference in mobilisation rates between students who live at home while attending university or college, and those who move away. The image of angry, protest-happy students has generally been discussed as being a result of a cognitive opening, or broadening of the mind, when it in fact might be more a function of a life transition/ turning point scenario.
} 
to a movement. In interviewing the older activists, some of whom had been engaged with social justice issue for more than fifty years, it became clear that for their general activist mobilisation, a personal contact was difficult to identify.

For instance, Peter described his anti-poverty and peace activism following his leaving the priesthood as happening within a larger social network, but when he talked of his mobilisation into Ploughshares-type anti-nuclear direct actions, it became clear that his future wife had played an influential role in introducing him to the movement. Martha described her general political activist mobilisation as being self-directed: inspired by left-wing political victories in other provinces, she sought out a political party, attended meetings and rallies alone, etc. However, she freely describes a close friend and admired mentor who introduced her to the anti-nuclear group she would spend several years immersed within, citing a vague awareness of the issue before his personal invitation sparked her joining.

Zaphod's specific activism within the group he is currently engaged with came about through the personal contacts he developed through a job within the organization unrelated to activism, as did Alyssa's; neither was mobilised around the issues beforehand, although both had histories of general activism. Rupert's mobilisation began after contact with a gay rights activist whose lived experience inspired Rupert into action, although he mobilised around very different issues. Janet's boyfriend was her personal introduction to environmental activism; interestingly, she persevered with it long after her boyfriend had left the movement (and the relationship.) Eric initially attended a rally with a group of 
friends who had seen poster about it, although he recalls being the only one of the group who subsequently pursued activism around the issue. He did not identify any one person as being involved in his mobilisation. Suzanne recalled discussing nuclear war with her university classmates, one of whom knew though through her church youth group someone who was involved in the peace movement. Although not religious herself, this person was Suzanne's eventual introduction to protest.

\section{Initial Action, Full Participation and Activism 'Streams'}

The initial actions of the non-violent activists interviewed were as diverse as the interviewees themselves, such as: attending a lecture to learn more about acid rain, protesting apartheid, participating in a student sit-in, organizing a conference, picketing a business that supplied the war effort. In all cases, the time lag between the initial movement contact and the first participatory action was very small. The relationship between those initial actions and the subsequent pattern of activism was not always straightforward, as most of the activists interviewed had become mobilised multiple times, around multiple issues. However, a pattern of action emerged from most of the interviews, in which the subject's initial actions were indicative of the activism "stream" in which they would continue to engage.

Peter's first forays into social justice activism were direct actions (sit-ins, etc.) in support of poverty reduction. Through this network of activists he met people in the anti-nuclear movement, with whom he was soon engaging in dramatic larger-scale blockades and trespasses on military bases. He continued 
in the stream of non-violent direct action through his work in Christian Peacemaker Teams as well as his work as a non-violence trainer. Patricia's activism evinces a similar pattern: drawn to an 'in your face' style of student protest for her initial action, she embarked on a life-long path of medium- to high-risk direct actions including large demonstrations and symbolic trespasses on military property. Patricia felt very strongly when interviewed that 'action'purposeful, intensive and dramatic demonstrations of passion and intent-were necessary to create change, and while she also diligently wrote letters to her legislators, she was almost dismissive of their potential impact. Suzanne's actions against nuclear weapons began as they have continued for several decades: with rallies and demonstrations aimed at raising awareness of the issue and pressuring industry participants to cease.

Zaphod's history is shows a similar pattern, but in a different stream. His initial actions were information-seeking, attending lectures and doing research around acid rain and, later, climate change. He describes his activism as grounded in his love for science and knowledge, and feels very strongly that raising awareness of the science behind climate change and other environmental issues is key to promoting change. While he also participates in demonstrations, his main activism manifests in outreach and education work, and his choice of activism group reflects those priorities. He was less sure of the effectiveness of the direct actions or 'stunts' like those pursued by Greenpeace, fearing that the governmental suspicion they engendered would trickle down to groups such as his. 
Of the activists interviewed, only one had definitively changed 'streams' of activism. Rupert's environmental activism was initially focussed on Greenpeace, and he participated in their 'guerrilla'-style public events for several years, until he began working within an international rules-based NGO network within which he cannot engage in illegal protests, or risk losing his accreditation. He described his personal skills and interest as being a better 'fit' for the group he was working with currently, but was very clear that he supported more direct tactics and felt they played an important role in furthering environmentalism. He was also the only activist interviewed who was willing to admit to supporting the idea of 'ecotage' or property destruction such as that practised by the ELF.

Research into the attitudes towards more-violent protest held by volunteer or part-time activists versus those who, like Rupert and Zaphod, are currently employed by activist organizations, might be useful, in order to determine the effect of employment-related biographical availability on tactical choices. Like Rupert, Patricia was also conscious of the effects of availability-in her case, being the parent of young children-on her choice of protest tactic. Rupert's protest practice has been moderated by his position in an NGO, while prior to this his protest was unrelated to his employment. Janet works closely with government, advising on environmental issues, which she sees as the most effective way of addressing larger regulatory problems that cause environmental degradation, for instance; she did not explicitly say whether her job influenced her decision not to take part in more risky protest, but she did state that she 
believed 'Black Bloc' tactics or Greenpeace-style stunts were ultimately ineffective.

\section{Beliefs About Tactics}

Not surprisingly, all of the activists interviewed had beliefs-about the issue in question, and about the effectiveness of various protest tactics-which aligned closely with the groups or organizations they were a part of. The Christian antinuclear activists in particular had very well-articulated beliefs about the practice and morality of non-violent protest, starkly juxtaposed against what they saw as the inherent violence of nuclear weapons. To oppose the indiscriminate violence against humans caused by a nuclear bomb with their own indiscriminate bombing, as did Direct Action, was anathema to the activists interviewed. Patricia, who came of age as an activist in the turbulent and often violent 1960 , was candid in admitting that she shared the revolutionary aims of groups like Weather Underground and RAF's, but disagreed strongly with their tactics: violence against people is wrong, she stressed, even if they are, like military personal or prison guards, complicit in greater violence. (Whether she would have been as unequivocal if interviewed before she had adopted her nowlongstanding practice of non-violence is unclear.) Martha, who was heavily involved in the non-violent opposition to Litton Industries and the cruise missile, was as disgusted by DA's actions when interviewed thirty years later as she had been in 1983, when her group led the condemnation of the bombing. By the time of the bombing Martha had already developed a faith-inspired practice of interventionary non-violence, which involved a respect for the lives of all persons, 
including the Litton employees-something that could not be set aside without compromising her (and her group's) moral opposition to nuclear warfare. Even when discussing the potential effectiveness of the bomb-Litton divested itself of cruise missile componentry fairly soon afterwards-Martha was adamant in her opposition to such violence. Suzanne was similarly opposed to violence in all its forms, goings far as to adopt a largely vegan and cruelty-free lifestyle. Like the other anti-nuclear activists interviewed, Suzanne drew a direct parallel between what she perceived as the inhumane violence of nuclear war and her commitment to non-violence.

Zaphod, Alyssa and Eric work with the same environment activist organization, one whose charitable status in Canada hinders their choice of tactics quite explicitly. ${ }^{264}$ Instead of the more dramatic protests favoured by, say, Greenpeace, the group focusses on education, outreach and consciousnessraising, providing organization and policy direction around a broad range of environmental issues. All three of them identified a lack of education and awareness as being an important factor in environmental degradation, and described themselves and their activism as being in support of an educational mandate. When asked about the impact of the group's tactical restrictions on his own activism, Zaphod indicated that while he might attend protests on his own time as an individual, he agreed with the overall direction the group took; the

\footnotetext{
${ }^{264}$ Environmental charities in Canada have been recently targeted by the government with extensive audits, which some believe are linked to their opposition to government-favoured resource development projects: http://www.cbc.ca/news/politics/7-environmental-charitiesface-canada-revenue-agency-audits-1.2526330. Recent government statements have not clarified the issue: http://www.theglobeandmail.com/news/politics/cra-audits-charitable-status-of-tidescanada-amid-tory-attack/article4105719/
} 
group's tactics aligned with his own beliefs. Alyssa was not active with environmental issues before coming into contact with the group; her beliefs and activism, as described during the interview, were a product of her time with the group, and she saw them as dovetailing with her own beliefs and skills. All three had come into contact with activists from other environmental groups mobilised around the same issue, but none had been interested in changing teams, so to speak: Alyssa volunteered that she was unimpressed with the other groups' focus, while Zaphod expressed discomfort with their tactical choices. Eric cited his relationships with the people involved in his organization as the main reason he continued to belong, although he did respect the work of other environmental groups.

\section{Beliefs About Violence}

The ten subjects whose interviews have been analysed in this paper ${ }^{265}$ are, by definition, non-violent: that is to say, their activism and protest has been of a sort that did not intentionally risk or cause harm to persons. This non-violence was ascertained by the researcher prior to their being included in the interview pool, as well as being further teased out during the interviews. Subjects were asked about their attitudes towards more violent forms of protest, primarily pragmatically-as in,did they think it was effective, although some respondents gave more philosophical or moral critiques. Some ${ }^{266}$ were asked their opinions

\footnotetext{
265 Three more activists were interviewed, but they did not consent to having their information included as part of this paper.

${ }^{266}$ In fact all were asked, but only a few were familiar with the group and its actions-a function of the interviewees age, nationality and residence.
} 
about Direct Action's violence specifically, or about the actions of the ALF and ELF. To a person, every subject rejected actions which caused harm to humans, such as the Litton bombing, and disparaged anyone who would commit this kind of act. There was less vehement condemnation of actions causing only property damage, however, even if these had the potential to cause harm to humans accidentally, as in the many ELF and ALF arsons. Everyone interviewed except Rupert disavowed large-scale illegal (but non-violent) 'protest theatre' events as being ineffective and counter-productive; however, none condemned their participants as wrong-headed or immoral, but rather ill-informed. Very few subjects reported any kind of contact with violence-embracing activists, and most suggested that their own activist groups would be the wrong 'fit' for such people.

\section{Conclusion}

The ten non-violent activists analysed support the applicability of Munson's theory of mobilisation beyond anti-abortion activism and into activism more generally. The 'turning point' and 'initial contact' steps, in particular, were notable as being present, and easily found, in the life histories of those interviewed. With the exception of Rupert, who crossed streams when his change in career necessitated it, all of the activists followed a tactical (and philosophical) path set in motion with their initial forays into activism. Every activist showed a remarkable degree of coherence between their beliefs about an issue and their beliefs about the actions they took in support of that issue; their tactical choices were intentional and congruent with their beliefs, not merely actions that were convenient or popular. In sum, Munson's theory of mobilisation shows great 
promise of explaining more fully differential recruitment into activism, both violent and non-violent, and warrants a fuller empirical test using a larger number of subjects. ${ }^{267}$

\section{Violent Subjects}

Using already-conducted research, the case histories of persons who were either self- or researcher-identified as using and condoning terroristic violence ${ }^{268}$ in support of socio-political aims were analysed for details that would allow for the testing of Munson's theory; thirty-seven sufficiently-detailed biographies were identified.

\section{Turning Point}

As with the non-violent activists, the 'turning point' was present in all but three of the case histories analysed. ${ }^{269}$ For many of these, a physical relocation, whether voluntary or forced, preceded mobilisation. ${ }^{270}$ For example, Vidino's ${ }^{271}$ study of mobilisation in a small Jemaa Islamiyaa-linked cell recounts how four young Tunisians became involved in extremism after moving to Italy, while in an

\footnotetext{
${ }^{267}$ Further testing might more usefully be limited to one specific issue, so that the beliefs of the subjects could be explored in greater depth, as Munson did with his original research into pro-life campaigners.

${ }^{268}$ With the exception of those who used terroristic violence to further environmental and animal rights agenda, whose attacks were aimed purely at property, the violent subjects meet most definitions of "terrorist" or persons engaged in "terrorism," including the targeting of humans.

269 Three cases did not have sufficient information to test the step.

${ }^{270}$ Although not included in the data set, Post's biographical sketch of IRA hunger striker Bobby Sands includes disjoining the IRA after being intimidated from his job; his family had been forcibly reacted several times in the preceding few years, as well.

${ }^{271}$ Lorenzo Vidino, “The Buccinasco Pentiti: A Unique Case Study of Radicalization," Terrorism and Political Violence 23, no.3 (2011): 398-418.
} 
interview with Horgan, ${ }^{272}$ a Norwegian far-right extremist described his mobilisation into violence as coming about after a move to Oslo from his rural hometown.

Similarly, a Dutch militant mobilised after leaving his parents' home and getting his own apartment: "The move confirmed [his] passage from radicalisation to militancy." ${ }^{273}$ Divorce featured in the narratives of several violent extremists ${ }^{274}$, as did the beginning and ending of romantic relationships in general. ${ }^{275} \mathrm{~A}$ bereavement in the immediate family, ${ }^{276}$ especially when such a death provoked a change in living circumstance was also reported multiple times, as was a parent being imprisoned or released from prison. Educational transitions, especially leaving school and/or commencing university, were also very common across the spectrum of violent political mobilisation ${ }^{277}$, as was a change in employment status. ${ }^{278}$

Violent subjects who, like some non-violent ones, underwent multiple mobilisations (from non-activist to activist to violent activist, for example)

\footnotetext{
${ }^{272}$ Horgan, “Walking Away.”

${ }^{273}$ Lorenzo Vidino, “The Hofstad Group: The New Face of terrorist Networks in Europe," Studies in Conflict and Terrorism 30(2007):582. Vidino's account of this terrorist cell is in fact replete with references to the participants' turning points, among them a marriage, an international move, a stint fighting abroad, and an enrolment in college.

${ }^{274}$ For example, in the British-Australian convert to Islam Jack Roche; in Anne Ally and JasonLeigh Striegher, "Examining the Role of Religion in Radicalization to Violent Islamist Extremism," Studies in Conflict and Terrorism 35, no.12 (2012): 849-862.

275 For example: Berko and Erez, "Gender," 354.

${ }^{276}$ For example: Olsen, “Militant Radicalization," 17.

277 For example: Margherita Cagol, the mother of the Red Brigades, who radicalised while at university. In Alessandro Orsini, "Poverty, Ideology and Terrorism: The STAM Bond," Studies in Conflict and Terrorism 35, no.4 (2012): 665-692.

${ }^{278}$ For example: Basque separatists, in Post, “The Mind," 59.
} 
mobilised into violence after turning points, as in the case of Daniel McGowan, convicted of environmentally-related violence in the US: his activism began encompassing violence after a move to the West Coast. ${ }^{279}$ Omar Rezak, a Palestinian militant, also displays multiple mobilisations: he began training with a PLO-linked youth camp as a child after the 1968 forced a relocation to a refugee camp. His full mobilisation into political violence came years later, when, after going AWOL from his mandatory military service in Jordan, he joined first Fatah, and later, the Abu Nidal Organization. ${ }^{280}$

These turning points are identifiable even when, as was generally the case, the cited researchers were focussing on different aspects of violent mobilisationpsychological feelings of grievance or isolation, for instance, or ideological motivations. ${ }^{281}$ For instance, Post's sketch of Gudrun Ensselin, a member of the Baader-Meinhoff cell of the RAF, focusses on her reaction to the 1967 murder by police of Benno Ohnesorg-identified by many as the catalysts for the group's founding-and yet also presents as innocuous detail the fact that 1967 was also the year in which she gave birth to a child and met Andreas Baader, for whom she left her family less than a year later. ${ }^{282}$

\footnotetext{
279 Marshall Curry (filmmaker), If a Tree Falls: A Story of the Earth Liberation Front, 2011; http://www.ifatreefallsfilm.com

${ }^{280}$ Post, "The Mind," 18. Rezak apparently sought the most violent extremist groups, rejecting others along the way as too mild to be effective. This may give credence to the idea that truly violent individuals are unlikely to remain in non-violent protest groups, as as suggested in several of the interviews with non-violent activists conducted for this study.

${ }^{281}$ For example: Elena Mastors and Rhea Siers, "Omar al-Hammami: A Case Study in Radicalization," Behavioral Sciences and the Law 32 (2014): 377-388.

282 Post, “The Mind,” 125. Ulrike Meinhoff left her husband in 1967, also to join in with Baader.
} 


\section{Initial Contact}

Initial contact with a violence-embracing movement was more difficult to identify in the extant studies, with nine lacking sufficient information; even so, there were no cases in which a personal contact was specifically contraindicated. Instead we see a near-litany of social network linkages: "I was invited;" 283 " There was this guy I was seeing. He joined and I did, too;"284 "Someone asked me if I wanted to join in;"285 “[I] was approached;”286 “Let’s just say I was introduced to a couple of people.”287 Friends, lovers, colleagues, university professors, cousins -all of these were identified as movement contacts in the surveyed research.

It is important to note that violent subjects from places where terrorism or violence has broader populational support, such as in the Northern Irish or Palestinian conflicts, reported an abundance of personal contacts with violent groups, reducing the CT utility of the step on its own, independent of the turning point. A Hamas member makes it clear when he describes joining as "the normal thing to do, as all the young people were enlisting." ${ }^{288}$ He was personally recruited by a friend, but it is difficult to determine if this personal contact was in fact necessary to his recruitment, given the visibility and ubiquity of Hamas within his community. 'Alan,' an Ulster Volunteer Force member, describes his

\footnotetext{
283 Olsen, "Roads to Radicalization,” 28.

284 Post, "The Mind," 58.

285 Olsen "Militant radicalization," 29.

${ }^{286}$ Horgan, "Walking Away," 54.

${ }^{287}$ Ibid. 65 .

288 Post, “The Mind,” 186.
} 
familiarity with the semi-clandestine group: "Well, you know, with growing up in a [contested] area, you fairly well know who the players were ... I probably socialized with some of them, and so it was just a matter of ... making them aware you were interested." ${ }^{289}$ IRA member 'Michael' described his community as being encouraging of his efforts to join first Sinn Fein and then the IRA; he was born in the Republic of Ireland "into a family background that supported Irish militancy in the early twentieth century phase of the IRA's development,"290 and surrounded by friends who aspired to join. These cases illustrate why the opportunity to join or be recruited is insufficiently predictive of mobilisation, absent another factor such as Munson's turning point.

\section{Initial Action/Full Participation/Stream}

Initial actions upon coming into contact with, or joining, a violent group, were often clearly criminal or violent, but at a lower level of intensity: actions in support of an attack, for example. As has been discussed in the literature the clandestine nature of terrorism seems to provoke a probationary period for new recruits, in which they are tested for 'nerve' and trustworthiness. "Michael" describes his first IRA meeting:

"It was in like a drying shed, where barley would be dried and stuff like that. So you pull all the barley back with theses wooden shovels and there are these

\footnotetext{
${ }^{289}$ Horgan, "Walking Away," 53.

${ }^{290}$ Ibid. 78.
} 
guns. So the guns have to be cleaned and the guns are going to Northern Ireland. So that's my first meeting." 291

The Red Brigades reportedly had their new recruits "carry out an action of proletarian expropriation, signifying rejection of a consolidated political logic;"292 in other words, shoplift. "Giorgio" in his Memoirs of an Italian Terrorist describes it thusly: "This first action was an important step. For the first time I was committing an illegal action outside of the context of a mass demonstration. And the same thing was true of most of the comrades who took part in [the theft of jeans from a boutique.]"293 Criminal activity in support of terrorism was a commonly-reported initial action. ${ }^{294}$ Direct Action's probationary members were initially taken along on vandalism/sabotage actions, and to a makeshift shooting range ${ }^{295}$; paramilitary training featured in several terrorist narratives ${ }^{296}$, and the excitement provided by this clearly contributes to what Sageman and others have identified as the "fun-seeking" element of terrorist mobilisation"297: "[I] wanted 'to get out of the house' so [I] decided to pursue military training.”298

\footnotetext{
${ }^{291}$ Ibid. 84.

${ }^{292}$ Grandi, L'ultimo brigatista, in Orsini, “Red brigades," 88.

293 Giorgio, 67.

${ }^{294}$ For example, Horgan, “Walking Away;” Vidino, "Pentiti;” White, "Micromobilization;” Post "Mind of the Terrorist."

295 Hansen, 124.

${ }^{296}$ For example, Anne Aly and Jason-Leigh Streigher, "Examining the Role of Religion in Radicalization to Violent Islamist Extremism," Studies in Conflict \& Terrorism 35, no. 12 (2012): 849-62; Berko and Erez, "Gender;" Magourik,"Connecting."

${ }^{297}$ Sageman, “Understanding Terror;”; Cottee and Hayward, “Terrorist Emotives;” Blazak,” White Boys."

${ }^{298}$ Berko and Erez, “Gender,”674.
} 


\section{Chapter 8: Recommendations and Conclusions}

\section{Further research}

The results of this plausibility probe of Munson's theory suggest that it is very relevant to the understanding and deterrent of terrorist mobilisation, especially with regards to single-issue extremism. Munson's theory of mobilisation has been found to be applicable to both non-violent activist mobilisation as well as terrorism, suggesting that further testing using interview data designed specifically for such research is warranted. It is recommended that further testing of Munson's theory be undertaken, which could be done at a moderate cost and in a short time frame by using non-public source material such as criminal records, address histories etc. Looking at the life histories of 'homegrown' terrorists, especially native-born citizen converts, could be very effective, given that our current understanding of violent Islamist radicalisation assumes that religious ideology plays a significant motivating role in the process. If research reveals that the 'beliefs' of radical converts are a function of their actions, rather than the reverse, it offers an opportunity for a more accurate analysis of exactly where the mobilising individual comes into contact with violence. ${ }^{299}$ There are sufficient examples of persons convicted of terroristic offences to test the theory's explanatory power more fully.

\footnotetext{
299 See Jamie Bartlett and Carl Miller, "The Edge of Violence: Towards Telling the Difference Between Violent and Non-Violent Radicalization," Terrorism and Political Violence 24:1 (2012) pp.1-21, for a discussion of the non-utility of "radical religious beliefs" as a predictor of violent mobilisation.
} 


\section{More effective use of counterterrorism resources}

Munson shows that it is highly unlikely that already-engaged activists with a history of non-violent protest will suddenly choose to use violence in support of an issue. Perhaps holding true more for activist groups as a whole than individual activists per se, the 'action before beliefs' paradigm suggests that members of a non-violent group have that non-violence as a part of their beliefs about an issue, not just as a practice.

Martha's description of her group's reaction to the Litton bombings makes this clear: that violent bombing, she said, was anathema to her group, as it violated one of their core principles-that the use of indiscriminate, dangerous weapons was inherently wrong. Just as, in the group's opinion, the horrific civilian casualties of nuclear weapons made their use indefensible even by democratic nations or to shorten a war, the good intentions of DA did nothing to mitigate the harm caused to the Litton workers and police officers in the bombing. People for whom terroristic violence was a feasible protest tactic “wouldn't have been interested in our group," she says, because of their focus on information campaigns, protests and non-violent civil disobedience. Anyone harbouring the desire to 'refuse the cruise' with dynamite, had they happened upon Martha's group, would either have quickly left, or been brought round to a non-violent way of thinking. ${ }^{300}$

\footnotetext{
${ }^{300}$ It is difficult to make specific reference to the various peaceful, but illegal, activities of Martha's group without jeopardizing the group's and her, anonymity; suffice to say that they were engaged in non-violent campaign to have Litton refocus on peaceful technology before, and after, the DA planted a bomb.
} 
In 2002, testifying before the US House of Commons committee, then- FBI domestic terrorism chief James Jarboe (perhaps inadvertently) made this distinction quite clear, when he described the ELF as being founded by activists frustrated by their peaceful 'parent' groups' stances against violence: Greenpeace and Earth First! both supported non-violent direct action and civil disobedience, but rejected actions such as tree spiking that might harm people. ${ }^{301}$ To do violence, the eventual founders of the ELF first had to leave their non-violent groups.

Munson's idea of 'streams' of activism is supported by terrorism research showing that the in-group socialization processes within underground or clandestine groups-wherein "you c[an] only exchange ideas with other [people] who thought like you; there wasn't anybody else to talk to"302_-produce the actions and the beliefs of its members. Dissent is rarely tolerated, such that the disenchanted must leave to form their own groups (splintering) or disengage completely. ${ }^{303}$ Group members' thinking around an issue coalesces after prolonged exposure to their own exclusive feedback. An investigation into differing motives for armed group mobilisation in Nigeria, ${ }^{304}$ for example, concluded that while many members had pragmatic reasons for joining-gains of power and money, protection-continued belonging to the group produced a less

\footnotetext{
${ }^{301} \mathrm{http}: / /$ www.fbi.gov/news/testimony/the-threat-of-eco-terrorism

${ }^{302}$ Mauricio Florez-Morris, "Why Some Colombian Guerrilla Members Stayed in the Movement Until Demobilization," Terrorism and Political Violence 22:2 (2010) p. 222

${ }^{303}$ See Hogan (2009) for a deeper discussion of terrorist disengagement.

${ }^{304}$ Robert Barrett, "Interviews with Killers: Six Types of Combatants and Their Motivations for Joining Deadly Groups," Studies in Conflict and Terrorism 34 (2011) pp. 749-764.
} 
rational, more ideological commitment in all adherents over time: actions shaping beliefs.

Munson's 'streams' are already accepted by many CT partitioners; for instance, the UK's 'Prevent' pillar of CT strategy contains this description of how radicalisation to violence occurs within a group:

"Social movement and social network theory emphasize that radicalisation is a social process particularly prevalent in small groups. Radicalisation is about 'who you know'. Group bonding, peer pressure and indoctrination are necessary to encourage the view that violence is a legitimate response to perceived injustice. We have also seen evidence to support this theory from classified Government reporting." 305

This process works the same way to delegitimize violence in mainstream protest groups. If CT practitioners and governments are willing to believe in the 'radicalising' power of in-group dynamics within a terrorism context, it should be easier to believe these same forces produce a resistance to terroristic violence in non-violent protest groups.

This suggests that law enforcement needn't cast as wide a net in surveilling activist groups, if the primary concern is terroristic violence, ${ }^{306}$ nor should they suspect previously-peaceful groups when an attack occurs. Munson makes it clear that rather than the depth of one's beliefs on an issue, one's protest practice is a better predictor of mobilisation into violence. This in turn indicates that extensive surveillance and attempted penetration of non-violent protest groups is wasteful at best, and counterproductive at worst. As detailed in information

\footnotetext{
305 https://www.gov.uk/government/uploads/system/uploads/attachment_data/file/97976/ prevent-strategy-review.pdf

306 Of course, groups with a history of non-violent civil disobedience, or non-terroristic sabotage, present their own law enforcement challenges and by Munson's reasoning are likely to continue doing so.
} 
recently made public, counter-terrorism and national security assets in Canada, the United States and the United Kingdom are currently being used to investigate some groups with a long history of non-violent, if sometimes illegal protests. ${ }^{307}$ In some cases, this has involved national security officials investigating individual activists with no history of violent protest. ${ }^{308}$ Munson's theory would point to a better use of CT dollars currently spent monitoring members of Greenpeace, for instance, a group whose protest practice, and therefore beliefs frame, is extremely unlikely to support terroristic protest violence..$^{309}$

\section{Better relationships with non-violent activists}

In part because of an incomplete understanding of how activist mobilisation works, the relationship between government, industry, law enforcement and social movement activists is often marred by mutual suspicion and discord. A common reasoning seems to be that single-issue terrorists do not 'just happen out of nowhere' but rather emerge from a larger, less militant

\footnotetext{
307 http://www.vancouverobserver.com/politics/harper-governments-extensive-spying-antioilsands-groups-revealed-fois, accessed 21 Nov. 2103.

$308 \mathrm{http}$ //www.washingtonpost.com/national/health-science/as-eco-terrorism-wanesgovernments-still-target-activist-groups-seen-as-threat/2012/02/28 accessed 21 Nov 2013.

309 This Greenpeace Canada blog posts reveals that Greenpeace rejects violent tactics as being ineffective, not merely 'wrong;' note that it is written by someone who has engaged in illegal, but non-violent protest. http://www.greenpeace.org/canada/en/Blog/choosing-a-diversity-ofnonviolent-tactics/blog/12093/
} 
movement. ${ }^{310} \mathrm{CT}$ practitioners who ascribe to this pyramid of beliefs and actions, where the small, sharp point of militancy is supported by a larger core of more peaceful believers are more likely to assume that peaceful groups at the very least have prior knowledge of violent acts, if they are not actively supporting a violent fringe.

This could be seen even in the police reaction to the Cheekeye-Dunsmuir bombing: after months of fruitless interviewing of non-violent activists, the police concluded that the explosion was the work of a "violent underground splinter faction of an environmental group," ${ }^{11}$ assuming that the perpetrators must have been an outgrowth of the larger, peaceful campaign. Using such reasoning, these groups are therefore the legitimate target of suspicion and surveillance, even as the RCMP investigating the bombing "reached the conclusion that it [was] highly unlikely the explosion was engineered by a mainstream environmental group opposed to BC Hydro expansion," ${ }^{12}$ recognizing the pacific nature of most of the opposition protesters.

\footnotetext{
${ }^{310}$ This may be partially true, when it come to the formation of more radical or violent groups, such as the ELF/Earth First! split, but it is much less definitive when it comes to the trajectory of individual TV activists. Take the case of Daniel McGowan, convicted in the US of terroristic arson as a member of an ELF cell: although he was aware of, and partially mobilised around, general environmental issues prior to his joining ELF, it was only after he moved from NY to OR with the intent of becoming part of a militant environmental movement that he started engaging in direct action and civil disobedience. While in OR (turning point) he came into contact with TV activists (contact) and began involved in increasingly serious actions that culminated in several arsons (full participation.) He had not been involved in such activity prior to his becoming mobilised into the ELF, nor had he been a member of a less radical group involved with West Coast environmental issues. See Jessica Lee, "Enemy of the State: The Story of Daniel McGowan," The Indypendent \#109 (15 September 2007.); If a Tree Falls: A Story of the Earth Liberation Front (Film by Marshall Curry, 2011.)

${ }^{311}$ Tafler (1982.)

${ }^{312}$ Ibid.
} 
Munson's framework turns this pyramid on its head, showing that activists belonging to non-violent groups, and those groups themselves, are not all potential extremists, but instead potential allies in the fight against terroristic protest violence. A recognition by law enforcement of the non-violent nature of a group's activism-whether licit or illicit-might bring about cooperation in identifying those activists who meet Munson's criteria for possible violent mobilisation. Established activist groups with a large public presence such as Greenpeace or the Wilderness Committee are best placed to be able to identify individuals who have recently left the group due to dissatisfaction with nonviolence, or who meet Munson's turning point criteria and might therefore be vulnerable to mobilisation into violence. For instance, even within the larger, loose-knit 'anarchist' community in 1980 os Vancouver, it seems like the members of DA might have been guessed at, if not known:

Brent Taylor and Anne Hansen in particular were pretty notorious in Vancouver ... Many activists who didn't even know them suspected that they probably had something to do with Direct Action. They were the only ones who regularly went to demonstrations all masked up, looking much more prepared for protests in Germany than in Vancouver. ${ }^{313}$

Practitioners who espouse the uncoupling of illegality and violence, and recognize the difference between civil disobedience or peaceful direct action which may cause property damage or disruption, but which is not aimed at harming people, and terroristic protest which, at the very least, shows a

313 Jim Campbell, Vancouver Five: Armed Resistance in Canada, Vancouver: Solidarity (2001) p. 9, digitized copy at http://contentdm.library.uvic.ca/cdm/ref/collection/collection8/id/234 
willingness to cause human harm, may find that they can instead rely upon mainstream protest groups as allies in combatting violent extremism.

In addition to using non-violent activist groups as allies against violence, there is growing evidence in the literature that state repression or belittling of non-violent protest can in fact engender radicalisation into violence. The belief in the effectiveness of conventional political participation is strongly protective against more radical participation; in its absence, terrorism flourishes. In his classic economic analysis of differential participation, Muller ${ }^{314}$ found that what he called "aggressive political participation" 315 negatively correlated with respondents' feelings of personal political efficacy; similar to Della Porta's ${ }^{316}$ 'blocked participation' hypothesis, aggressive participation was favoured when people felt unheard. Especially when 'highly psychologically involved' in politics, low-efficacy individuals chose aggressive political participation. ${ }^{317}$ Bosi and Della Porta found ${ }^{318}$ that many make a rational, considered choice of violence, often after becoming discouraged by traditional political participation. In one study, political participation was "the most important factor" in preventing the violent

\footnotetext{
314 Edward Muller, "An Explanatory Model for Differing Types of Political Participation," European Journal of Political Research 10 (1982) pp. 1-16.

315 This model included five behaviours: "seizure of factories, offices and other buildings; refusal to pay rent (equating); participation in fights with lice or other demonstrators; participation in a group that wants to dislodge the government by violent means; participation in a wildcat strike." (p. 8) Given Muller's data source, 1970s West Germany, it seems likely that some terroristic violence is captured in his definition.

${ }^{316}$ Della Porta, "Social movements."

${ }^{317}$ Muller, "Political Participation,"16

${ }^{318}$ Bosi and Della Porta, "Armed Groups."
} 
mobilisation of young Muslims in the US. ${ }^{319}$ A belief in the efficacy of conventional politics can even convince an individual to transition from violence to non-violence, "where engagement in the political process can substitute for violent terrorist engagement." 320

"If they won't listen to peaceful protest, then maybe they'll listen to a bomb" is a powerful (if flawed) narrative; for example, "aggressive state countermeasures directed against the Black Panther Party," including the characterization of Panthers as a 'Black nationalist/hate Group' in FBI security bulletins, ${ }^{321}$ "helped swell the ranks of the party's underground," 322 leading to the formation of the Black Liberation Army. The pejorative labelling of non-violent activists as 'extremists,' radicals,' and especially 'terrorists' is not only impolitic but potentially dangerous: this "may be seen as injustice thereby increasing group identification, and moving more individuals from activism to radicalism." 323 Repression that moves beyond mere vitriol-heavy-handed or indiscriminate protest policing, or example- is even riskier: many authors point to the shooting of civil rights protestors by British troops on "Bloody Sunday" as being the catalyst for decades of bloodshed in Northern Ireland. For both Basque

\footnotetext{
319 David Schwanzer, Charles Kurzman and Ebrahim Moosa, Anti-Terror Lessons of MuslimAmericans, Washington DC: National Institute of Justice (2010), in Bartlett and Miller, "The Edge."

${ }^{320}$ Max Taylor and John Horgan, "A Conceptual Framework for Addressing Psychological Process in the Development of the Terrorist," Terrorism and Political Violence 18(2006):595.

${ }^{221}$ William Rosenau, "Our Backs are Against The Wall: the Black Liberation Army and Domestic Terrorism in 1970s America,” Studies in Conflict and Terrorism 36 (2013): 178.

322 Ibid.179.

${ }^{323}$ Sophia Moskalenko and Clark McCauley, "Measuring Political Mobilization: the difference Between Activism and Radicalism," Terrorism and Political Violence 21 (2009): 257.
} 
separatists and Irish republicans, "state repression events affirmed their previous views and legitimized the final mobilisation into armed action," 324 while " 'actioncounteraction escalation' between state forces and movement activists"325 accounted for the emergence of the Weather Underground. Recognizing the legitimacy of non-violent activists, even those who oppose government policies, is perhaps the most effective countermeasure against terrorism bred of disenchantment with conventional politics.

In addition to providing evidence for the cooperation between protest routs and law enforcement/CT practitioners, the results of this plausibility probe also suggest that more nuanced protest policing should be sought. The realization that a protest practice is a habit of body and mind, and not a transitory state, enables practitioners to use restraint when confronting previously-peaceful protesters, confident that they will be likely met only with more non-violence. Futrell and Brents expand on this on an in-depth analysis of long-term protest at a U.S. Nuclear facility; ${ }^{326}$ their analysis shows that the post-9/11 CT climate has engendered a suspicion of illegal-but-peaceful protest around critical infrastructure sites in particular. This suspicion encourages a cycle of police repression-activist reaction-police violence-activist escalation, as described in

\footnotetext{
324 Bosi and Della Porta, “Armed Groups,” 372. 325 Eitan Alimi, "Relational Dynamics in Factional Adoption of Terrorist Tactics: A Comparative Perspective," Theoretical Sociology 40 (2011): 113, emphasis original. nuclear activism," American Behavioral Scientist 46, no.6 (2003): 745-765.
} 
Della Porta. ${ }^{327}$ To avoid such a scenario, "trust is the key:" 328 trust that law enforcement recognizes the peaceful nature of the protesters, and trust in the peaceful nature of the protester. Munson's theory shows that this trust can, and should, exist. Moreover, it can help to distinguish between protestors caught up in the 'on the spot' violence which can occur in contested protests, and activists for whom terroristic violence is a planned, strategic outcome.

\section{Conclusion}

While Munson's mobilisation process was not designed to explain mobilisation into terroristic violence, this plausibility probe has demonstrated that it holds promise in providing a visible, testable differentiation between individuals who may be mobilising into violence and those who are not; between those who have mobilised into non-violent activism round an issue, and those who have not, and; between those who should be monitored for signs of violent activity-including mobilising others into violence-and those who should not. Having been found to be useful, Munson's process has several advantages over existing understandings of terrorist mobilisation, the most notable being its observability: a life change such as a move, or the birth of a child, is much easier to recognize before the 'bang' than a more ephemeral 'feeling of alienation' or 'tendency towards sensation-seeking.' Moreover, Munson's process is easily comprehensible by those in the academic, policy-oriented and security fields,

\footnotetext{
327 Della Porta, “Social Movements.”

${ }^{328}$ Futrell and Brents, "Protest," 759.
} 
enabling it to flourish in what Sageman has called the 'dumbed down' or 'lowest common denominator' terrorism policy environment. ${ }^{329}$

Munson's process also provides answers as to the mechanics of mobilisation. For instance, while several theories of terrorist mobilisation identify 'cognitive openings' as times of vulnerability to terrorist recruitment, Munson identifies why life transition points are mobilisation periods: the physical and environmental changes that accompany these transitions bring individuals into contact with different people, and sometimes novel ideas. ${ }^{330}$ The importance of the 'turning point' criterion to more effective CT measures almost cannot be overstated: being able to determine who, among the many flocking to hear Abu Hamza's anti-Western invective at the Finsbury Park Mosque for example, is ripe for mobilisation, is infinitely more useful than the post hoc notation that four of those in attendance subsequently became the London bombers. ${ }^{3{ }^{1}}$ With these advantages, and with the is probe showing such promising results, it is hoped that further research into the will be undertaken, so

${ }^{229}$ Sageman, “Stagnation,"573.

${ }^{330}$ This process is further discussed, from a different methodological perspective, in Bouhana and Wikstrom.

${ }^{331}$ Aidan Kirby, “The London Bombers as 'Self Starters:' A Case Study in Indigenous Radicalization and the Emergence of Autonomous Cliques," Studies in Conflict and Terrorism 30 (2007): 420. The cleric is also alleged to have inspired several other terrorists, including Richard Reid and a 9/11 conspirator. http://www.telegraph.co.uk/news/worldnews/northamerica/usa/ 10841236/Abu-Hamza-trial-The-hate-preacher-of-Finsbury-Park-who-tried-to-plead-he-was-afriend-of-the-West.html What isn't discussed in these articles is the number of people who heard him preach between 1997 and 2003 (the mosque holds upwards of 2,000 people) who were not subsequently mobilised into terrorism; after the mosque had come to the security services' attention, it would have been useful to have as a sorting criterion Munson's turning point, to better target surveillance, if necessary. As it is, the mosque has taken pains to distance itself from Hamza, and from the unwelcome guilt by association that discussions of Islamic radicalisation like Kirby's inevitably bring. See http://www.independent.co.uk/news/uk/home-news/finsburypark-mosque-emerging-from-the-shadow-of-abu-hamza-942830o.html 
that Munson's theory can be more vigorously tested, to the benefit of both the terrorism studies and social movement disciplines. 


\section{Appendix 1: Interview Questionnaire}

\section{Beliefs}

Questionnaire \#2 Non-violent case subjects: Biographical and

Note: It is expected that many of these questions will be answered indirectly, in respondent's own narrative. Follow-up questions in italics to be asked as needed. Interview format is to be semi-structured, therefore many of these questions will serve more as interviewer prompts, to ensure continuity between subjects/interviews.

Verbal warning to participants: "Please refrain from revealing to me any information you might have concerning future violent or harmful activities, as I may be obliged to reveal such information to the police."

Verbal warning: "As well, for your own security please refrain from discussing in detail any illegal action for which you have not already been tried and convicted of."

Basic Biographical Information Brackets () indicate information to be omitted for privacy

1. (Name) Age, Sex, (Current residence,) Citizenship.

2. Partnered/Separated/Widowed/Single? Children? When did the above take place?

\section{Early Life}

1. (When and where were you born?)

2. Were/are your parents married, did you grow up with both of them? If divorced, when? Amicable? Step-parents?

3. Are your parents still living? If deceased, when/how?

4. What were your parents' occupations growing up? Steady work? Income? Self-described "class?"

5. Do/did you have any siblings? If deceased, when/how?

6. Extended family: were you close to your grandparents, aunts/uncles/cousins etc? Family conflict? Any bereavement in extended family of note? 
7. Describe where you grew up: did you move around, or stay in one house? Same friends and neighbours?

8. School: neighbourhood school? Standard program or "streamed"? Same group of friends all through? When did you change schools, i.e. high school, etc.? Did you ever have to leave or transfer to different school? Any interruptions in schooling due to behaviour, illness etc.? If so, when/what age?

9. Were you ever hospitalized/seriously ill as child/youth? Incarcerated or institutionalized, even briefly?

10. Did you have any contact with youth justice system, or child services? Petty crime, truancy, etc.? Foster care?

11. Were you involved in a faith or ethnic/national community growing up? Are you still? If not, when did you break with it?

Adolescence/Young Adulthood 1. What was the last year of public schooling you attended (before any post secondary.)

2. Did you have to change schools or districts for high school? Did your childhood peers accompany you?

3. What was high school like for you, academically? Socially? Activities or sports, music, etc? Politics? Intentions beyond high school-yours and your parents??

4. After school leaving/graduation: jobs? Travel? University? Where, with whom? Did your parents approve?

5. Romantic involvements: any serious? Who/when? Abusive/violent?

6. Job history: career? Unemployment? Strikes? Change of work locations, conflict with coworkers, etc.

7. Conflict with law-as youth, as adult, charges, convictions, imprisonments?

8. Military service: applied/accepted/denied/served?

\section{$\underline{\text { Activism }}$}

1. Were your parents/other family members politically active growing up? "around the dinner table" or participation in marches, etc. as a child? 
2. Did you share your general political beliefs with your parents? Do you now? If not, when did you diverge? Do your siblings/other family members still agree?

3. When did you begin to be politically active in your own right? Around what issues? How? (e.g. letters, leafletting, marches, etc.)

4. What and who were your introduction to this initial activism? If through someone else, describe their beliefs/activities? Your relationship with them?

5. Was this person/people involved in your subsequent activism? If no, why not? Falling out/divergence? When?

6. How and when did you first hear of "direct action?" From whom? What did you initially think of it? If/when did your feelings change?

9. How and when did you become aware of (BC Hydro/Litton Industries/Red Hot video, and the surrounding issues)? What engaged you about this issue?

10. Was there someone involved in introducing you to these issues? If so, who? Describe relationship.

11. Was this person involved in your subsequent activism?

12. What was it about this issue that engaged you? Why was it important?

13. What were your first actions around (the issue)? Subsequent?

14. Describe your activism around (this issue.)

15. What led to your deciding upon (said activism tactics) in regards to this issue? Had you considered direct or violent action? Did any of your peers? (This question is seeking to determine whether the respondent has ever had contact with individuals who have chosen violent protest tactics.)

16. Do you still consider yourself to be an activist? If so, what around? Describe your activity in general terms, omitting any details of violent or illegal activity. 


\section{Appendix 2: List of Interviewees}

1. "Martha," interviewed by telephone 18 November 2013. Member of 1980 os nonviolent group opposed to Litton Industries and the cruise missile.

2. "Peter," interviewed by telephone 23 October 2013. Member of non-violent groups opposed to nuclear war, now and in 1980 .

3. "Patricia," interviewed by telephone 11 December 2013. Member of nonviolent groups opposed to nuclear war, now and in 1980 .

4. "Alyssa," interviewed in person 7 May 2014. Member of non-violent charitable group concerned with environment education and awareness.

5. "Zaphod," interviewed in person 30 April 2104. Member of non-violent charitable group concerned with environmental issues, specifically green energy and climate change.

6. "Rupert," interviewed via Skype 9 May 2014. Employee of a UN-affiliated non-violent NGO dedicated to encouraging youth action on social issues, particularly environmental conservation.

7. "Janet," interviewed in person 15 April 2014. Member of non-violent environmental group and government liaison concerned with environmental issues.

8. "Eric," interviewed in person 27 March 2014. Member of non-violent group affiliated with an environmental NGO.

9. "Suzanne," interviewed by Skype 12 March 2014. Member of peaceful group opposed to Litton industries, as well as anti-nuclear activism in general.

10. "Christy," interviewed via telephone 16 April 2014. Member of several nonviolent anti-war and anti-poverty groups. 


\section{Appendix 3: List of sources for Violent case data}

1. Aly, Anne, and Jason-Leigh Streigher. "Examining the Role of Religion in Radicalization to Violent Islamist Extremism." Studies in Conflict \& Terrorism 35, no. 12 (2012): 849-62.

$n=1$; case history of Jack Roche, a convert involved in Islamist terrorism.

2. Berko, Anat, and Edna Erez. "Gender, Palestinian Women, and Terrorism: Women's Liberation or Oppression?” Studies in Conflict \& Terrorism 30, no. 6 (2007): 493-519.

3. . “'Ordinary People' and 'Death Work:' Palestinian Suicide Bombers as Victimizers and Victims." Violence and Victims 20, no. 6 (2005): 603-23.

Combined $n=16$; Interviews with persons convicted of terrorism-related offences in Israeli prisoners.

4. Horgan, John. Walking Away From Terrorism. London: Routledge, 2009.

$n=4$; Included are interviewed subjects from far-right, nationalist and Islamist violent groups.

5. Olsen, Jon. Roads To Militant Radicalization: DIIS Report 2009:12. Copenhagen, 2009

n=5; Author's criteria for inclusion was "people who were born and/or raised in European democracies and who, at a time of life in a group setting, planned and executed acts of politically motivated violence against representatives of the perceived enemy or with the goal of changing society as we know it."

6. Post, Jerrold. The Mind of the Terrorist. New York, NY: USA: Palgrave Macmillan, 2009.

$n=10$; Biographical profiles of terrorists from Islamist, ethno-nationalist and far-left groups included.

7. Vidino, Lorenzo. "The Buccinasco Pentiti: A Unique Case Study of Radicalization." Terrorism and Political Violence 23, no. 3 (2011): 398-418.

8. "The Hofstad Group: The New Face of Terrorist Networks in Europe." Studies in Conflict and Terrorism 30(2007): 579-592.

Combined n=4; Case studies of people living in Europe who participated in Islamist extremism. 
Other Subjects: Information drawn from multiple sources

"The Family," a loose cell of ELF/ALF-style militants who were responsible for a series of arsons and 'ecotage' attacks in the late 1990s. The persons with sufficient biographical information available to test Munson's theory:

Rebecca Rubin

Daniel McGowan

Joyanna Zacher

Chelsea Dawn Zerlach

Suzanne Savoie

Briana Waters

$(\mathrm{n}=6)$

"Direct Action," Canadian terrorist group. Individuals with sufficient information available to test theory:

Anne Hansen

Gerry Hannah

Juliet Belmas

$(\mathrm{n}=3)$ 


\section{Bibliography}

Abrahms, Max. "What Terrorists Really Want: Terrorist Motives and Counterterrorism Strategy" International Security 32, no. 4 (2008): $78-$ 105 .

Ackerman, Gary. "Beyond Arson? A Threat Assessment of the Earth Liberation Front." Terrorism and Political Violence 15, no. 4 (2003): 143-70.

Alimi, Eitan. "Relational Dynamics in Factional Adoption of Terrorist Tactics: A Comparative Perspective.” Theoretical Sociology 40 (2011): 95-118.

Alonso, Regelio. The IRA and Armed Struggle. Routledge, 2006.

Altier, Mary Beth, John Horgan, and Christian Thoroughgood. "In Their Own Words? Methodological Considerations in the Analysis of Terrorist Autobiographies." Journal of Strategic Security 5, no. 4 (2012): 85-98.

Aly, Anne, and Jason-Leigh Streigher. "Examining the Role of Religion in Radicalization to Violent Islamist Extremism." Studies in Conflict \& Terrorism 35, no. 12 (2012): 849-62.

Bakker, Edwin. Jihadi terrorists in Europe. The Hague: Cliengendael (2006).

Barrett, Robert. "Interviews with Killers: Six Types of Combatants and Their Motivations For Joining Deadly Groups." Studies in Conflict \& Terrorism 34, no. 10 (2011): 749-64.

Bartlett, Jamie, and Carl Miller. "The Edge of Violence: Towards Telling the Difference Between Violent and Non-Violent Radicalization." Terrorism and Political Violence 24, no. 1 (2012): 1-21.

Baumann, Michael "Bommi." How It All Began. 2nd ed. Vancouver: Arsenal Pulp, 2000.

Bean, Clive. "Participation and Political Protest: A Model with Australian Evidence.” Political Behavior 13, no. 3 (1991): 253-83.

Benford, Robert D., and David A. Snow. "Framing processes and social movements: An overview and assessment." Annual review of sociology (2000): 611-639. 
Berko, Anat, and Edna Erez. "Gender, Palestinian Women, and Terrorism: Women's Liberation or Oppression?” Studies in Conflict \& Terrorism 30, no. 6 (2007): 493-519.

“'Ordinary People' and 'Death Work:' Palestinian Suicide Bombers as

Victimizers and Victims." Violence and Victims 20, no. 6 (2005): 603-23.

Berrebi, Claude. "Evidence about the link between education, poverty and terrorism among Palestinians." Peace Economics, Peace Science and Public Policy 13, no. 1 (2007).

Blazak, Randy. "White Boys to Terrorist Men." American Behavioral Scientist 44, no. 6 (2001): 982-1000.

Borum, Randy. "Radicalization into Violent Extremism I: A Review of Social Science Theories." Journal of Strategic Security 4, no. 4 (2011): 7-36.

"Radicalization into Violent Extremism II: A Review of Conceptual Models and Empirical Research.” Journal of Strategic Security 4, no. 4 (2011): 37-62.

Borum, Randy, and Chuck Tilby. "Anarchist Direct Actions: A Challenge for Law Enforcement." Studies in Conflict \& Terrorism 28 (2005): 201-23.

Bosi, Lorenzo, and Donatella della Porta. "Micro-Mobilization into Armed Groups: Ideological, Instrumental and Solidaristic Paths." Qualitative Sociology 35 (2012): 361-83.

Bouhana, Noemie, and Per-Olof Wikstrom. Al Qa`ida-Infuenced Radicalisation: A Rapid Evidence Assessment Guided by Situational Action Theory. London, 2011.

Button, Mark, Tim John, and Nigel Brearley. "New Challenges in Public Order Policing: The Professionalisation of Environmental Protest and the Emergence of the Militant Environmental Activist." International Journal of the Sociology of Law 30 (2002): 17-32.

Cameron, James, and Shannon Nickerson. "Predictors of Protest Among Anti Globalization Demonstrators." Journal of Applied Social Psychology 39, no. 3 (2009): 734-61.

Carson, Jennifer Varriale, Gary LaFree, and Laura Dugan. "Terrorist and Non Terrorist Criminal Attacks by Radical Environmental and Animal Rights Groups in the United States, 1970-2007." Terrorism and Political Violence 24, no. 2 (April 2012): 295-319. 
Chenoweth, Erica. "Why Civil Resistance Works." International Security 33, no. 1 (2008): 7-44.

Chermak, Steven, Joshua Freilich, and Michael Suttmoeller. "The Organizational Dynamics of Far-Right Hate Groups in the United States: Comparing Violent to Nonviolent Organizations." Studies in Conflict \& Terrorism 36, no. 3 (March 2013): 193-218.

Chermak, Steven M., and Jeffrey Gruenewald. "The Media's Coverage of Domestic Terrorism.” Justice Quarterly 23, no. 4 (December 2006) 428-461.

Comrade Black. "Militant Feminism: An Explosive Interview with a KKKanadian Urban Guerrilla.” Earth First! Journal 30, no. 3( April 2010): 14-16.

Cottee, Simon, and Keith Hayward. "Terrorist (E)motives: The Existential Attractions of Terrorism.” Studies in Conflict \& Terrorism 34 (2011): 963-986.

Cragin, R. Kim. "Resisting Violent Extremism: A Conceptual Model for Non Radicalization." Terrorism and Political Violence 26, no. 2 (2014).

Crenshaw, Martha. Explaining Terrorism. London: Routledge, 2011. (1981): 381-419.

Dalgaard-Nielsen, Anja. "Violent Radicalization in Europe: What We Know and What We Do Not Know." Studies in Conflict \& Terrorism 33, no. 9 (2010): 797-814.

Dawson, Lorne. The Study of New Religious Groups and the process of Radicalization in Terrorist Groups. (DRDC CSS CR 2009-02) Ottawa: Defence Research and Development Canada Centre for Security Science, 2009.

. "The Study of New Religious Movements and the Radicalization of Homegrown Terrorists: Opening a Dialogue.” Terrorism and Political Violence 22, no. 1-21 (2010).

Della Porta, Donatella. Social Movements, Political Violence, and the State. New York: Cambridge University Press, 1995.

Della Porta, Donna, and Heinz-Gerhardt Haupt. "Patterns of Radicalization in Political Activism: An Introduction." Social Science History 36, no. 3 (2012): 311-320. 
Donovan, John, and Richard Timothy Coupe. "Animal Rights Extremism: Victimization, Investigation and Detection of a Campaign of Criminal Intimidation." European Journal of Criminology 10, no. 1 (2013): 113-32.

Eisinger, Peter K. "The conditions of protest behavior in American cities." The American Political Science Review (1973): 11-28.

Ericksen-Nepstad, Sharon, and Christian Smith. "Rethinking Recruitment to High-Risk/Cost Activism: The Case of Nicaragua Exchange." Mobilization 4, no. 1 (1999): 25-40.

Finkel, Steven E., Edward N. Muller, and Karl-Dieter Opp. "Personal influence, collective rationality, and mass political action." The American Political Science Review (1989): 885-903.

Florez-Morris, Mauricio. "Why Some Colombian Guerrilla Members Stayed Until Demobilization: A Micro-Sociological Case Study of Factors That Influenced Members' Commitment To Three Former Rebel Organizations." Terrorism and Political Violence 22, no. 2 (2010): 216-41.

Futrell, Robert, and Barbara Brents. "Protest as Terrorism?” American Behavioral Scientist 46, no. 6 (2003): 745-65.

George, A.L., and A. Bennett. Case Studies and Theory Development in the Social Sciences. Cambridge: MIT Press, 2005.

Gildea, Robert. "Utopia and Conflict in the Oral Testimonies of French 1968 Activists." Memory Studies 6, no. 1 (2013): 37-52.

Gill, Paul. "Suicide Bomber Pathways Among Islamic Militants.” Policing 2, no.4 (2008): 412-422

Gousse-Lessart, Anne-Sophie; Vallerand, Robert; Carbonneau, Noemie; Lafreniere, Marc-Andre. "The Role of Passion in Mainstream and Radical Behaviors: A Look at Environmental Activism.” Journal of Environmental Psychology 35 (2013): 18-29.

Hadley, John. "Animal Rights Extremism and the Terrorism Question.” Journal of Social Philosophy 40, no. 3 (2009): 363-78.

Hargan, John, and Suzanne Hansfrod-Bowles. "From Resistance to Activism: The Emergence and Persistence of Activism among American Vietnam War Resisters in Canada." Social Movement Studies 4, no. 3 (2005): 231-59. 
Hanna, P. "Using Internet Technologies (such as Skype) as a Research Medium: A Research Note.” Qualitative Research 12, no. 2 (2012): 239-42.

Hansen, Anne. Direct Action: Memoirs of An Urban Guerrilla. Toronto: Between The Lines, 2001.

Hoffman, Bruce. Inside Terrorism. New York: Columbia University Press, 2006.

Horgan, John. "The social and psychological characteristics of terrorism and terrorists." In Root causes of terrorism: Myths, reality, and ways forward, edited by Tore Bjoergo, 44-53. London: Routledge, 2005.

"From Profiles to Pathways and Roots to Routes: Perspectives from Psychology on Radicalization into Terrorism." Annals of the American Academy of Political and Social Science 618 (2008): 80-94. . Walking Away From Terrorism. London: Routledge, 2009.

Jacques, Karen, and Paul J. Taylor. "Male and Female Suicide Bombers: Different Sexes, Different Reasons?” Studies in Conflict \& Terrorism 31, no. 4 (2008): 304-26.

Jasper, James M., and Jane Paulsen. "Recruiting Strangers and Friends: Moral Shocks and Social Networks in Animal Rights and Anti-Nuclear Protests." Social Problems 42, no. 4 (1995): 493-512.

Kelloway, Kevin, Lori Francis, Victor Catano, and Michael Teed. "Predicting Protest.” Basic and Applied Social Psychology 29, no. 1 (2007): 13-22.

Khosrokhavar, Farhad. Les nouveaux martyrs d'Allah. Paris: Flammarion, 2003.

King, Michael, and Donald Taylor. "The Radicalization of Homegrown Jihadists: A Review of Theoretical Models and Social Psychological Evidence. Terrorism and Political Violence 23, no. 4 (2011): 602-22.

Kirby, Aidan. “The London Bombers as 'Self Starters:' A Case Study in Indigenous Radicalization and the Emergence of Autonomous Cliques." Studies in Conflict and Terrorism 30 (2007): 415-428.

Klandermans, Bert. The Social Psychology of Protest. London: Wiley Blackwell, 1997.

Klandermans, Bert, and Dirk Oegema. "Potentials, networks, motivations, and barriers: Steps towards participation in social movements." American sociological review (1987): 519-531. 
Kleinmann, Scott Matthew. "Radicalization of homegrown sunni militants in the United States: Comparing converts and non-converts." Studies in Conflict and Terrorism 35, no. 4 (2012): 278.

Kundnani, Arun. 2012. "Radicalisation: The journey of a concept". Race \& Class 54, no. 2: 3-25.

Kydd, Andrew H. "Terrorism and Profiling." Terrorism and Political Violence 23, no. 3 (2011): 458-73.

Leader, Stephen, and Peter Probst. "The Earth Liberation Front and Environmental Terrorism." Terrorism and Political Violence 15, no. 4 (2003): $37-58$.

Lemieux, Anthony, and Victor Asal. "Grievance, Social Dominance Orientation and Authoritarianism in the Choice and Justification of Terror versus Protest." Dynamics of Asymmetric Conflict 3, no. 3 (2010): 194-207.

Levy, Jack. "Case Studies: Types, Designs and Logics of Inference.” Conflict Management and Peace Science 25, no. 1 (2008): 1-18.

Lim, Chaeyoon. "Mobilizing on the Margin: How Does Interpersonal Recruitment Affect Citizen Participation in Politics?” Social Science Research 39, no. 2 (2010): 341-55.

Linden, Annette and Bert Klandermans. "Stigmatization and Repression of the Extreme Right in the Netherlands.” Mobilization 11: 2006, pp. 141-157.

Lofland, John, and Rodney Stark. "Becoming a World-Saver: A Theory of Conversion to a Deviant Perspective." American Sociological Review 30, no. 6 (1965): 863-75.

Magourik, Justin. "Connecting A Thousand Points of Hatred." Studies in Conflict \& Terrorism 31 (2008): 327-49.

Malkki, Leena. "Survival on a Shoestring: The Symbionese Liberation Army Revisited.” Critical Studies on Terrorism 3, no. 2 (2010): 313-27.

Mastors, Elena, and Rhea Siers. "Omar al-Hammami: A Case Study in Radicalization.” Behavioral Sciences and the Law 32 (2014): 377-388.

McAdam, Douglas. "Recruitment to High-Cost Activism: The Case of 'Freedom Summer'." American Journal of Sociology 92, no.1 (1986): 64-90. 
McCauley, Clark, and Sophia Moskalenko. "Mechanisms of Political Radicalization: Pathways Toward Terrorism.” Terrorism and Political Violence 20, no. 3 (2008): 415-33.

McVeigh, Rory, and Christian Smith. "Who Protests in America." Sociological Forum 14, no. 4 (1999): 685-702.

Milla, Mirra Noor, Fatourochman and Djamaludin Ancok. "The impact of leader-follower interactions on the radicalization of terrorists: A case study of the Bali bombers.” Asian Journal of Social Psychology 16 (2013): 92-100.

Miller, DeMond Shondell, Jason David Rivera, and Joel C. Yelin. "Civil Liberties: The Line Dividing Environmental Protest and Ecoterrorists." Journal for the Study of Radicalism 2, no. 1 (2008): 109-23.

Miller, Gregory. "Terrorist Decision Making and the Deterrence Problem." Studies in Conflict \& Terrorism 36, no. 2 (2013): 132-51.

Moghaddam, Fathali M. "The Staircase to Terrorism: A Psychological Exploration." American Psychologist 60, no. 2 (2005): 161.

Monaghan, Jeffrey. "Making up 'Terror Identities': Security Intelligence, Canada's Integrated Threat Assessment Centre and Social Movement Suppression." Policing and Society 22, no. 2 (2012): 133-51.

Monaghan, Jeffrey, and Jeffrey Walby. "They Attacked the City': Security Intelligence, the Sociology of Protest Policing and the Anarchist Threat at the 2010 Toronto G20 Summit." Current Sociology 60, no. 5 (2012): 653-671.

Monaghan, Rachel. “Animal Rights and Violent Protest.” Terrorism and Political Violence 9, no. 4 (1997): 106-16.

. "Not Quite Terrorism: Animal Rights Extremism in the United Kingdom." Studies in Conflict \& Terrorism 36 (2013): 933-51.

. "Single-Issue Terrorism: A Neglected Phenomenon?" Studies in Conflict \& Terrorism 23 (2000): 255-65.

Moskalenko, Sophia. "Civilians into Warriors: Mechanisms of Mobilization in US Army Recruitment and Training." Dynamics of Asymmetric Conflict 3, no. 3 (2010): 248-68. 
Moskalenko, Sophia, and Clark McCauley. "Measuring Political Mobilization: The Distinction Between Activism and Radicalism." Terrorism and Political Violence 21, no. 2 (March 31, 2009): 239-60.

Muller, Edward, and Kenneth Godwin. "Democratic and Aggressive Political Participation: Estimation of a Nonrecursive Model." Political Behavior 6, no. 2 (1984): 129-46.

Muller, Edward N. "An Explanatory Model for Differing Types of Participation." European Journal of Political Research 10 (1982): 1-16.

Muller, Edward N., and Karl-Dieter Opp. "Rational choice and rebellious collective action." The American Political Science Review (1986): 471-488.

Munson, Ziad. The Making of Pro-Life Activists. Chicago: University of Chicago Press, 2008.

Myers, Daniel J. "The Diffusion of Collective Violence: Infectiousness, Susceptibility, and Mass Media Networks." American Journal of Sociology 106, no.1 (2000):178-208.

Nepstad, Sharon, and Christian Smith. "Rethinking Recruitment into High Risk Cost Activism: The Case of Nicaragua Exchange.” Mobilization: An International Quarterly 4, no. 1 (1999): 25-40.

Nesser, Peter. Jihad in Europe: A survey of the motivations for Sunni Islamist terrorism in post-millennium Europe (FFI/RAPPORT-2004/01146). Norwegian Defence Research Establishment (2004.)

Neville, Kate, and Leanne Smythe. CIR Working Paper No. 49: Environmental Activism or National Security Threat? Vancouver, 2009.

Neumann, Peter and Brooke Rogers, Recruitment and Mobilisation for the Islamic Militant Movement in Europe, Report for the European Commission (Directorate General Justice, Freedom and Security), 2007.

Novaks, Lesley, and Emma Wincup. Criminological Research. London: SAGE Publications, 2004.

Olsen, Jon. Roads To Militant Radicalization: DIIS Report 2009:12. Copenhagen, 2009. 
Opp, Karl-Dieter, Kate Burow-Auffarth, and Uwe Heinrichs. "Conditions for Conventional and Unconventional Political Participation: An Empirical Test of Economic and Sociological Hypotheses.” European Journal of Political Research 9 (1981): 147-68.

Orsini, Alessandro. Anatomy of the Red Brigades. Ithaca: Cornell University Press, 2011. . "Poverty, Ideology and Terrorism: The STAM Bond." Studies in Conflict \& Terrorism 35 (2012): 665-92.

Passy, Florence, and Marco Giugni. "Social Networks and Individual Participation: Explaining Differential Participation in Social Movements." Sociological Forum 16, no. 1 (2001): 123-53.

Petrie, Michelle. "A Research Note on the Determinants of Protest Participation: Examining Socialization and Biographical Availability.” Sociological Spectrum 24, no. 5 ( 2004): 553-74.

Pierce, Roy, and Philip Converse. "Attitudinal Sources of Protest Behavior in France: Differences Before and After Measurement.” Public Opinion Quarterly 54 (1990): 295-316.

Pisoiu, Daniela. "Coming to Believe 'Truths' About Islamist Radicalization in Europe." Terrorism and Political Violence 25 (2013): 246-63.

Pittel, Karen, and Dirk Rubbelke. "What Directs a Terrorist?" Defence and Peace Economics 17, no. 4 (2006): 311-28.

Post, Jerrold. The Mind of the Terrorist. New York, NY: USA: Palgrave Macmillan, 2009.

Post, Jerrold, Ehud Sprinzak, and Laurita Denny. "The Terrorists in Their Own Words: Interviews with 35 Incarcerated Middle Eastern Terrorists." Terrorism and Political Violence 15, no. 1 (2003): 171-84.

Precht, Tomas. Home grown terrorism and Islamist radicalisation in Europe: From conversion to terrorism. Copenhagen: Danish Ministry of Justice, 2007.

Richardson, Louise. What Terrorists Want. New York: Random House, 2006.

Rosenau, William. “'Our Backs Are Against the Wall': The Black Liberation Army and Domestic Terrorism in 1970 s America." Studies in Conflict \& Terrorism 36, no. 2 (2013): 176-92. 
Ross, Jeffrey Ian. "Attributes of Domestic Political Terrorism in Canada, 1960-1985." Terrorism 11 (1988): 213-33.

Sageman, Marc. Understanding Terror Networks. Philadelphia: University of Pennsylvania Press, 2004.

. Leaderless Jihad: Terror Networks in the Twenty-First Century. Philadelphia: University of Pennsylvania Press, 2008. . "A Strategy for Fighting International Islamic terrorists." Annals of the American Academy of Political Scientists 80 (2008): 223-231. . "The Stagnation in Terrorism Research." Terrorism and Political Violence 26, no. 4(2014): 565-580.

Schibley, Ayla Hammond. "Toward a Common Profile of Religious Terrorism: Some Psychosocial Determinants of Christian and Islamic Terrorists.” Police Practice and Research 7, no. 4 (September 2006): 275-92.

Schmid, Alex P. Radicalisation, De-Radicalisation, Counter-Radicalisation: A Conceptual Discussion and Literature Review. The Hague, The Netherlands, 2013.

Schussman, Alan, and Sarah Soule. "Process and Protest: Accounting for Individual Protest Participation.” Social Forces 84, no. 2 (2005): 1083 1108.

Sedgwick, Mark. "The Concept of Radicalization as a Source of Confusion." Terrorism and Political Violence 22, no. 4 (2010): 479-94.

Seegmiller, Beau. "Radicalized Margins: Eric Rudolph and Religious Violence." Terrorism and Political Violence 19, no. 4 (2007): 511-28.

Shaykhutdinov, Renat. "Education for Peace: Protest Strategies of Ethnic Resistance Movements." Journal of Peace Education 8, no. 2 (2011): 143 55 .

Silber, Mitchell D., Arvin Bhatt, and Senior Intelligence Analysts. Radicalization in the west: The homegrown threat. New York: Police Department, 2007.

Simone, Joseph Jr., Joshua D. Freilich, and Steven M. Chermak. "Surveying state police agencies about domestic terrorism and far-right extremists." University of Maryland Study of Terrorism and Responses to Terrorism (2008). 
Sinai, Joshua. "Radicalisation into Extremism and Terrorism." Intelligencer: Journal of US Intelligence Studies 19, no. 2 (2012).

Smith, Jacqueline Christine. "Radicalization of life scientists to terrorism." Ph.D. dissertation. ProQuest: UMI Dissertations Publishing (2011).

Smith, Rebecca. “'Ecoterrorism'?: A Critical Analysis of the Vilification of Radical Environmental Activists as Terrorists." Environmental Law 38 (2008): $537-76$.

Snow, David A., and Robert D. Benford. "Master frames and cycles of protest." In Frontiers in social movement theory, edited by Aldon D. Morris and Carol McClurg Mueller, 133-155. Philadelphia: Yale University Press, 1992.

Snow, David A., and Richard Machalek. "The sociology of conversion." Annual Review of Sociology (1984): 167-190.

Snow, David, Louise Zurcher, and Sheldon Ekland-Olson. "Social Networks and Social Movements: A Microstructural Approach to Differential Recruitment." American Sociological Review 45, no. 5 (1980): 787-801.

Somma, Nicolas. "How Do Voluntary Organizations Foster Protest?” Sociological Quarterly 51 (2010): 384-407.

. "How Strong Are Strong Ties? The Conditional Effectiveness of Strong Ties in Protest Recruitment Attempts." Sociological Perspectives 52, no. 3 (2009): 289-308.

Speckhard, Anne, and Khapta Ahkmedova. "The Making of a Martyr: Chechen Suicide Terrorism." Studies in Conflict \& Terrorism 29, no. 5 (August 2006): 429-92.

Spray, Sharon, and Laura Roselle. Research and Writing in International Relations. Boston: Longman, 2012.

Sullivan, Jessica R, and By Jessica R Sullivan. "Skype: An Appropriate Method of Data Collection for Qualitative Interviews ?” Qualitative Research 6, no. 1 (2013).

Taylor, Lewis. Shining Path: Guerrilla war in Peru's northern highlands, 1980-1997. Latin America Studies Volume 6. Liverpool: Liverpool University Press, 2006. 
Taylor, Max, and John Horgan. "A Conceptual Framework for Addressing Psychological Processes in the Development of the Terrorist." Terrorism and Political Violence 18 (2006): 585-601.

Vanderheiden, Steve. "Eco-Terrorism or Justified Resistance? Radical Environmentalism and the 'War on Terror." Politics \& Society 33, no. 3 (2005): 425-47.

"Radical Environmentalism in an Age of Antiterrorism." Environmental Politics 17, no. 2 (2008): 299-318.

Victoroff, Jeff. "The Mind of the Terrorist." The Journal of Conflict Resolution 49, no. 1 (2005): 3-42.

Vidino, Lorenzo. "The Buccinasco Pentiti: A Unique Case Study of Radicalization." Terrorism and Political Violence 23, no. 3 (2011): 398 418.

. "The Hofstad Group: The New Face of terrorist Networks in Europe." Studies in Conflict and Terrorism 30(2007): 579-592.

Viterna, Jocelyn S. "Pushed, Pulled and Persuaded: Explaining Women's Mobilization into the Salvadorean Guerrilla Army." American Journal of Sociology 112, no. 1 (2006): 1-45.

Vitiuk, Viktor. Leftist Terrorism. Moscow: Progress Publishers, 1984.

Wasmund, Klaus. "The Political Socialization of West German Terrorists." Peter Merkl, ed. Political Violence and Terrorism: Motifs and Motivations. San Francisco: University of California Press, 1986: 191-228.

Webb, Jennifer J, and Susan L Cutter. "The Geography of U . S . Terrorist Incidents , 1970 - 2004." Terrorism and Political Violence 21 (2009): 428-49.

Weine, Stevan, John Horgan, Cheryl Robertson, Sana Loue, Amir Mohamid, and Sahra Noor. "Community and Family Approaches to Combating the Radicalization and Recruitment of Somali-American Youth and Young Adults: A Psychosocial Approach.” Dynamics of Asymmetric Conflict 2, no. 3 (2009): 181-200.

White, J. R. "Political Eschatology: A Theology of Antigovernment Extremism." American Behavioral Scientist 44, no. 6 (2001): 937-56. 
White, Robert. "From Peaceful Protest to Guerrilla War: Micromobilization of the Provisional Irish Republican Army." American Journal of Sociology 94, no. 6 (1989): 1277-1302.

Wiktorowicz, Quintan. Radical Islam Rising: Muslim Extremism in the West. Maryland: Rowman and Littlefield, 2005.

Wilner, Alex, and Claire-Jehanne Dubouloz. "Homegrown Terrorism and Transformative Learning: An Interdisciplinary Approach to Understanding Radicalization." Global Change, Peace \& Security 22, no. 1 (2010): 33-51.

Wood, Reed M. “Does Political Radicalization Depend on Ideology?” UNC Chapel Hill Doctoral Dissertation, 2008.

Zirakzadeh, Cyrus Ernesto. "From Revolutionary Dreams to Organizational Fragmentation: Disputes over Violence within ETA and Sendero Luminoso." Terrorism and Political Violence 14, no. 4 (2002): 66-92. 